\title{
LEGAL, REGULATORY \& INSTITUTIONAL ISSUES FACING DISTRIBUTED RESOURCES DEVELOPMENT
}

\author{
Prepared for \\ The National Renewable Energy Laboratory \\ Central \& Southwest Services, Inc. \\ Cinergy Corp. \\ Florida Power Corp. \\ San Diego Gas \& Electric
}

Prepared by

Prime Contractor

John Nimmons \& Associates

John T. Nimmons, J.D.

Olympia, Washington

Subcontractors

Kelso Starrs \& Associates Thomas J. Starrs, J.D. Bellevue, Washington
Energy \& Environmental Economics Ren Orans, Ph.D. San Francisco, Califomia Joel Swisher, Ph.D., P.E. Boulder, Colorado
Awad \& Singer Joel Singer, M.A., J.D. Oakland, California 


\section{ACKNOWLEDGMENTS}

This work was made possible through the support and cooperation of the National Renewable Energy Laboratory (NREL), Central \& Southwest Services, Inc. (C\&SW), Cinergy Corp., Florida Power Corp., and San Diego Gas \& Electric (SDG\&E). The role of the US Department of Energy Office of Energy Efficiency and Renewable Energy, Office of Utility Technologies, in support of NREL's participation is also acknowledged and appreciated.

We are grateful for the personal support and editorial contributions of NREL's Lynn Coles and Larry Goldstein, C\&SW's Charles DeWitt, Cinergy's David Freeman, Florida Power's Patsy Baynard and Len Zyki, and SDG\&E's R. A. Figueroa. The project would never have gotten under way without the personal support and professional perseverance of Steve Chapel of the Electric Power Research Institute, whose understanding of the value of this kind of research and willingness to champion it helped inspire others to proceed with the project.

As prime contractor, John Nimmons \& Associates wishes to express personal appreciation to subcontractors Ren Orans and Joel Swisher, Joel Singer, and Tom Starrs, who labored diligently to research and write portions of the report addressing cost and rate unbundling under the FERC MegaNOPR, performance-based ratemaking, and antitrust issues, respectively. Special thanks are due to Tom Starrs, who began with a limited research assignment and performed it with such diligence, intelligence and good spirit that he became indispensable to the project and eventually contributed to major portions of the report.

\section{NOTICE}

This report was prepared by John Nimmons \& Associates, Inc., of Olympia, Washington, as prime contractor, with the support of subcontractors Kelso Starrs \& Associates, Energy \& Environmental Economics, Inc., and Awad \& Singer, Inc. It was prepared as an account of work sponsored by the National Renewable Energy Laboratory, Central \& Southwest Services, Inc., Cinergy Corp., Florida Power Corp. and San Diego Gas \& Electric Company.

The authors have made every effort to present current and accurate information useful for the purposes for which the report was prepared. However, the information presented is not in any way intended as legal advice, and should not be relied on for that purpose. Neither the sponsors nor the authors or nor any person acting on their behalf makes any warranty or representation, express or implied, with respect to the accuracy or completeness of the information contained in this report, nor assumes any liability with respect to the use of, or for damages resulting from the use of, any information, method or process described or disclosed in the report. 


\section{DISCLAIMER}

Portions of this document may be illegible in electronic image products. Images are produced from the best available original document. 


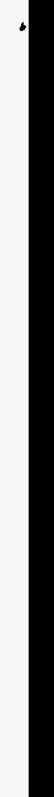




\section{DISCLAIMER}

This report was prepared as an account of work sponsored by an agency of the United States Government. Neither the United States Government nor any agency thereof, nor any of their employees, makes any warranty, express or implied, or assumes any legal liability or responsibility for the accuracy, completeness, or usefulness of any information, apparatus, product, or process disclosed, or represents that its use would not infringe privately owned rights. Reference herein to any specific commercial product, process, or service by trade name, trademark, manufacturer, or otherwise does not necessarily constitute or imply its endorsement, recommendation, or favoring by the United States Government or any agency thereof. The views and opinions of authors expressed herein do not necessarily state or reflect those of the United States Government or any agency thereof. 


\section{TABLE OF CONTENTS}

EXECUTIVE SUMMARY vi

1. INTRODUCTION

1.1 BACKGROUND. .1

1.2 PROJECT OBJECTIVES, STRUCTURE, AND SCOPE. .2

1.3 REPORT ORGANIZATION .3

2. OVERVIEW OF LEGAL AND REGULATORY FRAMEWORK

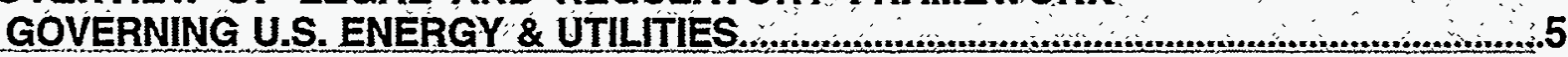

2.1 INTRODUCTION . .5

22 FEDERAL LAW, GENERALLY .6

23 STATELAW, GENERALLY. .6

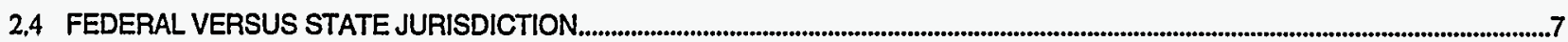

2.5 CONCLUSIONS REGARDING FEDERAL \& STATE LAW FRAMEWORK

\section{REGULATORY DEVELOPMENTS AFFECTING} THE VALUE OF DISTRIBUTED RESOURCES.

3.1 TRANSMISSION OPEN ACCESS \& UNBUNDLING OF SERVICES

3.1.1 Background.........................................................................................................................................................................................................................................13

3.1.2 Overview of FERC Open Access \& Unbundling Initiatives............................................................................................................15

3.1.3 Potential Market Structures, Unbundled Rate Forms, \& DR Impacts...................................................................................17

3.1.4 Example of Economic Incentives for DR Options.........................................................................................................................19

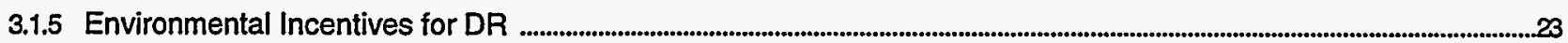

3.1.6 Conclusion Regarding Open Access \& Unbundling ...................................................................................................................................24

3.2 INCREASED USE OF PERFORMANCE-BASED RATEMAKING

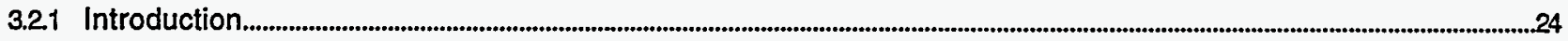

3.2.2 Traditional Ratemaking................................................................................................................................................................................................24

Cost of Service / Rate of Retum Regulation ..........................................................................................................................................25

Implications of Cost of Service/Rate of Retum Regulation for DR .......................................................................................................25

3.23 Performance-Based Ratemaking ...........................................................................................................................................................27

Introduction...........................

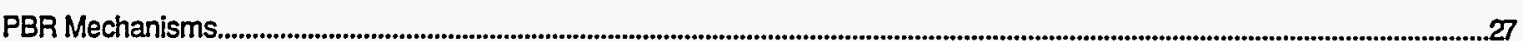

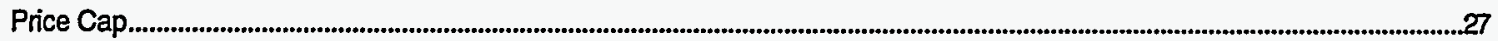

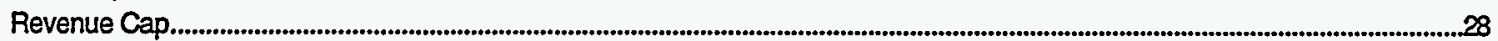

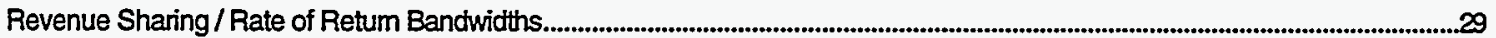

Additional Features: Performance Measures \& Benchmarking ................................................................................................29

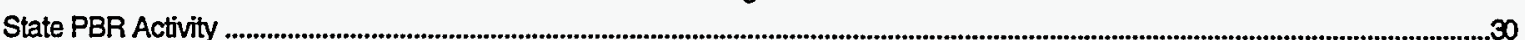

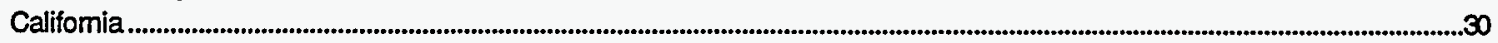

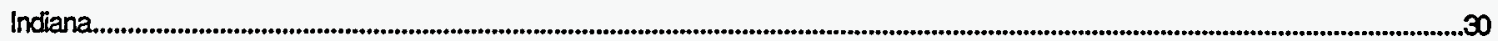




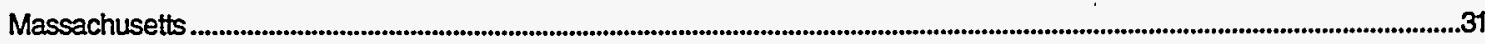

New York

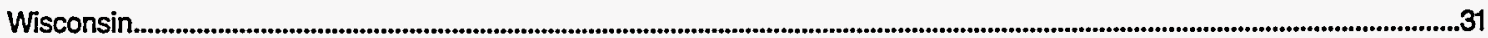

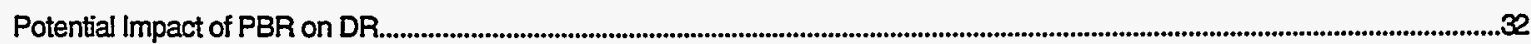

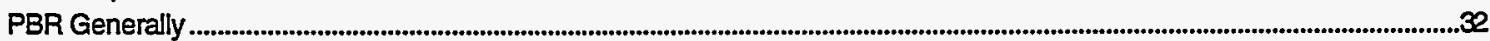

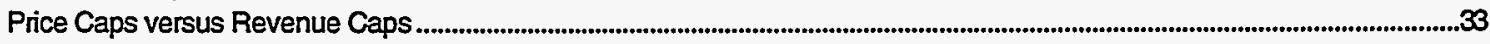

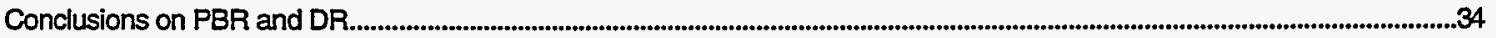

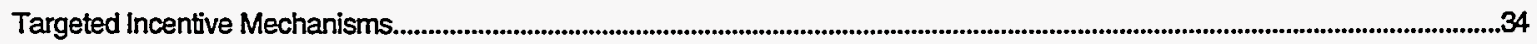

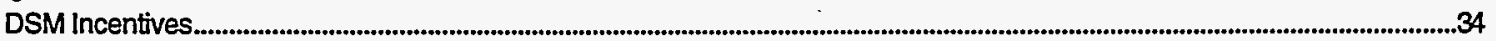

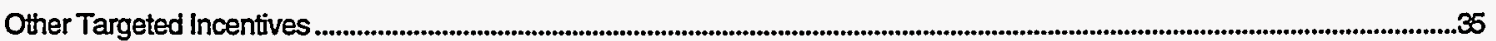

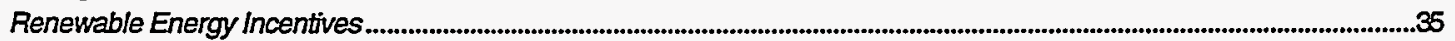

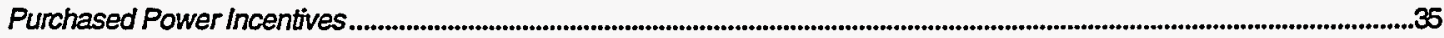

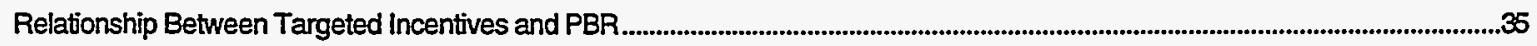

3.2.4 Conclusion Regarding Performance-Based Ratemaking ......................................................................................................................36

\section{ANTITRUST \& ANTICOMPETITIVE ISSUES FACING}

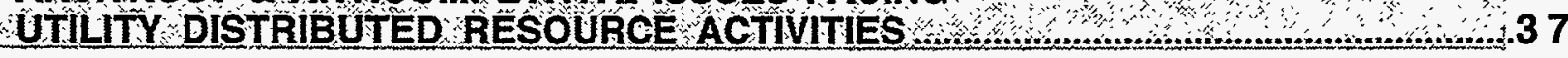

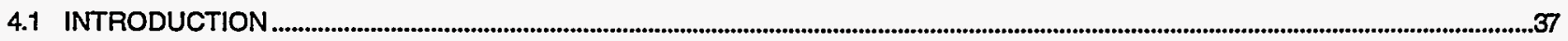

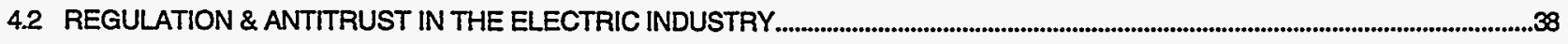

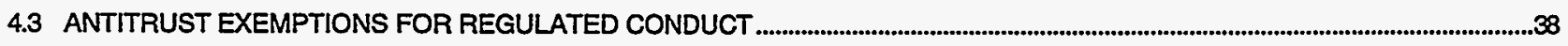

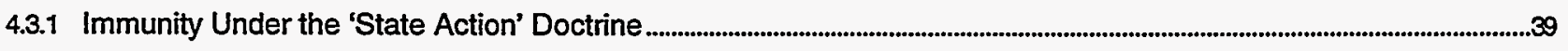

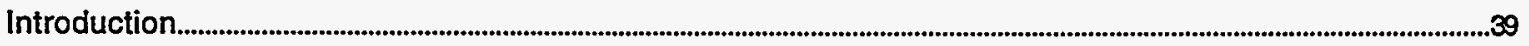

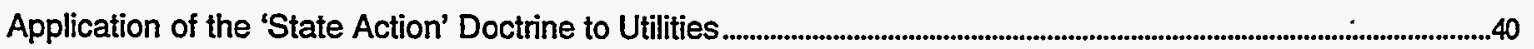

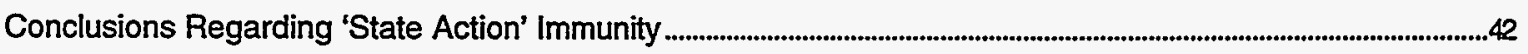

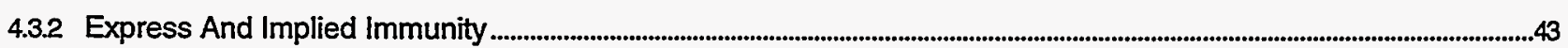

4.3.3 Immunity Under the 'Noerr-Pennington' Doctrine.................................................................................................................................45

4.4 WHERE ANTITRUST EXEMPTIONS DONT APPLY: LIABILITY THEORIES UNDER FEDERAL ANTITRUST LAW........................46

4.4.1 Monopolization And Attempted Monopolization .

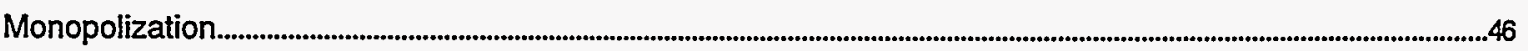

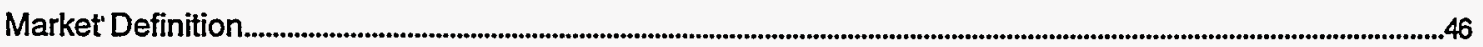

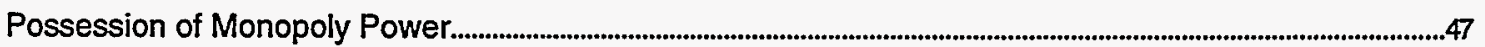

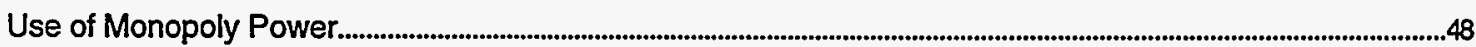

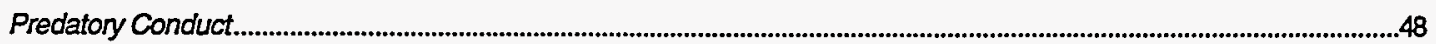

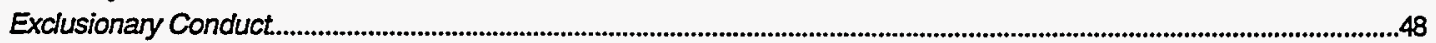

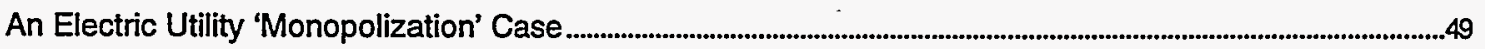

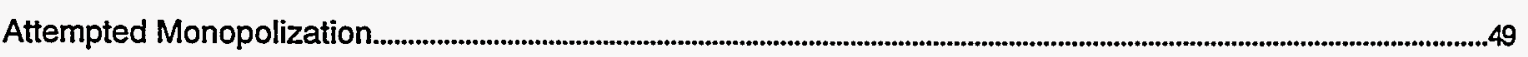

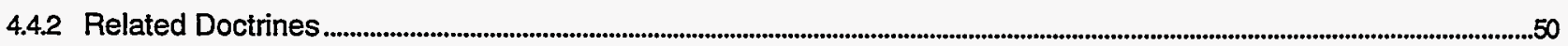

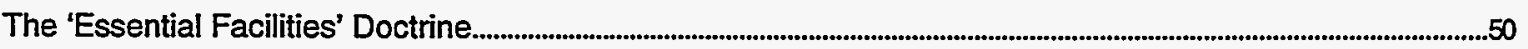

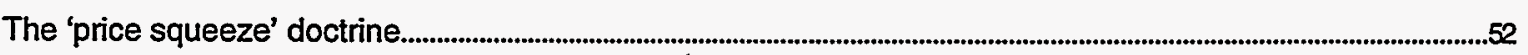

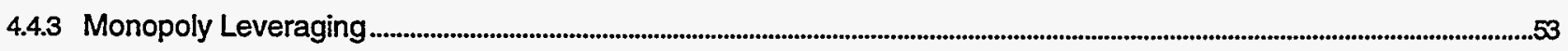

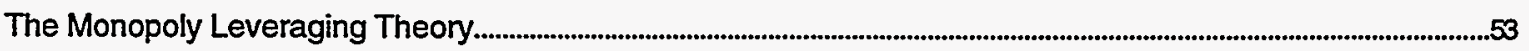

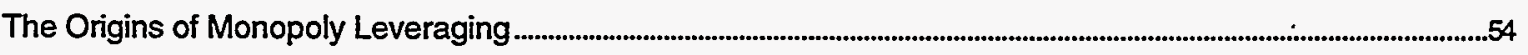

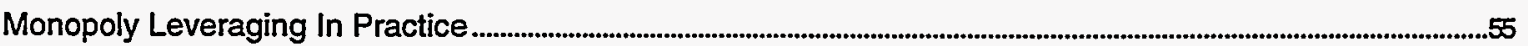


4.4.4 The "Tying" Doctrine Under The Sherman And Clayton Acts ......................................................................................................5

4.4.5 Unfair Competition and Unfair Trade Practices under the FTCA...........................................................................................................58

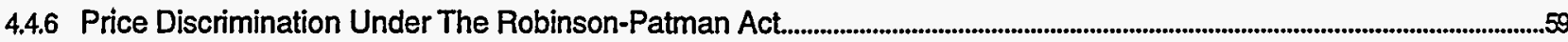

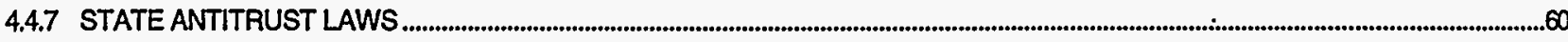

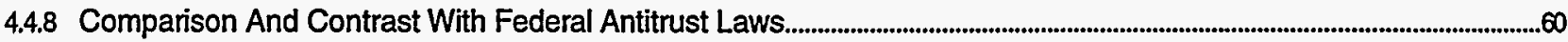

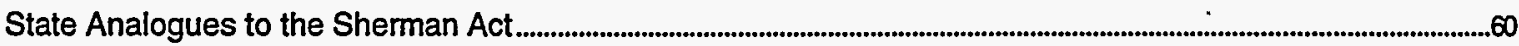

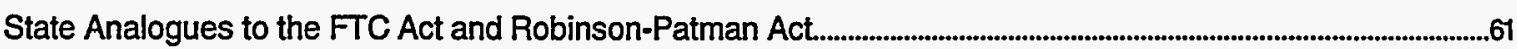

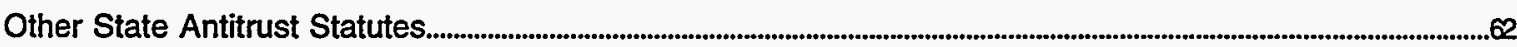

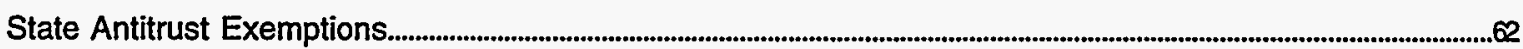

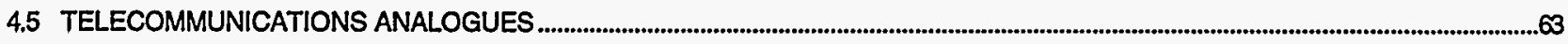

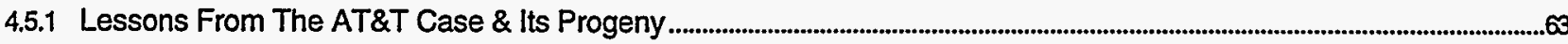

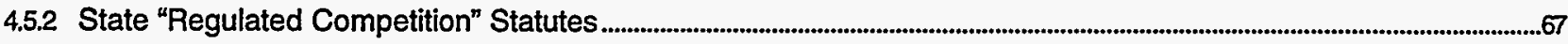

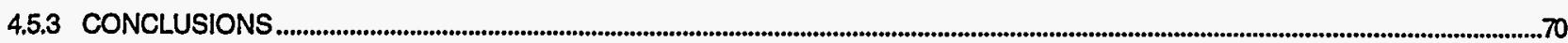

\section{STATE PUBLIC UTILITY LAWS AFFECTING IMPLEMENTATION}

OF DISTRIBUTED RESOURCES $\quad 1.1 \%$

5.1 STATE PUBLIC UTILITY REGULATION AND EXEMPTIONS.

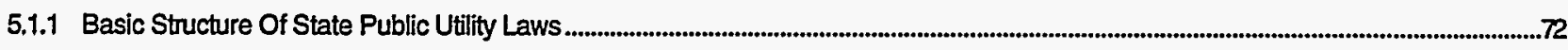

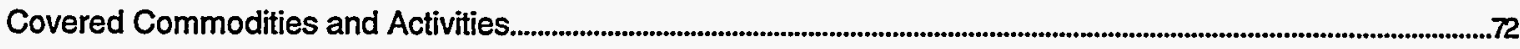

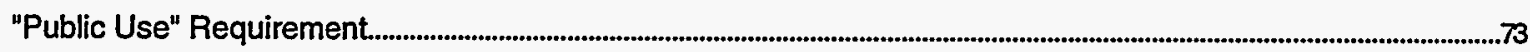

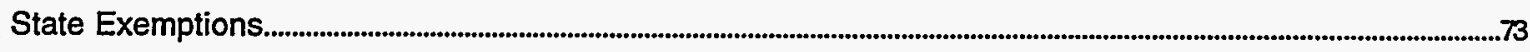

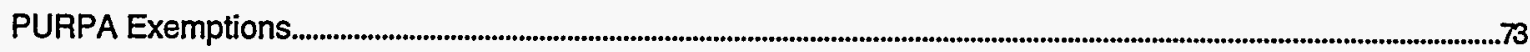

5.1.2 State Public Utility Laws Applied To Ownership \& Operation Of Distributed Resources....................................................74

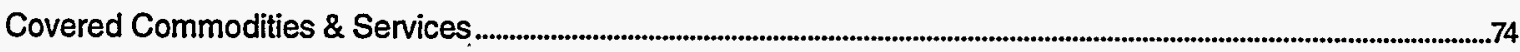

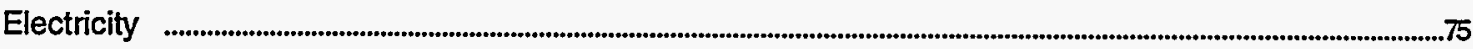

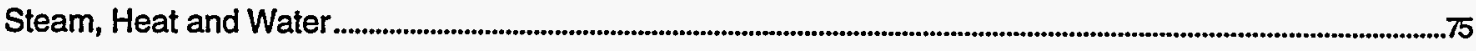

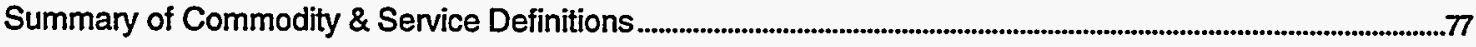

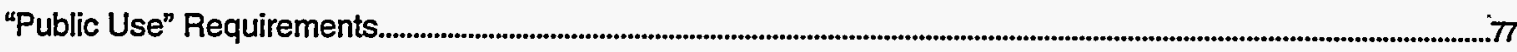

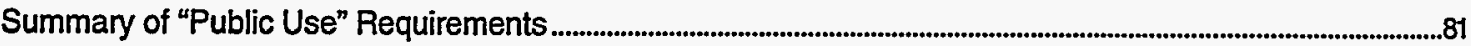

5.1.3 State Exemptions From Regulation.

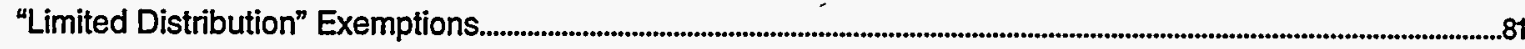

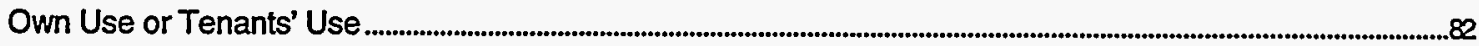

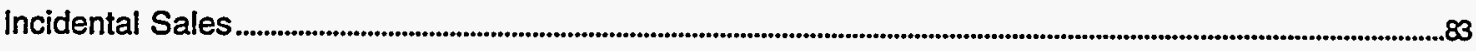

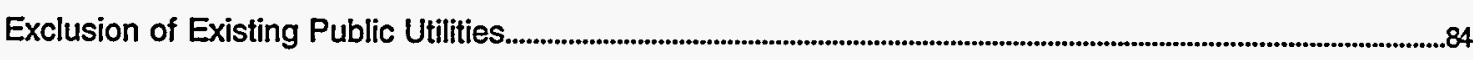

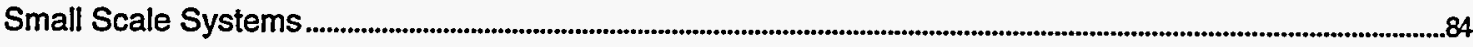

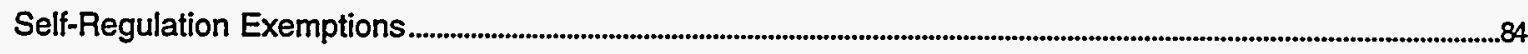

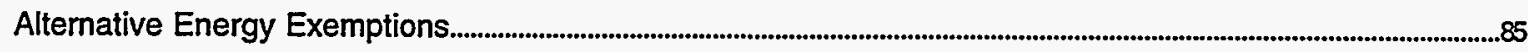

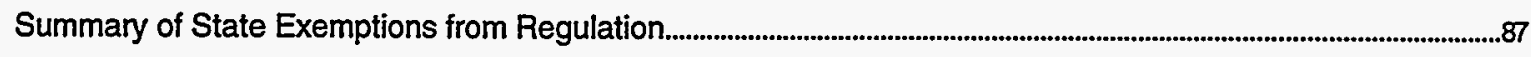


TABLE OF CONTENTS

5.2 STATE FACILITY SITING AND CERTIFICATION

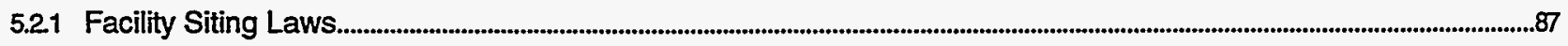

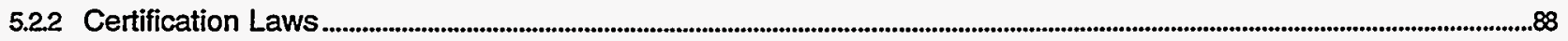

Certificates Of Public Convenience And Necessity...................................................................................................................................8

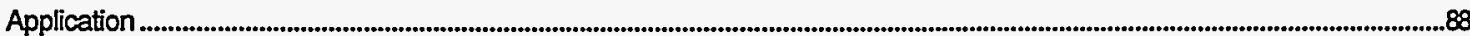

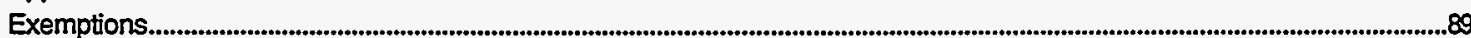

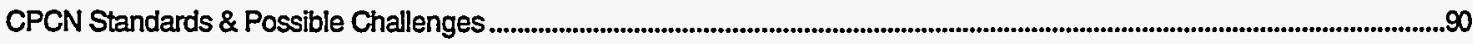

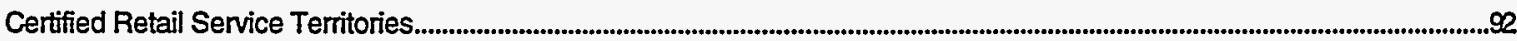

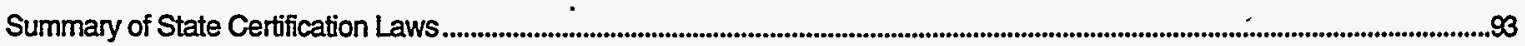

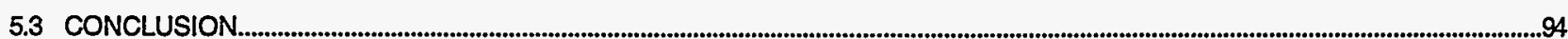

6. CONCLUSION

圆




\section{LIST OF FIGURES}

Figure 1. Structure of Laws, Regulations and Decisions Affecting Energy and Utility Activities ....................5

Figure 2. Federal vs. State Jurisdiction Over Unbundled Services........................................................11

Figure 3. Comparable Use of Transmission Services by Utilities and Third-Party Suppliers .........................15

Figure 4. Comparable Use of Ancillary Services by Utilities and Third-Parties.............................................16

Figure 5. Schematic Layout of Example Distribution Planning Area .........................................................21

\section{LIST OF TABLES}

Table 1. Electric Service Costs for Three Market Structure Scenarios ........................................................19

Table 2. DR Benefits As Seen From Each Market Participant's Perspective............................................20

Table 3. Present Value Costs of Alternative Distribution System and DR Options......................................22

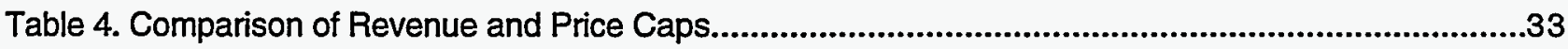

Table 5. Summary of Key Legal and Regulatory Topics and Their Importance for DR.................................96 


\section{INTRODUCTION}

This report describes legal, regulatory, and institutional considerations likely to shape the development and deployment of distributed resources. It is based on research co-sponsored by the National Renewable Energy Laboratory (NREL) and four investor-owned utilities (Central \& South West Services, Cinergy Corp., Florida Power Corporation, and San Diego Gas \& Electric Company). The research was performed between August 1995 and March 1996 by a team of four consulting firms experienced in energy and utility law, regulation, and economics. It is the survey phase of a project known as the Distributed Resources Institutional Analysis Project.

Key conclusions of the report are as follows:

- Legal and regulatory factors strongly influence the value of distributed resources, the allocation of benefits flowing from them, and the avenues available to utilities and others to pursue them.

- Unbundling of utility costs and rates resulting from new FERC requirements for nondiscriminatory transmission access and pricing, and from state restructuring proceedings, should enhance the value of DR in many situations and create new DR opportunities.

- Emerging performance-based ratemaking (PBR) can offer stronger incentives for utility distributed resource activities than traditional cost-of-service approaches, but actual impacts will depend on PBR implementation by individual utilities and state commissions.

- Antitrust and anticompetitive considerations will be key considerations for anyone considering DR implementation, and will fundamentally shape the roles and strategies available to utilities and their affiliates in DR markets.

- Where distributed resource facilities or their owners are subject to utility regulation, it will usually be by state commissions rather than the Federal Energy Regulatory Commission (FERC), unless the facility engages in wholesale electricity sales.

- Most state public utility laws defining entities and activities subject to regulation have not yet been changed to reflect competitive developments in the electric industry, and could result in state regulation of entities pursuing DR activities that are arguably competitive.

- Many distributed resource applications are below the size threshold for state facility siting laws, but may well be affected by laws requiring certification of utility facilities and services.

\section{Project Background \& Research Objective}

The distributed resources (DR) concept envisions that traditional utility central station generation, transmission, and distribution will increasingly be supplemented with small, decentralized or 'distributed' generation, storage, and demand-side management technologies. These include gas and diesel generators, wind turbines, photovoltaics and other renewables, fuel cells, batteries, and load management devices. Distributed facilities might be installed on customer premises, or at substations or other locations on the utility's distribution system. They will be strategically sited and operated to add value to the utility system beyond traditional energy and capacity. The added values that make DR attractive can include some combination of customer retention; reduced investment risk; deferred transmission and distribution (T\&D) investment; reduced T\&D losses; increased system reliability; local environmental benefits; overall system efficiencies; and site-specific economies. 
Studies addressing DR economics, evaluation, and planning have shown that DR can offer substantial, quantifiable benefits. The work reported here represents a first systematic look at legal, regulatory, and institutional factors that will influence whether those benefits can be realized in practice, who will capture them, and how DR business opportunities might best be realized. These factors are especially important because the DR concept departs radically from the central station natural monopoly paradigm on which traditional utility regulation is based, and it raises numerous issues traditionally on the periphery of utility activity. In addition, interest in DR has emerged just as federal and state utility law is abandoning many traditional monopoly concepts in favor of competitive electricity supply. These changes will affect both the value of DR and the avenues available to pursue it.

The objective of this research phase was to identify and describe basic elements of the legal and institutional framework for DR development that are likely to impact DR planning by utilities and others. As originally conceived, a second phase of work would assess the implications of the findings reported here for the development of utility business strategies under various evolving regulatory scenarios. Decisions whether to proceed with that work will likely be made by individual utilities as their needs dictate.

The report begins with a brief overview of the legal and regulatory framework that governs US energy and utility activities. It then reviews recent regulatory developments on transmission open access and incentive ratemaking which could fundamentally affect the value of DR to both utilities and energy customers. The next chapter assumes that DR will be valuable under some conditions, and explores antitrust and anticompetitive issues likely to shape utility participation in DR activities. Finally, the report examines traditional state utility law and regulation which - notwithstanding the current focus on competition and industry restructuring - will continue to govern the electric industry until it is changed. In each area, the report's primary objective is to begin to define key issues for DR - not to resolve them or apply them to individual utility circumstances at this stage, but to suggest what they are and which ones seem especially important. Key research issues and findings are summarized below.

\section{OVERVIEW OF LEGAL \& REGULATORY FRAMEWORK GOVERNING U.S. ENERGY AND UTILITIES}

Laws and regulations affecting energy and utilities cut across multiple levels of federal, state and local jurisdiction. They include federal statutes and federal administrative agency regulations and decisions, as well as federal and state court decisions interpreting these. They also include state legislation, state agency rules and decisions, and state court decisions interpreting both federal and state statutes and administrative rules. Finally (although not addressed in this report), they include local planning and zoning rules and decisions that affect energy facility siting and utility operations.

\section{Federal Law and Regulation}

Federal legislation and administrative regulations establish and implement national policy as to matters affecting interstate commerce, and they generally have nationwide application. Among federal sources of energy and utility law, recent Federal Power Act provisions requiring open transmission access and prohibiting undue discrimination, and the Federal Energy Regulatory Commission's (FERC) new rules implementing them, may have the most far-reaching implications for DR planning and strategy in years to come (see open access discussion below).

Federal antitrust laws, including the Sherman Act, Clayton Act, Robinson Patman Act, and Federal Trade Commission Act, also apply to utilities as to other industries. Their application to regulated industries presents unique and difficult legal issues, but they will increasingly impact utility activities in general and DR activities in particular as electric deregulation proceeds. Indeed, one of 
the key conclusions of this research is that the antitrust laws will substantially affect whether and how utilities and their affiliates can participate in DR markets. In this regard, Sherman Act cases addressing 'state action' antitrust immunity and liability under 'monopoly leveraging,' 'essential facilities' and related doctrines are especially instructive, as are cases dealing with the AT\&T divestiture and the restructuring of the Bell Operating Companies.

\section{State Law and Regulation}

Almost all states' statutes create public utility regulatory bodies analogous to the FERC, but responsible for regulating utilities located within the state and activities that affect state and local interests. These statutes establish regulatory commission jurisdiction, define 'public utilities' subject to regulation, and exempt certain entities and activities from such regulation. These public utility definitions and exemptions can significantly affect the status and treatment of DR facilities under existing regulatory regimes.

Many states also have energy facility siting and/or certification laws that establish criteria and procedures for siting individual utility facilities, or more generally for rendering public utility service. The research disclosed that existing state siting laws typically do not apply to facilities below 50 to 75 megawatts of capacity, so many DR facilities will not be subject to them.

Most states have their own statutes paralleling the federal antitrust and unfair competition laws, especially the Sherman Act and the Federal Trade Commission Act. These state enactments are generally similar. However, specific language and coverage varies distinctly from state to state, and the variations can make a difference in their significance for DR planning.

At the administrative level, state utility commissions responsible for economic regulation of investor-owned electric utilities typically discharge these responsibilities through cost-based, rate-ofreturn regulation. However, various forms of incentive regulation emerging as part of the move toward competition can be expected to affect the value of DR to utilities, and their reasons to pursue it (see discussion of performance-based ratemaking below).

\section{Federal vs. State Jurisdiction}

Issues of federal/state jurisdiction are complex, and jurisdictional demarcations are often uncertain. However, they can be important for $D R$, so the report reviews current law and agency interpretations in this area.

Generally speaking, the Federal Power Act establishes FERC jurisdiction over facilities used for transmission and/or wholesale sale of electricity in interstate commerce. Under the Federal Power Act and US Supreme Court decisions interpreting it, transmission and wholesale sales satisfy the 'interstate commerce' requirement if they employ facilities connected to a multi-state grid, which most utility facilities in the continental US do.

The Federal Power Act generally exempts from FERC jurisdiction facilities used only in intrastate commerce, or for generation or local distribution. The intrastate exemption has typically been applied only to utility facilities in Hawaii, Alaska, and parts of Texas that are not connected directly or indirectly to the interstate grid. The exemption for generation facilities has not been well defined by the Federal Power Act, the courts, or FERC. The authorities appear to distinguish between FERC's jurisdiction over 'facilities' and its jurisdiction over transactions that involve such facilities. One view is that FERC rate jurisdiction extends to agreements that govern any single ingredient of public utility rates for wholesale electric sales or transmission service, and that actions which by themselves are not jurisdictional may become so if they facilitate jurisdictional service (although FERC has been flexible in dealing with small generating facilities and those that are not otherwise public utilities). 
Apart from FERC jurisdiction, state regulatory jurisdiction usually attaches to private ownership or operation of generation facilities which provide retail service 'to the public' or 'for compensation.' Many states exempt at least some types of facilities employing cogeneration, renewables, or other preferred resources or service configurations.

The distinction between FERC-jurisdictional transmission and state-jurisdictional 'local distribution' is also uncertain. Courts have held that local distribution facilities are not defined by where their power comes from (i.e., it may come from out of state). In the context of unbundled transmission services, the FERC has stated that any public utility facilities used to deliver power in interstate commerce from a third-party supplier to a wholesale purchaser are jurisdictional - whether labeled 'transmission,' 'distribution,' or 'local distribution' - while any facilities used to deliver that power from the wholesaler to the end-user are local distribution facilities subject to state jurisdiction. However, facilities used to deliver power in interstate commerce from a third-party supplier directly to an end-user may include both FERC-jurisdictional transmission facilities and state-jurisdictional local distribution facilities, depending on whether they meet various 'indicia' outlined by FERC in its open access proceedings.

The Congress and the courts ultimately will resolve many of these issues. For DR purposes, it is probably safe to say that DR applications involving generation facilities, as well as storage and demand-side management, will be subject primarily to state regulatory jurisdiction. Those engaged in wholesale sales will remain subject to FERC jurisdiction (although FERC may defer to state regulators for small and 'nonutility' facilities), while those engaged only in 'local distribution' directly to endusers will be subject only to state jurisdiction.

Where federal legislation and FERC open access initiatives encouraging competition now seem likely to have their greatest impact on DR is not through direct FERC jurisdiction over individual DR facilities, but in the economic and business climate created by utility unbundling and wholesale wheeling. For this reason, the report summarizes the fundamental changes proposed by FERC in its open access proceedings, and suggests how they might affect the value of DR to utilities and others.

\section{REGULATORY DEVELOPMENTS AFFECTING THE VALUE OF DISTRIBUTED RESOURCES}

Threshold questions for many considering DR are whether it makes economic sense, and whether it can provide value for energy customers and competitive advantages for energy suppliers. Although these are ultimately economic questions, their answers are strongly influenced by law and regulation. Accordingly, the report examines recent legal and regulatory developments likely to affect the value of DR to energy customers and suppliers, and thus their interest in pursuing it. In particular, it focuses on the potential impacts of new FERC requirements for non-discriminatory open-access transmission to be achieved by 'unbundling' the costs of generation, transmission and distribution, and of recent initiatives by state utility commissions to replace traditional cost-based ratemaking with performance-based (or 'incentive') ratemaking ('PBR').

The report suggests that unbundling will create valuable opportunities for DR to compete with the various unbundled utility functions, and that different forms of unbundling are likely to induce different levels of DR applications. It also suggests that PBR can offer utilities more powerful incentives for $D R$ than traditional cost-of-service regulation, but that its actual impact on DR will depend greatly on how individual commissions and utilities choose to implement it.

\section{Transmission Open Access \& Unbundling}

The attractiveness and eventual market penetration of DR depends largely on the costs of DR compared to alternatives such as central station generation or grid expansion. This comparison is 
usually based on the incremental costs of utility options that could be avoided by replacing them with DR. Most utilities today use system-average costs in this calculation, but recent advances in determining avoided costs on an area- and time-specific basis have important implications for DR.

System-level utility costs are most sensitive to generation and bulk transmission costs. Areaand time-specific costs depend most on distribution and local transmission costs. For utilities with slow load growth, the latter costs can represent a large share of current investment needs. If utilities know their area- and time-specific costs, they will know where and when their costs are significantly higher than the system average. Selective use of DR (i.e., at the correct location and time) can be used to compete with high utility avoided cost applications, which allow more expensive measures and larger DR investments to be cost-effective.

Regulatory and institutional factors can pose economic barriers to DR market penetration. First, traditional cost of service regulation provides very little financial incentive for vertically integrated utilities to lower their costs of transmission and distribution (T\&D) service. Second, information on avoided costs by area and time has been available only to a few of the more innovative utilities; most still calculate only their system average $T \& D$ costs, making it difficult to observe the economic benefits of DR. Third, vertically integrated utilities and/or their regulators frequently oppose area-specific ratemaking for reasons of.equity and social policy, even though this practice would be economically efficient when the cost to serve customers varies across these dimensions.

The development of competitive power markets as proposed by FERC and in various state restructuring proceedings can be expected to result in the unbundling of both costs and rates. Vertical de-integration of utility functions into different functional entities creates opportunities for DR to compete with each unbundled function. Each new entity will then have its own incentive to price its service to reflect its actual incremental costs. Different forms of 'functional unbundling' under consideration by regulators can yield different levels of cost-effective DR applications. The report reviews three of these for illustrative purposes.

The first approach is functional separation of generation, transmission and distribution costs within existing vertically-integrated utilities, along the lines proposed by FERC. The second is structural separation of generation, transmission and distribution entities through corporate divestiture (not required by FERC). A third approach is to consolidate network operations into an independent system operator ('ISO') as adopted in the California Public Utilities Commission's December 1995 restructuring decision. The ISO is responsible for operating the network, purchasing network support services, settling imbalances, and creating information necessary to operate a financial market that will hedge price risks and trade transmission capacity. This ISO structure is fully compatible with open access and retail competition.

The report analyzes the three unbundled market structures and their resulting rates. In the functional unbundling scenario described in the report, DR may appear attractive as a means to defer imminent investments in local T\&D capacity expansion, but there are few other niches for DR. The structural unbundling scenario offers the same limited local IRP opportunities, and also the possibility that transmission network users would pursue DR investments in order to relieve high transmission costs caused by existing network congestion (particularly for generators seeking to remove transmission constraints perceived to limit their own sales). In the full unbundling scenario with retail access, local IRP opportunities would be replaced by full marginal cost-based price signals at both the wholesale and retail levels, creating incentives for generators, wholesale customers, RetailCo's, and even retail customers to invest in DR if network constraints drive their T\&D costs upward.

The report provides an example of economic incentives for DR options. In the example, incentive differences among the three market structures are most evident in the benefits that accrue to the customer and the distribution utility (or RetailCo) from a DR acquisition. For generators and 
transmission entities (PoolCo or ISO), the DR benefit is mostly its energy production value, which must compete with other larger-scale (and probably lower cost) generation options.

The report suggests that the market value of DR options depends on their net benefit to one of the potential investors in the market, not on their overall benefit to the system. In the first two unbundling scenarios at the wholesale level, the distribution utility or RetailCo perceives incentives only where regulators permit a greater return on $\mathrm{DR}$ options than on distribution capacity expansion. In the full retail access scenario, the RetailCo may see a wide range of energy and system-level capacity costs. If it does not have excess energy and transmission capacity contracts, hourly spot energy prices and area-specific transmission costs appear as potential DR benefits, and any distribution capacity credit will be an important component of DR benefits. In this scenario, customers could see fully unbundled rates based on area- and time-specific energy, system capacity, and distribution capacity costs, and would see the full distribution capacity credit as a benefit.

The report's discussion of open access and unbundling concludes that success in creating a competitive bulk power market and implementing light-handed regulation of grid systems may remove important institutional barriers to $\mathrm{DR}$ investment, mainly through unbundling of services, costs, and rates. To the extent that area- and time-specific costs are translated to rates, customers themselves will be encouraged to adopt cost-effective DR technologies.

\section{Performance-Based Ratemaking}

As open access and unbundling initiatives create new competitive opportunities for $D R$, performance-based ratemaking ('PBR') has the potential to translate these opportunities into financial gains for utilities that implement DR projects. As used here, PBR refers to regulatory approaches which use performance relative to a pre-established target to set rates, as distinct from traditional regulatory models which rely on cost to establish utility rates.

The report contrasts traditional cost-of-service ratemaking (which rewards utilities for prudent capital investment) with emerging performance-based ratemaking (designed to reward utilities for efficiency and productivity gains). The report first describes key characteristics of traditional costof-service regulation. It then describes various forms of broad-based PBR and recent state initiatives to adopt or implement them. Finally, it discusses more narrowly-targeted incentive mechanisms adopted in some jurisdictions for demand-side management, renewables, and purchased power. For each type of mechanism discussed, it assesses potential impacts on DR development.

The report suggests that cost-of-service ratemaking in today's high risk environment may appear to favor smaller, less risky DR investments over large central station generation plants. However, utilities often view $D R$ as alternatives to $T \& D$, and traditional regulation provides little incentive to substitute $\mathrm{DR}$ for $\mathrm{T} \& \mathrm{D}$ investment. Emerging performance-based regulatory mechanisms, on the other hand, generally favor DR investments to the extent that $D R$ can minimize costs or promote efficiency. However, not all commissions or utilities will adopt PBR mechanisms, and those that do may combine them with targeted incentives or other measures that diminish the DR incentives that 'pure' PBR could otherwise create. For these reasons, the report concludes that the overall impacts of PBR and targeted incentives on utility interest in pursuing DR will depend largely on the specifics of programs adopted by individual jurisdictions.

\section{ANTITRUST \& ANTICOMPETITIVE ISSUES FACING UTILITY DISTRIBUTED RESOURCE ACTIVITIES}

This chapter of the report focuses on the question of whether utilities will be free to participate in DR markets as they wish, or whether and to what extent antitrust and anticompetitive concerns may dictate the nature and form of their participation. 
Antitrust and anticompetitive issues arise from the very nature of distributed resources. By definition, these resources are not utility central station plants whose economies of scale, scope, or integration historically have justified natural monopoly treatment by legislators and regulators. For this reason, some have questioned whether regulated utilities should be involved in their development and deployment at all, or if they should, how their participation can be structured to prevent crosssubsidies from monopoly activities, or unfair use of monopoly assets to disadvantage competitors.

The report reviews principles of antitrust and anticompetitive law bearing on these issues, and their application to other situations similar to utility DR activities. It suggests that this body of law will play an increasingly important role in influencing utility conduct as the electric industry becomes more competitive, and that increased scrutiny is especially likely for utility DR activities because of the potential to use utility monopoly power in regulated markets to gain unfair advantage in competitive DR markets.

The primary antitrust law of interest here is the Sherman Act, which prohibits monopolization and attempted monopolization, and has been held by some courts to prohibit 'monopoly leveraging' - i.e., conduct by a monopolist in one market that confers an unwarranted competitive advantage in a second market. The report describes the application of this and other antitrust laws to regulated utilities. It first reviews exemptions from antitrust law that may be available for utility DR activities, and then examines liability theories that could be advanced where these exemptions are not available.

\section{Federal Antitrust Exemptions For Regulated Conduct}

'State Action' Immunity. Regulated utilities are sometimes immunized from antitrust liability if their conduct is authorized by statute or approved by regulators. However, this immunity has never been absolute, and its scope has been narrowed considerably in recent years.

The doctrine of 'state action' immunity exempts the actions of states acting in their sovereign capacity, and of private parties acting under state regulatory supervision, from federal antitrust scrutiny. It is highly relevant to utility participation in DR markets, because it bears on the question of the extent to which utilities, acting in furtherance of state legislative and regulatory policy, can use their substantial market power to competitive advantage in DR markets without violating federal antitrust laws.

Recent court decisions applying the state action doctrine have used the Midcal test to determine whether private conduct warrants antitrust immunity. This test requires that the challenged conduct be pursuant to 'clearly articulated' and 'affirmatively expressed' state policy, and that the state or its agencies 'actively supervise' the conduct in furtherance of that policy. The challenge for DR participants is to determine what kind of involvement by a public utility commission will constitute 'clear articulation' and 'active supervision' of utility DR activities that might appear to have anticompetitive elements.

The report discusses a number of cases that provide guidance on these questions. The seminal case addressing state action as it applies to regulated utilities is the US Supreme Court's 1976 decision in Cantor v. Detroit Edison Co., where a pharmacist who sold light bulbs at retail sued Detroit Edison over its free light bulb exchange program, charging the utility with using its monopoly power in electricity distribution to restrain competition in light bulb sales. The Cantor case and others cited in the report suggest that the state action doctrine is unlikely to immunize utility DR activities that are purely voluntarily, and that even in an industry subject to pervasive regulation, the courts will look at the character of the specific market in which anticompetitive conduct is alleged to determine whether immunity should apply. In markets where the state does not intend to supplant competition with regulation, incidental regulation will not be granted the same deference and immunity is unlikely. 
More generally, the report concludes that state action immunity is likely to protect utility activities that state legislators or regulators choose to encompass within the boundary of the monopoly franchise, and unlikely to protect conduct outside that boundary. The boundary will shift as restructuring proceeds, and will vary from state to state in any case. However, the trend towards greater competition is likely to shrink, rather than expand, the monopoly franchise, and many $D R$ markets are likely to be on the far side of that line. DR applications viewed primarily as local grid support rather than as generation are more likely than others to fall within the monopoly franchise boundary, since the distribution system is expected to remain part of the regulated monopoly under most restructuring scenarios. Whether immunity will be granted in particular situations will depend on state-specific law and case-specific facts.

Other Immunity Doctrines. In addition to state action immunity, the report reviews doctrines of 'express' and 'implied' immunity, which seek to resolve potential conflicts between federal regulation and the antitrust laws. It finds that the ultimate question is the same: whether the government intended for regulation to supplant competition (and therefore the antitrust laws, which protect competition) with respect to the challenged conduct. The report also discusses the 'NoerrPennington' doctrine, which immunizes efforts by businesses to solicit government action (including regulatory commission action) that has the effect of reducing competition. The report suggests that this doctrine may actually favor utility DR participation, since it permits utilities to actively seek a prominent role in commercializing DR technologies, even if the programs and policies they advocate benefit them at the expense of potential competitors providing DR products and services.

\section{Liability Theories Under Federal Antitrust Law}

If none of the exemptions just discussed applies, utilities may find themselves defending against allegations that they have violated federal antitrust laws. Accordingly, the report outlines substantive antitrust claims arising under each of the major federal antitrust statutes, emphasizing those most likely to arise in the context of utility DR activities.

Monopolization and Attempted Monopolization. As noted above, the most likely basis for challenging utility participation in DR markets is Section 2 of the Sherman Act, which prohibits monopolization, attempts to monopolize, and (in some jurisdictions) monopoly leveraging. The first two - monopolization and attempted monopolization - are well established as independent claims under Section 2 . The third and arguably the most relevant - monopoly leveraging - is a controversial theory that has been adopted by some courts and rejected by others. The report reviews all three, as well as variants known as the 'essential facilities' doctrine and the 'price squeeze' doctrine.

To be successful, monopolization claims must prove (1) possession of monopoly power in the relevant market; and (2) willful acquisition or maintenance of that power, as distinguished from growth as a consequence of a superior product, business acumen, or historic accident. Attempted monopolization claims must prove (1) a specific intent to monopolize a relevant market, (2) predatory or anticompetitive conduct, and (3) a dangerous probability of success. 'Attempt' claims tend to focus more on conduct and less on the existence of market power, but the Supreme Court has suggested that they still require some indication that monopoly power is present or immediately threatened. The report observes that both types of claims require a high threshold of proof and neither will be easy to establish as to utility participation in DR markets, at least until utilities play a larger role in those markets than they have to date.

Monopoly Leveraging. The theory of 'monopoly leveraging' could present more cause for concern among utilities considering DR activities. Monopoly leveraging has been defined as a monopolist's use of its power in its own market to control activities in another market. To succeed, monopoly leveraging claims usually must prove (1) monopoly power in a relevant market, (2) challenged activities in a defined second market, (3) use of monopoly power, as opposed to other 
advantages the monopolist enjoys by virtue of size, integration, etc., and (4) unwarranted competitive advantage in the leveraged market.

The last element is what primarily distinguishes monopoly leveraging from conventional monopolization and attempted monopolization claims under the Sherman Act. This element implies a broader and less rigorous standard of proof that may fall considerably short of what would be required to establish monopolization or attempted monopolization under court decisions discussed in the report. Whereas establishing monopoly power would typically require a showing of domination in the second market, establishing an 'unwarranted competitive advantage' would focus more on the utility's conduct than on the structure of the market, and a utility could be guilty of leveraging even with a minor share of the second market. For this reason, the monopoly leveraging theory could significantly expand antitrust exposure for utilities which choose to participate in DR markets.

The report notes that monopoly leveraging has been a controversial area of antitrust law, and federal court decisions are in conflict regarding its validity as an independent basis for a Sherman Act Section 2 violation. Some courts recognize the claim when the elements listed above are present. Others reason that monopoly leveraging is just a special case of monopolization or attempted monopolization and that there must still be a showing of monopoly power in the second market. However, even one of the leading cases that invoked this reasoning to reject monopoly leveraging as an independent ground of liability emphasized that its conclusion might well be different if the monopolist were a regulated monopolist. The report concludes that, until the courts' conflict over monopoly leveraging in general and leveraging by a regulated monopolist in particular are resolved, this area will remain in flux, and will warrant close attention by utilities pursuing $D R$ activities.

Essential Facilities. The report also discusses the 'essential facilities' doctrine, developed in a line of monopolization cases involving dominant firms that refuse to deal with competitors in order to create or maintain their monopoly position. The doctrine has important implications for utility DR activities because it limits utilities' ability to restrict access to essential utility facilities (arguably including the distribution system) when such access is sought by competing DR providers. The doctrine could be invoked by parties seeking to prevent integrated utilities from gaining monopoly power in downstream markets by denying or unfairly restricting potential competitors' access to those markets. The terms of access to these facilities may be established through the regulatory process, as with FERC rules requiring utilities to provide open-access tariffs for interstate transmission. But to the extent that FERC or state regulators either fail to address access issues or address them without adequately resolving antitrust concerns, the essential facilities doctrine could be another weapon in the arsenal of emerging competitors.

'Price Squeeze.' The 'price squeeze' doctrine is another Sherman Act Section 2 monopolization theory discussed in the report. In the electric industry, 'price squeeze' cases usually have involved a private, investor-owned utility that sells power to retail customers as well as to wholesale customers. In these cases, the wholesale customer (usually a municipal distribution utility) has complained that the wholesale prices it is charged are too high, relative to the prices charged to the selling utility's retail customers, to permit it to compete for those retail sales. The effect of this 'price squeeze' may be to discourage retail customers from locating in the municipal utility's service territory, or to discourage the municipal utility from expanding that territory. The 'price squeeze' doctrine could be important for utility participation in DR markets because under certain unbundled rate scenarios (illustrated in the report), some could argue that utilities will be in a position to structure their rates to discourage DR development by competitors. To date, neither the courts nor leading antitrust analysts have provided much guidance regarding the doctrine's implications for utility participation in unregulated markets, but this area bears watching in the future.

Tying Arrangements. Both the Sherman Act and the federal Clayton Act prohibit 'tying arrangements,' in which a seller requires that a customer wishing to purchase one product from him must also purchase another. A tying arrangement violates the Clayton act when the seller has a 
monopoly in the tying product or is restraining a substantial volume of commerce in the tied product, while such an arrangement violates the Sherman Act only when both these requirements are met. In either case, a utility initiative that appears to link a monopoly product or service with a competitive DR offering could be subject to a claim of unlawful tying. The report discusses circumstances where the Clayton Act might apply to $\mathrm{DR}$, and those where it would not.

Unfair Practices and Price Discrimination. The report also reviews the Federal Trade Commission Act ('FTCA', which broadly prohibits unfair methods of competition and unfair or deceptive acts or practices, but provides limited remedies), and the Robinson-Patman Act (which deals with price discrimination that may reduce competition or create a monopoly). As to the FTCA, the report concludes that the Federal Trade Commission could challenge utility DR activities under its broad 'unfair practices' prohibition, but has generally limited its review to Sherman and Clayton Act standards. As to Robinson-Patman price discrimination claims, the report notes that proof of cost-justification is a complete defense, but that cost-justifying price differentials can be challenging - and will become more so as utilities differentiate rates to respond to competitive pressures.

\section{State Antitrust Laws}

State Parallels to Federal Law. Most state antitrust laws are based on analogous federal statutes. They typically extend antitrust jurisdiction to encompass intrastate conduct that cannot be reached by federal statutes because federal jurisdiction is limited to actions affecting interstate commerce. However, they often differ from their federal equivalents in small but significant ways. The report briefly reviews state laws that parallel the Sherman Act by prohibiting unlawful contracts, combinations or conspiracies to monopolize, attempts to monopolize, and monopolization. It also reviews state unfair practices and price discrimination laws. These laws vary significantly from state to state, so the report does not attempt to generalize findings in this area.

State Antitrust Exemptions. Some states exempt anticompetitive conduct by utilities or, more generally, by regulated industries. The report reviews representative examples from California, Florida, Kentucky, Texas, Washington, and Wisconsin. Again, the nature and scope of these exemptions varies significantly from state to state, so generalizations are not attempted.

\section{Telecommunications Analogues}

The electric industry is not the first regulated industry to confront antitrust issues as it considers activities beyond its traditional franchised monopoly functions. Among the major regulated industries that have already faced similar issues, telecommunications offers especially revealing lessons for utilities considering DR activities. The report describes some of these issues and some important principles brought to bear on them in the telecommunications context.

The litigation that led to AT\&T's 1984 divestiture included many elements of interest to utilities considering $D R$ activities, so the report highlights some of these. It notes that the government's core claim against AT\&T was that it had used its regulated monopoly status to erect anticompetitive barriers to entry in potentially competitive markets, and that its anticompetitive behavior made economic sense only because it was operating under a regulatory system - similar to the one governing electric utilities today - whose imperfections rewarded such behavior. Specific government charges against AT\&T - all potentially relevant to utility DR activities - included:

- refusals to permit competitors to connect with its network;

- discriminatory practices designed to raise competitors' costs;

- failure to provide regulators with cost information adequate to determine the reasonableness of prices charged in competitive markets; and

- pricing without regard to actual costs in order to eliminate competition. 
The report also discusses parts of the AT\&T case addressing the question of separation of regulated operations from competitive ones. There the Federal Communications Commission had found that the Bell Operating Companies' monopoly power over local exchange bottlenecks gave them the incentive and ability to cross-subsidize competitive services through monopoly rates, and to hobble competitors with inferior network access. The Commission concluded that non-structural regulations on cost accounting and network practices alone could not preclude anticompetitive practices, so it ordered that competitive services be provided through legally separate and independent entities. The Commission's approach and the criteria it used to make this determination are outlined in the report.

Turning to more recent developments that may bear on utility DR evaluation, the report summarizes state legislation that establishes or authorizes new regulatory regimes for telecommunications. These statutes generally acknowledge and promote the benefits of competition. They permit telecommunications utilities to enter markets for competitive services, while prohibiting specific anticompetitive behavior. Most of them direct utility commissions to determine which services are competitive and which are not, and to adopt alternative forms of regulation befitting each. These laws do not apply directly to electric utilities, but are included to indicate directions that states could take in regulating electric industry activities that include arguably competitive DR elements (as Indiana already has).

\section{Conclusions on the Importance of Antitrust for DR Planning}

The report concludes that antitrust principles and their application by courts, commissions, and legislatures are extremely important for those considering DR implementation: they will fundamentally shape the roles available to utilities and affiliated entities, and the business strategies that make sense for those interested in DR development.

Immunity will be unlikely in many DR situations. Courts and regulators will seek to protect utility ratepayers against the use of monopoly assets to cross-subsidize competitive activities, and to protect competitive markets against the unfair effects of such abuses. Both concerns can give rise to antitrust claims, usually under the federal Sherman Act, but also under the other federal and state laws described in the report. Where courts have accepted the monopoly leveraging theory as an independent basis for liability, it could increase utility antitrust exposure. Even where they have not, its underlying principles may be invoked in regulatory proceedings to constrain utility DR activities. In any case, telecommunications litigation suggests that courts and regulators will respond to the use of monopoly power in a utility's core markets to erect barriers in competitive markets, by requiring strict separation of monopoly from competitive activities, at least through separate accounting, and perhaps through corporate divestiture.

\section{STATE PUBLIC UTILITY LAWS AFFECTING DR IMPLEMENTATION}

Legal and regulatory doctrines discussed to this point suggest that if particular DR activities can be characterized as competitive, they may need to be undertaken outside of the regulated utility. Utility management may also believe that some DR activities entail different and higher risks than conventional utility activities, and may seek to pursue them as unregulated, nonutility operations that can yield higher rewards for success.

This chapter observes that state public utility laws defining entities and activities subject to state regulation could dictate results quite at odds with these doctrines favoring separation from the regulated utility, and could result in commission regulation of entities pursuing DR activities that are arguably competitive. These state laws remain in force in most states and will continue to govern until legislatures replace them with new regulatory regimes, notwithstanding current restructuring discussions by state regulatory commissions. They are especially relevant to DR facilities located on customer sites, and those furnishing energy offsite to someone other than the facility owner. 
Other state laws of interest to DR address energy facility siting, and certification of facilities, services, territories, and/or environmental compliance, all of which the report briefly reviews.

\section{State Public Utility Regulation And Exemptions}

Basic Structure. The basic structure of traditional state public utility laws is quite similar from state to state. However, specific state provisions differ in ways that can significantly affect DR planning. The report presents examples to illustrate typical state approaches and the kinds of issues they raise. Since there are few laws addressed to 'distributed resources' per se at this point, the report focuses on laws relating to specific resources and service configurations under consideration for DR applications.

Almost all states have statutes defining 'public utilities' or 'public service companies' subject to state utility commission jurisdiction. These definitions typically specify the types of commodities (electricity, gas, heat, water, etc.); the types of activities (production, generation, transmission, distribution, delivery, sale, etc.); and/or the types of entities (electric corporations, gas corporations, etc.) to which public utility status may attach.

Supplying one of the specified commodities or engaging in one of the specified activities will not necessarily subject the supplier to regulation as a public utility. Most state definitions and many court decisions additionally require that the commodity or service be offered 'to the public' or 'for public use' (or in the words of some statutes, 'for hire' or 'for compensation'). The question of what constitutes 'public' as distinguished from 'private' service rarely arises for conventional centralized utilities, whose service to thousands or millions of customers over wide geographic areas is so clearly 'public' that it requires no analysis. However, the question can be critical for DR providers considering distributing some or all of their electricity and/or cogenerated heat to more limited groups of retail customers (such as shopping center or industrial park occupants, residential apartments or condominiums, etc.) under novel service arrangements. The report reviews court and commission decisions on this subject, and notes considerable variation among the states.

Where a covered commodity or activity is supplied 'to the public' or performed 'for public use' the supplier will be subject to regulation as a public utility, zmless some other provision of law exempts it. Exemption provisions of interest for DR are noted below and discussed in some detail in the report.

Covered Commodities \& Services. Among the various commodities and services covered by state 'public utility' definitions, the ones most relevant to DR activities are those which arguably include DR outputs that might be exported from the facility - primarily electricity, but also steam, heat, or water in the case of cogeneration facilities. The report finds that state law definitions of these commodities and services (and state 'ownership or control' requirements as to facilities that provide them) are generally similar, but individual state variations can be important in determining regulatory status. Electricity sales usually do not raise problems of definition, but steam or hot water sales from cogeneration facilities may. The report presents examples of court and commission decisions addressing these issues.

'Public Use' Requirements. The question presented by 'public use' requirements is whether any retail distribution of electricity and/or heat to persons other than the facility's owners or operators will be characterized as 'private' transactions, or as 'public' service resulting in regulated utility status. The report suggests that the answer to this question will often determine the regulatory status of individual DR facilities supplying uses other than, or in addition to, the grid.

In general, 'public use' has been interpreted to mean service to, or readiness to serve, an indefinite public, or a dedication of products or services to the public as a class, as distinct from 
service which is essentially private in nature. However, these general formulations rarely provide adequate guidance for distinguishing private from public uses. In applying them to specific factual situations, state courts and commissions usually look at a variety of factors, including:

- the number of customers served;

- the relationship between the supplier and its customers;

- the relationship between the utility services provided and any other business of the supplier, including whether separate charges are levied for the services; and

- whether the services are provided solely through private property, or involve the use of public rights of way.

Courts often state that all of these factors (and sometimes others) are relevant to determining 'public use', and that no single one of them is controling. Thus the determination tends to involve a good deal of judicial or commission discretion, and its outcome in individual cases is not always predictable. This is especially true for limited distribution configurations such as shopping centers, office parks, residential subdivisions or similar applications which some DR facilities might serve.

State Exemptions From Regulation. If DR owner/operators desire to supply retail electricity (and/or steam or hot water) from facilities covered by state utility definitions in situations considered 'public uses,' they will be subject to state regulation absent some exemption.

Exemptions are usually statutory, but may also be the product of administrative or judicial decisions. The research reveals that they generally fall into three categories:

- 'limited distribution' situations, which are essentially refinements and codifications of the 'public use' doctrine;

- self-regulated entities such as municipal corporations and cooperative associations, which are thought to be adequately supervised and controlled by those they serve; and

- alternative energy facilities which advance state policy encouraging energy efficiency, resource diversity, and environmental improvements.

'Limited distribution' exemptions relevant to DR commonly include service for the producer's own use and that of its tenants and/or employees, and not for resale to others. This exemption is often, although not always, limited to service provided solely on or through private property. A number of states also exempt sales incidental to the supplier's main business and/or sales of surplus production exceeding the supplier's onsite needs.

'Self-regulation' exemptions apply primarily to municipal or other publicly-owned utilities, and to cooperatives, mutual water companies and non-profit entities controlled by their members. The report suggests that they may be more relevant to identifying DR markets than to structuring utility DR projects, on the theory that public or non-profit entities that can benefit from them may be more receptive than others to owning and operating DR and distributing DR outputs.

'Alternative energy' exemptions usually focus on cogeneration and/or renewable resource facilities. The statutes vary considerably in their approaches and coverage, and may include either full or partial regulatory exemptions for such facilities and their owner/operators. For entities considering DR activities using alternative resources, these exemptions may provide the broadest and most flexible avenues for structuring unregulated DR ventures. The report reviews a number of them and highlights variations that may be of interest for $D R$.

The report notes that statutory exemptions sometimes exclude existing public utilities by limiting their coverage to persons or corporations 'not otherwise a public utility'. The intention 
seems to be to ensure that other activities of existing regulated utilities will not be exempted by reason of engaging in activities which would be exempt if others conducted them, but the effect could be to preclude utilities from conducting some DR activities as unregulated operations within their existing structure, even though carefully segregated from regulated functions.

The report concludes that the kinds of exemption provisions just outlined remain good law in most states today, notwithstanding moves toward a more competitive electricity environment. Some, like the 'own use/tenants' and 'incidental sales' exemptions, can be useful for specific projects that fall within them, but are not likely to create general markets or support widespread unregulated DR activities. Others, like those for publicly and cooperatively-owned utilities, may be of interest chiefly as indicators of potential DR markets. The most promising exemptions for DR may be those enacted to encourage cogeneration and other alternative energy production. They are likely to be broader than some other exemptions, and more focused on the specific needs of DR development. However, their scope varies considerably from state to state: as enacted, some may not benefit conventional public utilities, and some may not cover all generation configurations of interest to DR proponents. Those willing to take the initiative here may have opportunities to educate legislators and regulators to support DR incentives that could benefit DR investors, utility ratepayers, and the general public alike.

Overall, the report finds that state law sometimes affords considerable flexibility to structure DR projects in ways that either invite or avoid regulation (for example, through the choice of resources and/or customers, the scope of distribution, the nature of contractual arrangements between the supplier and its customers, etc.) Thus it is important to carefully analyze individual laws governing specific DR facilities and service configurations to ensure desired regulatory outcomes.

\section{State Facility Siting And Certification}

The report reviews the potential application to DR facilities of state laws governing energy facility siting, certificates of public convenience and necessity, and related certification procedures designed to avoid duplication of service and allocate retail service territories. These siting and certification laws are not always distinct: they deal with similar subjects, and what some states call facility siting others refer to as certification. In general, however, facility siting laws focus on the facility itself, whereas certification laws often have a broader reach.

Energy Facility Siting. To assess the relevance of energy facility siting laws on DR, fourteen states were surveyed. Fewer than half had specific statutes governing electric facility siting per se, although a few others had statutes addressing environmental compatibility of such facilities. The siting laws generally require advance approval by a state agency for the construction of electric power facilities, variously defined. Most of the statutes exempt small facilities from their requirements, and some exempt facilities using renewable resources and/or qualifying cogeneration. Exemptions for 'small' facilities typically cover facilities under 50-75 MW or larger, so the report suggests that many DR facilities are likely to be exempt on that ground alone.

Certification. Certificates of public convenience and necessity (CPCNs) and certified territories are mechanisms by which many states control entry into markets for utility services. They are based on traditional natural monopoly theory, which sanctions exclusive franchised service territories in order to justify investment in centralized facilities capable of achieving economies of scale that benefit users of essential public services. Under this concept, regulatory agencies grant a utility the right to supply a particular commodity or service within a designated geographic territory. To protect that right and avoid duplication of services at consumer expense, regulators control market entry by granting or denying certification. Where certification is required, suppliers cannot lawfully build facilities, initiate service, or provide service in others' certificated areas without complying with statutory requirements. 
The research disclosed that some CPCN statutes apply only to public utilities, or only to some kinds of public utilities, proposing to build new facilities or modify existing ones. Other statutes are phrased more broadly to apply to those proposing to render 'public utility services' rather than, or in addition to, building or modifying physical facilities. Exemptions from CPCN requirements are often provided for certain types of construction or service extensions. Traditional examples include extensions within cities already served, or to areas contiguous to existing facilities not served by another utility, or to territories already served if necessary in the ordinary course of business. A recent Texas Public Utility Commission proposal would exempt small generation facilities relying exclusively on renewable resources, including 'distributed resources' as defined by the Commission.

Utilities considering DR activities within the regulated utility structure will need to determine whether their existing certification, if any, is broad enough to cover the types of DR facilities to be built or services to be offered. If not, or if the utility or others are considering pursuing DR activities through a separate nonutility entity, then they will need to determine whether the activities contemplated require certification under the particular language of its state's law - e.g., construction or operation of specified facilities or rendering of public utility services - or are exempt under the types of exemptions just mentioned.

Where CPCNs are required, states adopt their own standards for determining whether 'public convenience and necessity' will be served by new facilities or services. Historically, most CPCN applicants have been required to show that:

- there is adequate demand for the facility or service;

- they have sufficient capacity to meet that demand;

- suitable financing is available to complete their plans;

- their costs and proposed charges are reasonable; and

- the facility or service is needed and will not duplicate existing services.

The report observes that among these traditional standards for granting CPCNs, the requirement that the facility be needed and will not duplicate existing services is probably the most germane to DR development. Where, for example, a DR provider proposes to develop a resource or install a facility in an area in which another provider offers a similar service, there could be an objection that the service is not needed, or that it duplicates service already being provided. The report presents examples of cases that have raised and resolved such objections in similar contexts. It also notes that newer regulatory schemes may include other standards for granting CPCNs. Some of these could provide a competitive advantage for cost-effective DR projects, such as those requiring a finding that the proposed addition it is the 'best and most economical technology choice' for the service area, or that cost-effective conservation or alternative energy sources cannot meet the need.

Similar in concept to CPCN statutes are laws that provide for certified retail service territories. These typically are designed to promote the orderly development of retail electric service, avoid wasteful duplication of facilities, and minimize disputes among retail electric suppliers. To these ends, they authorize the division of a state into geographical areas within which each retail electric supplier is certified to supply service. They generally prohibit other retail suppliers from serving those areas, except by agreement or joint petition among the certificated utilities. Beyond these common characteristics, the statutes differ in specifics. The report reviews various examples to suggest the kinds of issues they present for DR.

The report concludes that state certification laws have the potential to impact DR development options, but that they vary considerably in their nature and application. Like the public utility definitions and exemptions discussed above, they must be analyzed case-by-case to gauge their impact on particular DR initiatives. Where they apply, they can either support DR development (where, for example, they establish alternative energy preferences), or hinder it (as where they 
require a strict showing of need and inadequacy of existing services). They can also have a less direct, but no less important, impact on DR projects by providing a forum for competitive challenges and delay: even where DR projects ultimately can meet certification criteria, the time and cost of establishing that through administrative or judicial proceedings could discourage small projects whose value in some cases depends on timely deployment to capture T\&D or other deferral benefits. Accordingly, this is another area where proactive efforts to streamline legislation or implementation procedures could encourage DR development.

Table 1. Summary of Key Legal \& Regulatory Topics \& Their Importance For Dr

\begin{tabular}{|c|c|c|c|}
\hline TOPIC & DESCRIPTION & RELEVANCE & IMPORTANCE \\
\hline $\begin{array}{c}\text { Antitrust \& } \\
\text { anticompetitive } \\
\text { principles } \\
\text { applied to utility DR } \\
\text { activities }\end{array}$ & $\begin{array}{l}\text { Protection against } \\
\text { monopoly subsidies of } \\
\text { competitive activities to the } \\
\text { detriment of ratepayers \& } \\
\text { competitors, \& against } \\
\text { other market power abuses }\end{array}$ & $\begin{array}{l}\text { Can preclude competitive } \\
\text { DR activities by utilities, or } \\
\text { require partial or complete } \\
\text { separation of monopoly \& } \\
\text { competitive activities at } \\
\text { some potential cost in } \\
\text { efficiency \& innovation }\end{array}$ & $\begin{array}{c}\text { Very high } \\
\text { for both utilities } \\
\text { \& potential DR competitors }\end{array}$ \\
\hline $\begin{array}{l}\text { Unbundling } \\
\text { of costs \& rates } \\
\text { under FERC open } \\
\text { access \& state } \\
\text { restructuring }\end{array}$ & $\begin{array}{l}\text { Separation of utility costs } \\
\text { into generation, } \\
\text { transmission, \& distribution, } \\
\text { \& customer charges based } \\
\text { on actual (area- \& time- } \\
\text { specific) marginal costs }\end{array}$ & $\begin{array}{c}\text { Identifies high cost areas \& } \\
\text { permits larger DR } \\
\text { investments to be cost- } \\
\text { effective in selected areas }\end{array}$ & $\begin{array}{l}\text { Potentially very high } \\
\text { if full cost \& rate unbundling } \\
\text { occurs at the retail level \& } \\
\text { both are differentiated by } \\
\text { area \& time }\end{array}$ \\
\hline $\begin{array}{l}\text { State public utility } \\
\text { definitions \& } \\
\text { exemptions } \\
\text { applied to DR facilities } \\
\text { \& services } \\
\end{array}$ & $\begin{array}{l}\text { Define commodities, } \\
\text { services, and interests } \\
\text { subject to regulation, \& } \\
\text { exempt specified resources } \\
\text { \& service configurations }\end{array}$ & $\begin{array}{l}\text { Determines whether DR } \\
\text { facilities and their owners or } \\
\text { operators will be regulated } \\
\text { as public utilities \& entitled } \\
\text { to public utility protections }\end{array}$ & $\begin{array}{c}\text { High } \\
\text { for both utilities } \\
\text { \& potential DR competitors }\end{array}$ \\
\hline $\begin{array}{c}\text { State certification } \\
\text { laws } \\
\text { applied to DR facilities } \\
\text { \& services }\end{array}$ & $\begin{array}{l}\text { Grant exclusive franchises } \\
\text { for geographic areas } \\
\text { \& prohibit entry by others }\end{array}$ & $\begin{array}{l}\text { Determine whether DR } \\
\text { facilities can be built \&/or } \\
\text { service furnished in } \\
\text { particular geographic area }\end{array}$ & $\begin{array}{c}\text { High } \\
\text { for both utilities } \\
\text { \& potential DR competitors }\end{array}$ \\
\hline $\begin{array}{l}\text { Federal vs. state } \\
\text { jurisdictional } \\
\text { issues }\end{array}$ & $\begin{array}{c}\text { Establish boundaries } \\
\text { between FERC \& State } \\
\text { legislative \& commission } \\
\text { authority over generation, } \\
\text { transmission, } \\
\text { \& local distribution }\end{array}$ & $\begin{array}{l}\text { Determine whether FERC or } \\
\text { state legislatures \& utility } \\
\text { commissions regulate } \\
\text { DR facilities \& their owners } \\
\text { \& operators, } \\
\text { \& what rules apply }\end{array}$ & $\begin{array}{c}\text { Moderate } \\
\text { for both utilities \& potential } \\
\text { DR competitors }\end{array}$ \\
\hline $\begin{array}{l}\text { Performance- } \\
\text { based ratemaking } \\
\text { applied to utility DR } \\
\text { activities }\end{array}$ & $\begin{array}{l}\text { Bases utility rates on } \\
\text { performance relative to pre- } \\
\text { established targets, instead } \\
\text { of on utility cost of service }\end{array}$ & $\begin{array}{l}\text { Establishes incentive } \\
\text { structures that reward } \\
\text { efficiency, productivity \& } \\
\text { cost reduction instead of } \\
\text { capital investment per se }\end{array}$ & $\begin{array}{c}\text { Uncertain } \\
\text { because not yet adopted by } \\
\text { many regulators \& depends } \\
\text { on specific incentives } \\
\text { adopted }\end{array}$ \\
\hline $\begin{array}{l}\text { State siting laws } \\
\text { applied to DR facilities } \\
\text { \& services }\end{array}$ & $\begin{array}{l}\text { Require advance approval } \\
\text { to build energy facilities; }\end{array}$ & $\begin{array}{l}\text { Determine whether DR } \\
\text { facilities can be built }\end{array}$ & $\begin{array}{l}\text { Low } \\
\text { because DR are usually } \\
\text { below size threshold }\end{array}$ \\
\hline
\end{tabular}





\section{INTRODUCTION}

\subsection{BACKGROUND}

This report describes legal, regulatory, and institutional considerations likely to shape the development and deployment of distributed resources. It is based on research co-sponsored by the National Renewable Energy Laboratory (NREL) and four investor-owned utilities (Central \& South West Services, Cinergy Corp., Florida Power Corporation, and San Diego Gas \& Electric Company). The research was performed between August 1995 and March 1996 by a team of four consulting firms experienced in energy and utility law, regulation, and economics. It is the survey phase of a project known as the Distributed Resources Institutional Analysis Project, described further below.

For several years, leading electric, gas and combination utilities in the US and Canada have been evaluating the use of distributed resources ("DR") as a way to reduce utility costs, make better use of utility plant, deliver energy to customers more efficiently, and achieve environmental benefits. Most recently, companies interested in DR have shifted their focus to its potential strategic uses in the competitive environment that promises to supplant traditional energy markets in the US and abroad.

The DR concept envisions that traditional utility central station generation, transmission, and distribution will increasingly be supplemented with small, decentralized or "distributed" generation, storage, and demand-side management technologies. These include gas and diesel generators, wind turbines, photovoltaics and other renewables, fuel cells, batteries, and load management devices. Depending on the technology and the need, distributed facilities might be installed on customer premises, or at substations or other locations on the utility's distribution system. In any case they will be strategically sited and operated to add value to the utility system beyond traditional energy and capacity. The added values that make $\mathrm{DR}$ attractive can include some combination of reduced investment risk; deferred transmission and distribution (T\&D) investment; reduced T\&D losses; increased system reliability; customer retention; local environmental benefits; overall system efficiencies; and site-specific economies such as thermal use from cogeneration.

Utility case studies, as well as the work of the Distributed Utility Valuation (DUV) Project cosponsored by NREL and others, have shown that DR can offer substantial, quantifiable benefits where distributed technologies are carefully selected and placed to match special site characteristics and local T\&D needs. Most of those studies have addressed DR economics, evaluation, and planning. They have focused on how to locate valuable sites; whether distributed technologies can yield the benefits hypothesized; how these benefits can be quantified and their value established relative to other utility investments; and how planning and modeling tools can facilitate DR decisions.

The work reported here adds another dimension to these inquiries. It represents a first systematic look at legal, regulatory, and institutional factors that will influence whether DR benefits can be realized in practice; whether they will flow to utilities and their customers or to others; and how utilities can structure their participation to take advantage of DR business opportunities in a changing regulatory environment. Stated differently, this research begins to explore how legal and regulatory considerations might impact stakeholder interest in deploying $D R$, and the avenues available to do that under traditional and emerging regulatory schemes.

Legal and regulatory considerations are singularly important for DR for at least two reasons. The first is that the DR concept departs radically from the central station natural monopoly paradigm on which traditional utility regulation is based. DR benefits do not depend on economies of scale or scope that historically have justified the franchised monopoly and the regulatory system built around it. Instead, they depend on what might be called economies of dispersion, integration, standardization, and mass production. These economies are available through the use of small modular systems placed close to the loads they serve, selectively matched to site conditions, and 
easily transported, installed, and operated. These fundamental differences from central station resources alone suggest that DR will not fit easily within a legal and regulatory system built on natural monopoly concepts, and that widespread DR implementation would have potentially far-reaching legal and institutional implications for the energy and utility industry.

The second reason that legal and regulatory considerations bear importantly on DR planning is that interest in DR has emerged at a time when federal and state utility law is rapidly shifting from traditional monopoly concepts toward a fully competitive environment for electricity supply. Nonutility power producers and energy service companies serve increasing percentages of markets once served exclusively by regulated utilities. Federal law now mandates wholesale wheeling. Federal regulators have ordered open access and unbundling of traditional electric utility functions to advance that mandate. By early 1996, state legislators and regulators in more than 45 states were addressing retail wheeling, restructuring, competition, and/or alternative forms of regulation for electric utilities. Some states have proposed to go beyond the functional unbundling required by federal regulators, to require structural separation (through distinct business entities) of generation, transmission, and distribution functions. These trends continue to accelerate, so utilities and their competitive progeny will need to understand their legal, regulatory, and strategic implications for any DR activities they might be considering.

\subsection{PROJECT OBJECTIVES, STRUCTURE, AND SCOPE}

The Distributed Resources Institutional Analysis Project (Project) has two related and complementary objectives. The first is to identify and describe key elements of the legal and institutional framework for 'DR development. This framework includes barriers, incentives, constraints, and opportunities established by federal and state laws, regulations and agency practices, as well as relations among key stakeholders interested in DR development.

The Project's second objective is to begin to assess the implications of these legal and institutional factors for the development of utility business strategies that can capture potential DR benefits as competition supplants traditional regulation.

The Project originally was conceived in two phases corresponding to these two objectives. This report is the product of the first phase, and is intended to describe important legal and regulatory issues likely to impact DR planning by utilities and others. As originally conceived, a second phase would explore the range of roles available to utilities to implement $D R$, and the implications of the findings reported here for pursuing them under various emerging regulatory scenarios. ${ }^{1}$ Sponsoring utilities and others will need to reexamine their interest in pursuing such work in the light of industry changes occurring since the Project began, so no decisions have yet been made to proceed with this second research phase.

The scope of the research reported here evolved considerably since it was first conceived early in 1993. At that time, the research agenda was expected to focus on the potential impacts of the Public Utility Regulatory Policies Act of 1978 (PURPA), the Public Utility Holding Company Act of 1 '935 (PUHCA), the then-new Energy Policy Act of 1992 (EPACT), conventional antitrust issues, and traditional state law and regulatory policies.

By the time the Project actually got under way in July 1995, repeal or wholesale revision of PURPA and PUHCA appeared imminent. EPACT had caused the Federal Energy Regulatory Commission (FERC) to propose rules that would make transmission fully competitive, and a number

\footnotetext{
${ }^{1}$ Utility roles might range from developing, owning and controlling individual resources, to acting simply as information provider, resource aggregator, system integrator, and/or common carrier. Examples of implementation scenarios might include $\mathrm{DR}$ activities by a vertically integrated utility under traditional cost-based regulation; DR activities by functional units of a utility under various proposed wheeling regimes; or DR activities by a distribution-only entity under some form of incentive regulation.
} 
of states were well on their way to radically restructuring their electric industries. These developments continue in full swing as this report is written. None will be complete for at least several years, and possibly much longer than that. The FERC's new rules will affect all utilities and non-utility suppliers that own or use the interstate grid system. State proceedings will affect utilities and their competitors doing business in those states, and very likely beyond them. In the meantime, traditional state laws and regulatory practices remain in force, and probably will for some time, especially in states that have not (yet) embraced restructuring.

These developments created a moving target for the research reported here. They expanded its scope considerably beyond its original boundaries, and compelled us to look not only at utility law and regulation as we knew it, but at an uncertain future just now taking shape - to keep one eye on the past while hurtling toward the future.

This report reflects these two perspectives. Later sections address traditional utility law and regulation, which will continue to govern the electric industry until it is changed. But critical parts of it are changing, and the report begins by looking at those since they are foremost in many readers' minds, and may fundamentally affect the value of DR to both utilities and energy customers. Whether describing traditional or emerging schemes, the report's primary objective is to begin to define key legal, regulatory, and institutional issues for DR - not to resolve them at this stage, but to suggest what they are and which ones seem especially important.

Very little of the doctrine discussed in the following pages was developed with DR in mind, and even less has been applied to actual DR situations. Accordingly, much of what follows is informed speculation about how principles developed in other contexts might bear on various kinds of DR development, if that development takes some of the shapes its proponents expect.

\subsection{REPORT ORGANIZATION}

Chapter 2 offers a brief overview of the legal and regulatory framework that governs US energy and utility activities. It is intended primarily for DR planners and decisionmakers who are not regularly exposed to legal and regulatory matters, and may not be familiar with the overall structure of legislation, regulations, and court decisions that apply to energy and utility activities. Its purpose is to provide context for specific topics discussed in other portions of the report, and to indicate relationships among the various bodies of federal and state law and regulation affecting DR decisions.

For many utilities considering $\mathrm{DR}$, the threshold questions remain whether DR makes economic sense, and under what conditions DR activities can provide value for customers and competitive advantages for the utility. In the end these are economic questions, but their answers are strongly influenced by legal and regulatory considerations. Chapter 3 reviews recent regulatory developments bearing directly on them. Specifically, it examines potential impacts on the value of DR of wholesale open access proposed in the FERC's March 29, 1995 MegaNOPR $^{2}$, and of recent state commission moves toward performance-based ratemaking. Because these regulatory developments primarily affect the value of DR to customers and utilities, Chapter 3 includes some basic economic analyses to illustrate the effects of the regulatory principles discussed.

Chapter 4 assumes that DR can offer economic value to utilities and energy customers. It focuses instead on competitive issues raised by utility participation in DR markets, and how these issues might shape the structure of such participation. Competitive issues arise under both federal and state law governing antitrust and anticompetitive activities. The chapter emphasizes federal antitrust

\footnotetext{
2 Chapter 3 was completed while the FERC's Notice of Proposed Rulemaking on open access (Docket No. RM95-8-000; March 29, 1995) was pending, and before the FERC issued its final Orders No. 888 and 889 on April 24, 1996. The discussion in Chapter 3 therefore refers to the proposed rule by its popular name, the "MegaNOPR". Although we have not reviewed all aspects of the final rule at this writing, we understand that it made few changes from the proposed rule, and we are not aware of any that would affect the discussion below.
} 
principles and their application to regulated utilities, including examples from telecommunications that offer useful parallels for energy utilities interested in DR. State anticompetitive laws and emerging "regulated competition" statutes are also reviewed briefly.

Chapter 5 steps back from recent competitive developments to review traditional state laws that still govern energy and utility activities in most states. The chapter focuses on state law "public utility" definitions and exemptions, and on facility siting and certification issues. Notwithstanding the current preoccupation with utility restructuring, these laws will continue to govern until and unless they are changed. They have important implications for DR implementation, whether through conventional utilities, their affiliates, or unrelated entities, and must be considered in developing strategies for DR participation.

Chapter 6 highlights key findings from earlier chapters, and offers some overall conclusions and a summary of key legal and regulatory topics and their importance for DR. 


\section{OVERVIEW OF LEGAL AND REGULATORY FRAMEWORK GOVERNING U.S. ENERGY \& UTILITIES}

\subsection{INTRODUCTION}

This section outlines the overall legal and regulatory framework that governs US energy and utility activities. Its purpose is to provide context for specific topics discussed elsewhere in this report. Its contents will be familiar to energy and utility attorneys and to those involved in utility regulatory affairs, but perhaps not to other utility personnel and policymakers responsible for DR decisions, for whom it is intended to provide basic background.

Laws and regulations affecting energy and utilities cut across multiple levels of federal, state and local jurisdiction. They include federal statutes and federal administrative agency regulations and decisions, as well as federal and state court decisions interpreting these. They also include state legislation, state agency rules and decisions, and state court decisions interpreting both federal and state statutes and administrative rules. Finally (although not addressed in this report), they include local planning and zoning rules, ordinances, and decisions that affect energy facility siting and utility operations.

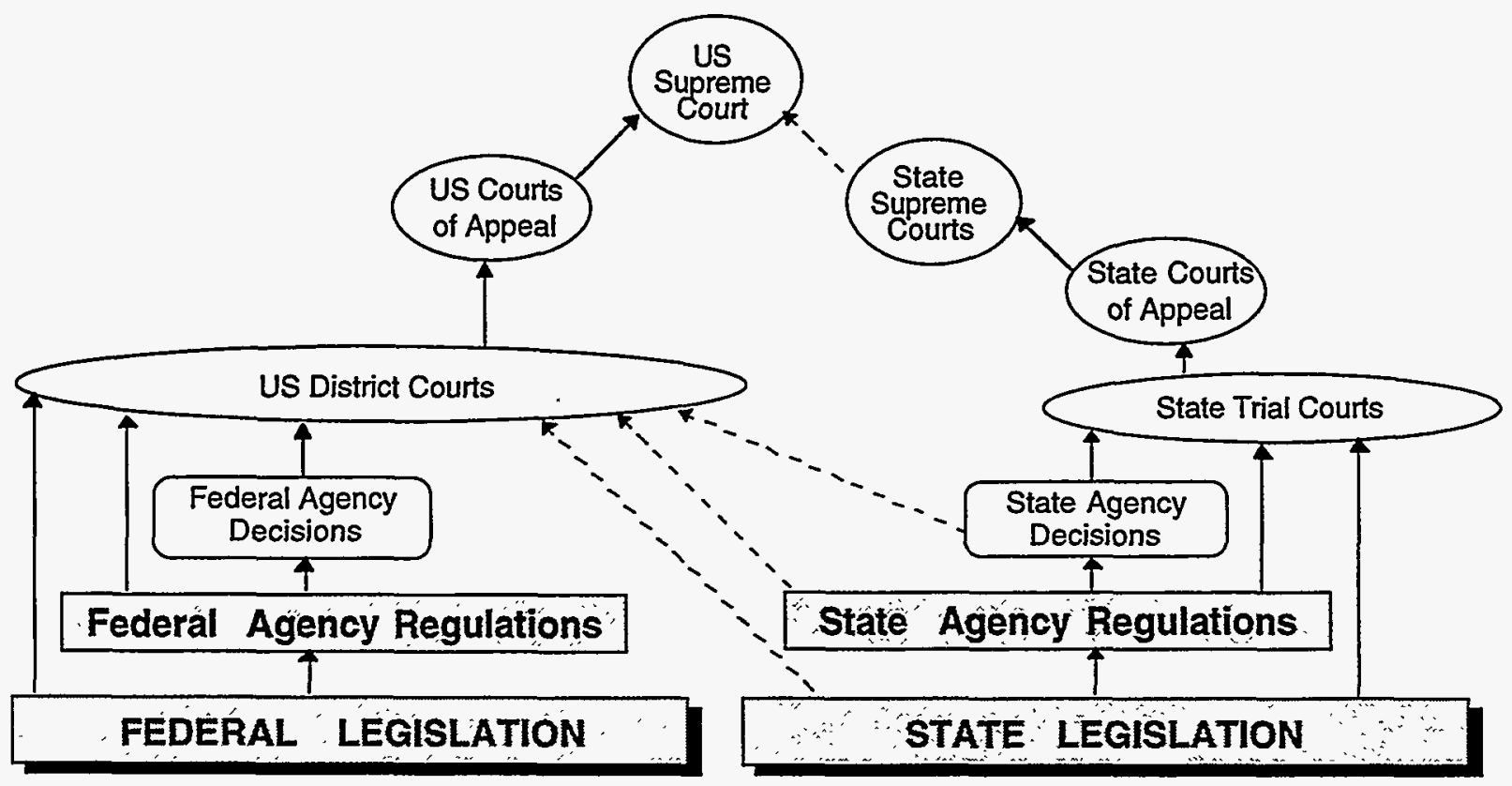

Figure 1. Structure of Laws, Regulations, and Decisions Affecting Energy and Utility Activities

All of these sources of law and regulation can impact the value of DR development, the ownership and siting of DR resources, and/or the operation of DR facilities. The following sections identify important sources of federal and state law potentially affecting these issues, and indicate some of the relationships among them. 


\subsection{FEDERAL LAW, GENERALLY}

Federal legislation and administrative regulations establish and implement national policy as to matters affecting interstate commerce, and they generally have nationwide application. The major pieces of federal energy and utility legislation are the Federal Power Act ("FPA"), ${ }^{1}$ the Public Utility Regulatory Policies Act of 1978 ("PURPA"), ${ }^{2}$ the Energy Policy Act of 1992 ("EPAct"), ${ }^{3}$ and the Public Utility Holding Company Act of 1935 ("PUHCA"). Each of these is implemented in part through regulations and decisions of federal administrative agencies, including the Federal Energy Regulatory Commission ("FERC," as to the FPA, PURPA and EPAct), and the Securities and Exchange Commission ("SEC," as to PUHCA). Among these sources of federal law, EPAct and FPA provisions requiring open transmission access and prohibiting undue discrimination, ${ }^{6}$ and the FERC's new rules implementing them, may have the most far-reaching implications for DR planning and strategy in years to come, for reasons discussed in Chapter 3 below.

Other major bodies of federal law, including environmental laws such as the Clean Air Act and the Clean Water Act and their implementing rules, apply to energy and utilities as they do to other areas of commerce. Federal antitrust laws, including the Sherman Act, Clayton Act, Robinson Patman Act, and Federal Trade Commission Act ${ }^{8}$, also apply to utilities as to other industries. Although their application to regulated industries presents unique and difficult legal issues, they will have increasing impact on utility activities in general and DR activities in particular as electric deregulation proceeds. Indeed, one of the key conclusions of this research is that the antitrust laws will substantially affect whether and how utilities and their affiliates can participate in DR markets. (See Chapter 4)

Federal legislation and administrative actions are subject to review and interpretation by federal courts, and to some extent by state tribunals. Federal courts include US District Courts that act as federal trial courts; regional US Circuit Courts of Appeal that hear appeals from federal District Courts in their circuits; and the US Supreme Court, which presides over appeals from the US Courts of Appeal and, in certain cases, from US District Courts and state courts. (See Figure 1) Among federal court and agency decisions bearing on the possible treatment of utility DR involvement, several lines of antitrust cases are especially instructive. These include Sherman Act cases addressing "state action" antitrust immunity and liability under "monopoly leveraging," "essential facilities" and related doctrines. They also include cases dealing with the AT\&T divestiture and the subsequent restructuring of the Bell Operating Companies. (See Chapter 4)

\subsection{STATE LAW, GENERALLY}

State law and regulation affecting energy and utilities often parallels the federal structure. Almost all states have public utility, public resources, and/or corporation codes that create public

\footnotetext{
116 U.S.C. $\$ \$ 791 \mathrm{a}$ et seq.

2 Pub. L. 95-617, 92 Stat. 3117 (November 9, 1978).

3 Pub. L. 102-486, 106 Stat. 2794 (October 24, 1992).

415 U.S.C. $\$ \$ 79$ et seq. Many PURPA and EPAct provisions amend, and are now part of, the FPA, PUHCA, and other federal legislation. Each of these federal statutes and the agency rules that implement them apply nationwide. However, PURPA and parts of EPAct delegate important responsibilities to state public utility commissions and municipal utilities, resulting in significant differences among the states in putting federal law into practice.

5 Formerly the Federal Power Commission (FPC).

6 See EPAct $\$ \S 721$ and 722 , amending FPA $\$ \$ 211$ and 212 ; 16 U.S.C. $\$ \S 824 d, \mathrm{e}, \mathrm{j}, \mathrm{k}$.

${ }^{7}$ March 29, 1995 Notice of Proposed Rulemaking in Docket Nos. RM95-8-000 and RM95-7-001; commonly referred to as the FERC "MegaNOPR." On April 24, 1996 the FERC issued two final orders in this docket, Order Nos. 888 and 889.

${ }^{8}$ All found at 15 U.S.C. (1992); see specific citations in Chapter 4, infra. 
utility regulatory bodies analogous to the FERC, but responsible for regulating utilities located within the state and activities that affect the state's interests. Among other things, these statutes typically:

- establish regulatory commission authorities and jurisdiction;

- define "public utilities or "public service corporations" subject to regulation; and

- exempt specified entities and activities from state commission jurisdiction.

Under traditional regulatory regimes, these public utility definitions and exemptions can significantly affect the status and treatment of DR facilities. (See Chapter 5, Section 5.1)

A number of states have adopted broad policy statutes that parallel PURPA and/or various other provisions of the Federal Power Act. Many have enacted energy facility siting and/or certification laws that establish criteria and procedures for siting individual utility facilities, or more generally for rendering public utility service. (See Chapter 5, Section 5.2)

Most states have adopted their own statutes paralleling the federal antitrust and unfair competition laws, especially the Sherman Act and the Federal Trade Commission Act. State enactments in these areas are generally similar, but specific language and coverage varies distinctly from state to state, and these variations can make a difference in their significance for DR planning. (See Chapter 4, Section 4.4.7)

Within the framework established by these types of state legislation, state utility and corporation commission activities generally parallel those of the FERC and the SEC. State commissions are primarily responsible for economic regulation of investor-owned utilities to protect the public interest in safe, adequate, reliable supplies of electricity at reasonable prices, and to monitor and preserve the financial health of the utilities that provide such services. These commission responsibilities typically have been discharged for electric utilities through cost-based, rate-of-return regulation. However, various forms of incentive regulation are now emerging as part of the move toward open competition. These can be expected to affect the value of DR to utilities, and their incentives to pursue it. (See Chapter 3, Section 3.2)

State energy and utility legislation and state commission rules and decisions are subject to review and interpretation by state courts and, to the extent they involve federal issues, by federal courts as well. State court organization is similar to that of federal courts, in that legal actions are initiated in state trial courts (analogous to federal District Courts) and are usually appealable through an intermediate court (analogous to US Circuit Courts of Appeal) to a state supreme court. Where state supreme court decisions involve federal issues, they may be reviewable in turn by the federal courts, including the US Supreme Court.

State court decisions can be relevant to DR planning in many areas. Examples include decisions in many states that:

- define the scope of activities that meet statutory "public use" standards and thereby subject energy providers to commission regulatory jurisdiction (see Chapter 5, Section 5.1); and

- decisions interpreting state antitrust, unfair competition, and utility certification statutes (see Chapter 4, Section 4.4.7)

\subsection{FEDERAL VERSUS STATE JURISDICTION}

As the discussion to this point indicates, federal and state interests are parallel and interrelated in many areas of energy and utility regulation. Complex issues of federal/state jurisdiction abound, and demarcations between federal and state jurisdiction are often uncertain. However, the question of whether federal or state regulatory jurisdiction will attach and what rules will apply to particular kinds 
of DR activities can be important, so the following briefly reviews current law and agency interpretations in this area.

Basic Grant of Federal (FERC) Jurisdiction. Part II of the FPA establishes FERC jurisdiction over facilities used for:

1) Transmission of electricity, and/or

2) Wholesale sale of electricity

3) In interstate commerce.9

Scope of Jurisdiction. Where FERC jurisdiction attaches, it includes among other things the authority to review and approve rates for or in connection with transmission and wholesale power sales, and to remedy unreasonable, discriminatory, or preferential rates; ${ }^{10}$ to order physical interconnections and wheeling;" to approve the disposition, merger and consolidation of utility property, and the issuance and acquisition of securities, ${ }^{12}$ and to order service improvements. ${ }^{13}$

Interstate Commerce. Transmission or wholesale sales of electricity must be in "interstate commerce" to trigger FERC jurisdiction. Under the FPA, this requirement is met if electricity is "transmitted from a State and consumed at any point outside thereof". ${ }^{14}$ Even where a utility's facilities are located entirely within a single state and connected to points outside the state only through the bus of another in-state utility, the US Supreme Court has held that power "commingled" with out-of-state power in the bus moves across state lines and constitutes transmission in interstate commerce. ${ }^{15}$ This means in effect that all transmission and wholesale sales are in "interstate commerce" if they employ facilities connected to a multi-state grid - which is true of almost all utility facilities throughout the continental U.S. ${ }^{16}$

Exemptions from FERC Jurisdiction. Except as otherwise specifically provided in the FPA, the Act exempts from FERC jurisdiction facilities used:

1) Only in intrastate commerce, or for

2) Generation, or

3) Local distribution. ${ }^{17}$

Intrastate Commerce. Under the broad definition of interstate commerce just noted, few facilities for transmission or wholesale power sales can be said to be used only in intrastate commerce - i.e., not connected directly or indirectly to the interstate grid. This situation prevails only in

${ }^{9}$ FPA Section 201(b) [16 U.S.C. $\left.\$ 824(b)\right]$ provides in relevant part: "The provisions of this Part shall apply to the transmission of electric energy in interstate commerce and to the sale of electric energy at wholesale in interstate commerce. ...... The Commission shall have jurisdiction over all facilities for such transmission or sale of electric energy, but shall not have jurisdiction ... over facilities used for the generation of electric energy or over facilities used in local distribution or only for the transmission of electric energy in intrastate commerce, or over facilities for the transmission of electric energy consumed wholly by the transmitter."

${ }^{10}$ FPA $\S \S 205,206 ; 16$ U.S.C. $\$ \$ 824$ d,e.

$"$ "FPA $\S \S 202,210-212 ; 16$ U.S.C. $\$ \S 824 a, i, j$.

${ }^{12}$ FPA $\S \S 203,204 ; 16$ U.S.C. $\$ \$ 824 b, c$.

${ }^{13}$ FPA $\$ 207 ; 16$ U.S.C. \$824f.

14 FPA $\$ 201$ (c); 16 U.S.C. $\$ 824(c)$.

15 See, e.g., Federal Power Commission vs. Florida Power \& Light Company, 404 U.S. 453, reh'g denied 405 U.S. 948 (1972); Federal Power Commission vs. Southern California Edison Company, 376 U.S. 205.

${ }^{16}$ Note that although interstate commerce is a necessary condition for federal jurisdiction, it is not a sufficient one: the transaction must still be a "wholesale sale" or "transmission" as distinct from "local distribution," discussed below.

${ }^{17}$ FPA $\$ 201(b)(1) ; 16$ U.S.C. $\$ 824(b)(1)$. The same section exempts facilities used to transmit electricity consumed wholly by the transmitter. 
Hawaii, Alaska, and parts of Texas, so this exemption applies only to a limited subset of US utility facilities.

Generation Facilities. The exemption of generation facilities from FERC jurisdiction is a potentially important one for DR. However, it has received relatively little attention in the literature, and neither the FPA, the case law, nor FERC practice provide unambiguous guidance on the extent and nature of FERC jurisdiction over generation facilities (other than PURPA qualifying facilities, which generally are exempt from the FPA's operative provisions ${ }^{18}$ ).

In particular, there appears to be little authority interpreting the FPA language that exempts generation facilities "except as specifically provided in [Parts II and III of the FPA]". The quoted language might be read to mean that generation facilities are exempt except when used for wholesale power sales subject to FERC jurisdiction under Part II (substantially limiting the scope of the exemption). However, FERC apparently has not read the exception so broadly. It has stated, for example, that the sale of utility generating units supplying bulk power was not a sale of "facilities subject to the jurisdiction of the Commission" that would require FERC approval under FPA §203 (governing dispositions of FERC-jurisdictional facilities), but was a matter of state jurisdiction. ${ }^{20}$

The literature does suggest a distinction between FERC jurisdiction over "facilities" and its jurisdiction over transactions that may involve such facilities. Thus the Commission has indicated that while the FPA generally excludes jurisdiction over generating facilities, FERC does have rate jurisdiction over agreements for the construction of those facilities for utility wholesale customers, because their costs normally have been recovered through wholesale rates. ${ }^{21}$ Similarly, in cases involving utility sales and leasebacks of generating plants, FERC has disclaimed FPA §203 jurisdiction over disposition of the plants based on the "generation facility" exclusion, while noting that its jurisdiction over electricity sales from those plants remains unaffected. ${ }^{22}$ As one commentator has stated more broadly, FERC rate jurisdiction "extends to agreements that govern even one ingredient of the rate public utilities charge their wholesale customers for wholesale electric sales or electric transmission service in interstate commerce, ${ }^{, 23}$ and actions which by themselves are beyond the FPA's reach may be within FERC jurisdiction if they facilitate jurisdictional service. ${ }^{24}$

Informal inquiries of FERC staff suggest that the Commission exercises considerable flexibility in dealing with wholesale power sales from small generating facilities and industrial generators or cogenerators that are not otherwise public utilities under the FPA. While FERC may consider these jurisdictional sales under the FPA, in the few cases that have come before it FERC has generally imposed light-handed regulation, allowing market-based rates or simply deferring to state regulators. ${ }^{25}$

\footnotetext{
${ }^{18}$ PURPA $\S 210($ e); 16 U.S.C. $\$ \S 824 a-3(e)$; 18 C.F.R. $\$ 292.601$. See Chapter 5, Section 5.1.1, infra.

${ }^{19}$ Id; emphasis added.

${ }^{20}$ Entergy Services, Inc., Docket No. ER90-38-000, 51 F.E.R.C. $\mid 61,376$ (1990), especially note 27 and accompanying text, and cases cited there. In the same opinion, however, FERC left open the question of jurisdiction to review the sale's impact on ratepayers of utilities purchasing power from Entergy's system. See also J. Rokach, FERC's Jurisdiction Under Section 205 of the Federal Power Act, 15 Energy Law Journal 83, 113 et seg. (1994).

${ }^{21}$ Rokach, J., supra note 20, at page 106, citing 64 F.E.R.C. I 61,139 (1993), at 61,991. The citation is to the FERC's Jurisdictional Appendix to Prior Notice and Filing Requirements under Part II of the Federal Power Act; Technical Conference and Request for Comments, 57 Fed. Reg. 59,338 (1992).

22 See, e.g., El Paso Electric Co., 36 F.E.R.C. I 61,055 (1986); Pub. Serv. Co. of New Mexico, 33 F.E.R.C. q 61,325 (1995).

${ }^{23}$ Id., at page 98.

${ }^{24}$ Id., at page 109, citing 64 F.E.R.C. I 61,139 (1993), at 61,992.

${ }^{25}$ Personal communication with FERC staff, 1996. Note that in a retail wheeling environment, the FERC would not have authority over retail rates (which are state-jurisdictional), but would have authority over the rates, terms and conditions of the interstate transmission components of the transaction. This means that a retail power contract might be subject to FERC authority with respect to the sale of unbundled transmission services, but under state authority with respect to the sale of generation services.
} 
In any case, state regulatory jurisdiction attaches in almost every state to private ownership or operation of generation facilities which provide retail service "to the public" or "for compensation," unless the facilities are covered by other state law provisions exempting cogeneration, renewables, or other preferred resources or service configurations. (See Chapter 5)

Local Distribution Facilities. The distinction between FERC-jurisdictional transmission and state-jurisdictional "local distribution" is also a difficult one to make, and the cases interpreting it also have not provided clear direction. The US Supreme Court has rejected a lower court's conclusion that FERC jurisdiction reaches any facility used to transmit power from one state to another (which would have gutted the FPA's local distribution exemption). The Court observed that although Congress could constitutionally have conferred such broad jurisdiction over generation, transmission, and distribution facilities if any part of an integrated system crossed a state line, it chose not to do so. Instead, Congress expressly limited Federal Power Commission (now FERC) jurisdiction by excluding facilities used in local distribution - even if some or all of the power they carry originates out-of-state. ${ }^{26}$ In other words, the Court concluded that local distribution facilities are not defined by where their power comes from. Unfortunately, neither the Court nor the Commission in that case explained how they are defined (except to note that they might include substation transformers). ${ }^{27}$

The Supreme Court has since stated that whether facilities are used in local distribution is a factual matter that the Commission must determine based on the facts of each case. In that particular case the Court upheld the FPC's finding that the furnishing of service from $12 \mathrm{kV}$ lines to an industrial customer, a residence, a railroad building, and some lighted highway signs, before the lines reached the substation from which power was sold for resale to consumers, did not make the lines local distribution facilities. ${ }^{28}$

A more recent and perhaps more helpful attempt to distinguish local distribution facilities from jurisdictional facilities appears in the FERC's March 1995 MegaNOPR, where it reviewed its jurisdiction over unbundled wholesale and retail wheeling. ${ }^{29}$ There the FERC concluded from its analysis of the cases that any public utility facilities used to deliver power in interstate commerce from a third-party supplier to $a$ wholesale purchaser are subject to its jurisdiction - regardless of whether they are labeled "transmission," "distribution," or "local distribution." Any facilities used to deliver that power from the wholesaler to the end-user are local distribution facilities subject to state jurisdiction. The only question will be whether the entity receiving the power is a lawful wholesaler. ${ }^{30}$

However, as to facilities used to deliver power in interstate commerce from a third-party supplier directly to an end-user, the FERC concluded that some may be FERC-jurisdictional transmission facilities, and some may be state-jurisdictional local distribution facilities. ${ }^{31}$ In this situation not involving a wholesale sale, the FERC wrote that the cases do not distinguish clearly between jurisdictional transmission and non-jurisdictional local distribution:

While it would be preferable to draw an absolutely "bright" line (e.g., based on technical characteristics such as voltage), this does not appear to be required by case law and, importantly, would not be a workable approach in all cases because of the variety of circumstances that may arise and because utilities themselves classify facilities differently (e.g., one utility may classify a $69 \mathrm{kV}$ facility as transmission; another may classify it as distribution). ${ }^{32}$

\footnotetext{
${ }^{26}$ See Connecticut Light \& Power Company vs. Federal Power Commission, 324 U.S. 515 (1945).

27 Id. at 534.

${ }^{28}$ Federal Power Commission vs. Southern California Edison Company, 376 U.S. 205 (1964).

${ }^{29}$ See note 7, supra, at pp. 249-286.

${ }^{30}$ Id., at 251, 284-286. Cf. Wisconsin-Michigan Power Co. vs. FPC, 197 F.2d 472 (7th Cir. 1952), cert. den., 345 U.S. 934 (1953).

31 Id., at pp. 251-252.

32 Id., at pp. 284-285.
} 
For this reason, the FERC announced that for unbundled retail wheeling it will apply a combined "functional-technical" test, under which it expects that most, if not all, retail wheeling will involve local distribution facilities. Specifically, the FERC will use the following "indicators" to evaluate whether particular facilities of vertically integrated transmission and distribution utilities are FERC-jurisdictional "transmission" or state-jurisdictional "local distribution":

1. Local distribution facilities are normally in close proximity to retail customers.

2. Local distribution facilities are primarily radial in character.

3. Power flows into local distribution systems; it rarely, if ever, flows out.

4. When power enters a local distribution system, it is not reconsigned or transported to some other market.

5. Power entering a local distribution system is consumed in a comparatively restricted geographic area.

6. Meters are based at the transmission/local distribution interface to measure flows into the local distribution system.

7. Local distribution systems will be of reduced voltage..$^{33}$

The following chart illustrates the jurisdictional division for unbundled services that FERC outlined in its open access proceedings.

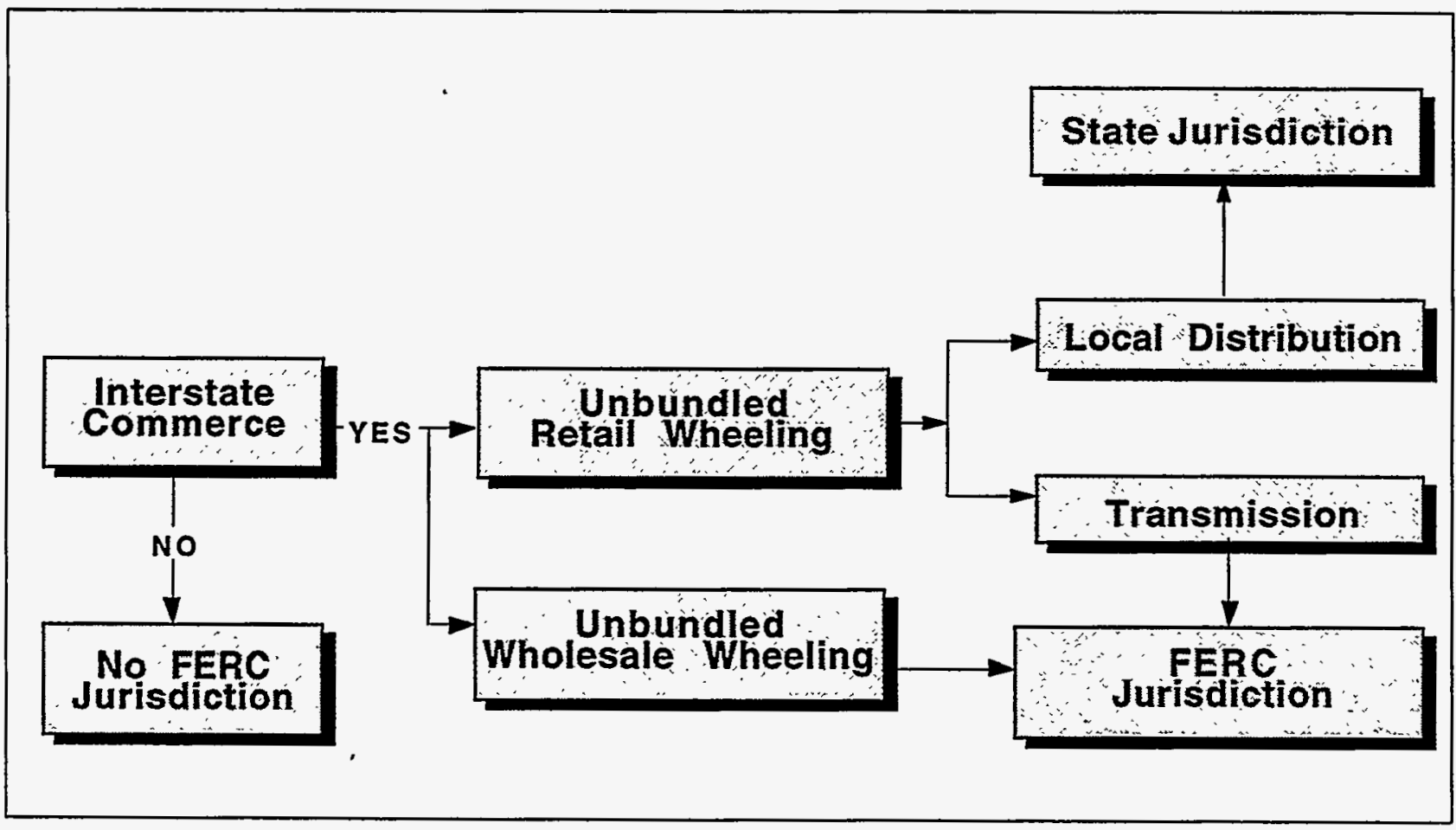

Figure 2. Federal vs. State Jurisdiction Over Unbundled Services

As even this brief review suggests, federal/state jurisdictional questions are complex, and the Congress and the courts ultimately will resolve many of the issues raised in the FERC MegaNOPR and state restructuring proceedings. However, a few points emerge as touchstones in the DR context. One is that, to the extent that DR involve generation facilities, and probably storage or demand-side management as well, they will be subject primarily to state regulatory jurisdiction. To the extent that they make use of "wires" facilities for wholesale sales (whether those facilities are called

33 Id., at p. 285. 
"transmission," "distribution," or "local distribution"), they will be subject to FERC jurisdiction (although FERC may well defer to state regulators as to small facilities or those owned by entities that are not otherwise public utilities). To the extent that DR installations make use of "wires" facilities for "local distribution" directly to end-users, and those facilities match the "indicator" criteria set forth by the FERC, they will be subject to state jurisdiction.

\subsection{CONCLUSIONS REGARDING FEDERAL \& STATE LAW FRAMEWORK}

Federal and state legislators, agencies, and courts all have and exercise responsibilities for energy and utility matters. Jurisdiction is multi-tiered, and its boundaries are often subject to debate at both federal and state levels. In general, however, federal regulators oversee wholesale power sales and transmission by public utilities in interstate commerce (broadly defined) and the facilities used for those purposes, while state regulators supervise retail energy sales and local distribution of energy commodities and services to the public. Antitrust and anticompetitive principles overlay energy and utility activities at both the federal and the state level, and are certain to become more important as competition supplants regulation in the electric industry, and as DR installations expand to meet needs once served almost exclusively by central station facilities.

Where federal legislation and FERC open access initiatives encouraging competition now seem likely to have their greatest impact on DR is not through direct FERC jurisdiction over individual DR facilities, but in the economic and business climate created by utility unbundling and wholesale wheeling. The next section will outline the fundamental changes proposed by FERC in its open access proceedings, and will suggest how they might affect the value of DR to utilities and others interested in its development. 


\section{REGULATORY DEVELOPMENTS AFFECTING THE VALUE OF DISTRIBUTED RESOURCES}

As noted earlier, threshold questions for many considering $D R$ are whether it makes economic sense, and whether it can provide value for energy customers and competitive advantages for energy suppliers. Although these are ultimately economic questions, their answers are strongly influenced by law and regulation. This chapter examines recent legal and regulatory developments likely to affect the value of DR to energy customers and suppliers, and thus their interest in pursuing it.

The following sections focus on the potential impacts of (1) new FERC requirements for nondiscriminatory open-access transmission to be achieved by separating (or "unbundling") the costs of generation, transmission and distribution, and (2) recent initiatives by some state utility commissions to replace traditional cost-based ratemaking with performance-based (or "incentive") ratemaking ("PBR"). These developments are in progress and far from complete at this writing, so some of what follows is necessarily more speculative than later chapters that examine well established areas of law. Still, it is offered here to illustrate how legal and regulatory factors can affect basic DR economics, and to provide some economic context for those chapters. The discussion will suggest that unbundling creates valuable opportunities for DR to compete with each unbundled utility function, and that different forms of unbundling are likely to induce different levels of DR applications. It will also suggest that PBR potentially offers utilities more powerful incentives for DR than traditional cost-of-service regulation, but its actual impact on DR will depend greatly on how individual commissions and utilities choose to implement it.

\subsection{TRANSMISSION OPEN ACCESS \& UNBUNDLING OF SERVICES}

\subsubsection{Background}

The attractiveness and eventual market penetration of DR depends largely on the costs of DR relative to alternatives such as central station generation or grid expansion. In this comparison, the cost of such alternatives typically means the incremental costs of utility options that could be avoided by replacing them with DR. Although most utilities today use system-average costs in this calculation, recent advances in determining avoided costs on an area- and time-specific basis have important implications for DR.'

Whereas system-level utility costs are most sensitive to generation and bulk transmission costs, area- and time-specific costs depend most on distribution and local transmission costs. For utilities with relatively slow total load growth, the latter costs can represent a large share of current investment needs. If utilities know their area- and time-specific costs, they will know where and when their costs are significantly higher than the system average.

Higher costs mean higher avoided costs against which to measure DR options, allowing more expensive measures and larger investments to be cost-effective. These avoided costs have been shown to vary extensively by both time and area, within utilities and between different utilities. ${ }^{2}$

\footnotetext{
${ }^{1}$ See Orans, R., "Area Specific Marginal Costing for Electric Utilities: A Case Study of Transmission and Distribution Costs," PhD Dissertation Submitted to the Department of Civil Engineering of Stanford University, September, 1989.

${ }^{2}$ See Schweppe, F.C., R. Bohn, M.C. Caramenis, "Optimal Pricing in Electrical Network Over Space and Time," Rand Journal of Economics, Vol. 15, \#3, 1984; Woo, C. K., B. Horii, D. Lloyd-Zannetti, and G. Heffner, "Variations in Areaand Time-Specific Marginal Capacity Costs of Electricity Distribution," DA/DSM Paris Conference Proceedings, 1994; and Woo, C.K., D. Lloyd-Zannetti, R. Orans, B. Horii and G. Heffner (1995) "Marginal Capacity Costs of Electricity Distribution and Demand for Distributed Generation," Energy Journal, 16:2, 111-130. 
Thus, selective use of DR (i.e., at the correct location and time) can be used to compete with very high utility avoided cost applications.

DR benefits also vary with the type of customers served. Some customers are willing to pay for a level of premium reliability and quality, beyond that generally provided to utility customers, that DR can cost-effectively provide. ${ }^{3}$ Even so, utilities so far have found relatively few cost-effective grid-connected DR applications. ${ }^{4}$

A number of regulatory and institutional factors pose potential economic barriers to DR market penetration. First, traditional cost of service regulation provides very little financial incentive for vertically integrated utilities to lower their costs of transmission and distribution (T\&D) service. Although recent applications of integrated resource planning in some states have reduced utility incentives to expand generation capacity, incentives remain for T\&D investments in most areas.

Second, information on avoided costs that varies by area and time has been available only to a few of the more innovative utilities. Whereas traditional utility costing practice uses system-average marginal capacity and energy costs to determine the avoided cost for a DR measure, this new approach uses area- and time-specific marginal costs (ATSMC) to target DR in areas where the avoided costs are relatively high. Most utilities still calculate only the average costs of their transmission and distribution systems, making it difficult to observe the economic benefits of DR in their systems.

A third barrier to DR market penetration is that vertically integrated utilities and/or their regulators frequently oppose area-specific ratemaking. For reasons of equity and social policy, utilities generally have been prevented from charging different rates to differently situated customers, even though this practice would be economically efficient when the cost to serve them varies. One of the main benefits of the vertically integrated utility in an expanding system has been to subsidize costly expansion into rural areas through rate averaging. Some state utility commissioners have even referred to area-specific ratemaking as "red-lining", akin to other types of prohibited discrimination.

The unbundling of both costs and rates can be expected to result from the development of competitive power markets as proposed in the FERC MegaNOPR and various state restructuring proceedings. This section will demonstrate that vertical de-integration of utility functions (into GenCo, GridCo, PoolCo, RetailCo, and WireCo ${ }^{5}$ ) creates opportunities for DR to compete with each unbundled function. Each new functional entity will then have its own incentive to price its service to reflect its actual incremental costs.

For example, generators (selling through a PoolCo or bilateral trading) and RetailCos will not be subject to price or rate-of-return regulation, and will develop prices that reflect the market value of their products. If the market is competitive, these values will be close to the unbundled costs of those products. The regulated GridCo, motivated by $\mathrm{PBR}$, can maximize its margin through the creation of spot transmission prices that reflect the marginal costs of using its assets. To the extent that the actual costs of resources are being reflected in prices, the economically correct level of DR (i.e., up to the point where DR marginal costs equal ATSMCs) will be encouraged.

\footnotetext{
${ }^{3}$ See Woo, C.K., R.L. Pupp, R. Mango and T. Flaim (1991), "How Much Do Electricity Consumers Want to Pay for Reliability?" Energy Systems and Policy, 15, 145-159.

4 See Pupp, R. L., Distributed Utility Penetration Study, Report No. TR 106265, Electric Power Research Institute, March 1996; Orans, R, B. Horii, D. Lloyd-Zannetti, S. Price and G. Ball, (1996), A Summary of Area-And Time-Specific Costing: The Applications and Benefits of Disaggregated Costs, Report No. TR-106309, Electric Power Research Institute.

5 GenCo: owns and operates generating assets, supplies electricity at wholesale.

GridCo: owns and manages the transmission system; does not dispatch.

PoolCo: dispatches and manages wholesale power trade; dispatch limited by bilateral contracts.

RetailCo: Buys and sells for customers either from PoolCo or direct from GenCo. 
The following discussion will illustrate that different forms of "functional unbundling" ${ }^{6}$ under consideration in various regulatory forums can yield different levels of cost-effective DR applications. Section 3.1.2 below summarizes the intent and unbundling requirements of FERC's recent open access initiatives. Section 3.1.3 describes several potential market structures, their unbundled rate forms, and their implications for DR. Section 3.1.4 then evaluates the economic incentives for DR from the perspective of different participants under different market structures, and illustrates these through the example of an engine generator.

\subsubsection{Overview of FERC Open Access \& Unbundling Initiatives ${ }^{7}$}

On March 29, 1995, FERC issued a Notice of Proposed Rulemaking (NOPR) proposing to amend its electricity transmission regulations. This so-called "MegaNOPR" included proposals to:

- require utilities to file open-access tariffs for interstate electricity transmission

- require utilities to take transmission and ancillary services ${ }^{8}$ under these tariffs

- issue regulations for tariff filings and initial rates under the tariffs

- issue a supplemental NOPR on the recovery of stranded transition costs

The MegaNOPR proposed to require utilities to offer non-discriminatory open-access tariffs for transmission services. The "golden rule" of FERC's proposal was comparability of rates, contract terms and conditions - i.e., utilities must apply to themselves the same tariffed rates, terms, and conditions for transmission and ancillary services that they charge third-party wholesale transmission customers (see Figures 3 and 4).

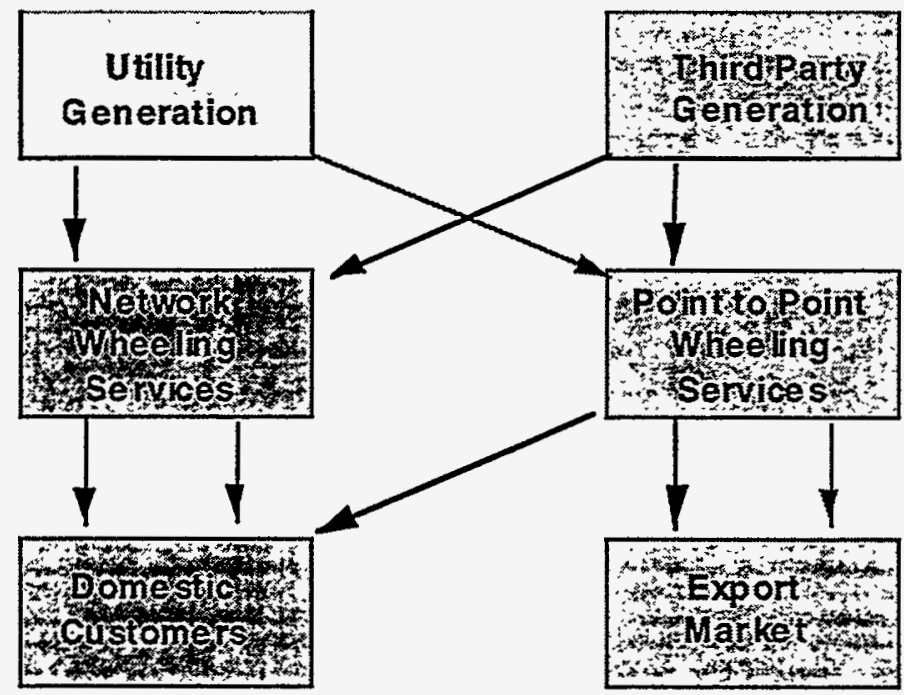

Figure 3. Comparable Use Of Transmission Services By Utilities \& Third-Party Suppliers

\footnotetext{
"As discussed further in the text below, "functional" unbundling refers to separating functions and services such as generation, transmission, and distribution into separate functional units within the same corporate utility entity. This is distinguished from "structural" unbundling, which usually refers to separating utility functions or services by assigning them to legally distinct, and presumably independent, corporate entities.

7 As noted above, this chapter was completed while the FERC's Notice of Proposed Rulemaking on open access (Docket No. RM95-8-000; March 29, 1995) was pending, and before the FERC issued its final Order Nos. 888 and 889 on April 24,1996 . The following discussion therefore refers to the rules proposed in the "MegaNOPR", rather than the final rules adopted in these Orders. Although detailed analysis of the final Orders is beyond the scope of this phase of work, few changes were made from the proposed rules, so references to the MegaNOPR will generally reflect the final rules as well.

${ }^{8}$ Ancillary services include scheduling and dispatch, reactive power and voltage control, spinning and non-spinning reserve, loss compensation, system protection, load following, and energy imbalance services.

${ }^{9}$ These customers include any entity that can obtain transmission service under Section 211 of the Federal Power Act i.e., any electric utility, Federal power marketing agency, or any other person generating electricity for sale for resale.
} 


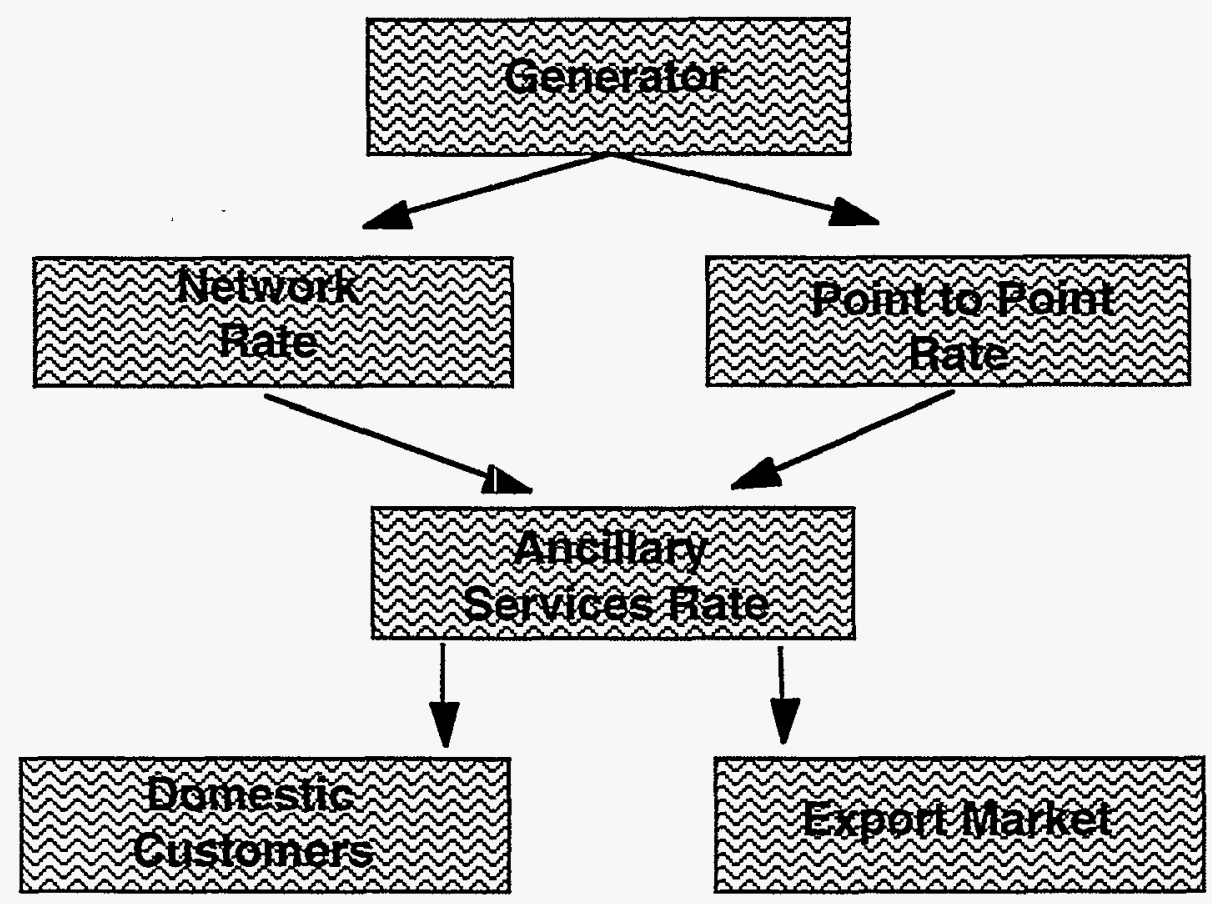

Figure 4. Comparable Use Of Ancillary Services By Utilities And Third-Parties

Implementing these non-discriminatory open-access tariffs essentially requires functional unbundling of wholesale services. This means that (1) customers must receive separately stated rates for transmission and ancillary services, even if they do not yet have access to wholesale service, (2) utilities must rely on the same electric network as their customers for transmission and ancillary services, and (3) all transmission users will have simultaneous access to service information through electronic bulletin boards.

All transmission owners are to offer both firm and non-firm point-to-point transmission services and firm network transmission services, as well as ancillary services. Under point-to-point service, the utility would provide power to designated points of delivery, on either a firm or non-firm basis. Under network service, the utility would make the entire network available to customers under postage-stamp tariffs, regardless of location of loads. All services require non-discriminatory tariffs.

New customers requesting firm service are entitled to use capacity not committed to other firm services during a given scheduling interval ("available transmission capacity"). In addition, utilities must offer to expand transmission capacity or ancillary services if necessary, although it is not clear what criteria determine when expansion is necessary or who will pay for it.

Pricing must be consistent with the FERC's October 26, 1994 Transmission Pricing Policy Statement. If the MegaNOPR's "golden rule" was comparability of rates, then its "silver rule" was conformity of tariffs: rates should be based on transmission revenue requirements and the FERC's "or" rule (allowing utilities to recover the greater of embedded or opportunity cost, but not both).

Stranded costs associated with the development of wholesale markets are to be recovered from departing wholesale customers, and new contracts are to impose exit fees to cover stranded assets. Stranded benefits such as DSM programs, low-income subsidies, and environmental costs are left to the states to recover at the retail distribution level.

The FERC proposed that stranded costs be determined using a "lost revenues" approach, rather than hypothetical cost-of-service calculations, thus avoiding asset-by-asset reviews. Lost revenues are the product of the energy supplied by third-party competitors able to undersell the utility at 
competitive market prices, and the net revenue that would have been received for that displaced energy. These values must be determined by a trade model that can simulate the characteristics and behavior of both the utility and its competitors.

Open-access tariffs were to be implemented in two-stages. In the first, conforming (revenue requirement-based) generic tariffs were to be offered for network, point-to-point, and ancillary services, based on embedded costs. ${ }^{10}$ In the second stage, utilities could file conforming tariffs, but could also file non-conforming tariffs consistent with the Transmission Pricing Policy Statement.

\subsubsection{Potential Market Structures, Unbundled Rate Forms, \& DR Impacts}

The MegaNOPR recognized that common ownership of generation (usually competitive) and transmission (usually natural monopoly) assets can lead to potential problems with self-dealing, cross-subsidization, and discriminatory access to and pricing of network services. MIT economist Paul Joskow has identified three generic market structures that might solve this problem."

The first approach is functional separation of generation, transmission and distribution costs within existing vertically-integrated utilities. As proposed in the MegaNOPR, this "functional unbundling" approach includes open-access pricing rules that provide T\&D access to competing suppliers without regard to ownership. This approach requires regulatory reforms (such as PBR and market-based pricing flexibility) that would remove current incentives to cross-subsidize competitive services from regulated monopoly services, and would prevent uneconomic purchases from the network owners' own generation sources.

The second option contemplates structural separation of generation, transmission and distribution entities through corporate divestiture. The MegaNOPR did not require this. In other countries, such vertical de-integration is usually accompanied by both horizontal de-integration of utility generation portfolios to lessen their market power, and horizontal integration of the transmission network among what have been separate control areas. This structure allows the appropriate dispatching and control of generation assets by a network operator, who is independent and has no financial interest in generation. The operator is also free to fully unbundle the prices paid for network services without regard to the impact on generation.

A third approach is to consolidate network operations into an independent system operator ("ISO", or grid operator, "IGO"). Although not required by the MegaNOPR, this structure was adopted in the California Public Utilities Commission's December 1995 restructuring decision, and is under consideration elsewhere. The ISO is responsible for operating the network, purchasing network support services, and settling imbalances. It is also responsible for creating information necessary to operate a finaricial market that will hedge price risks and trade available transmission capacity. This structure is fully compatible with open access and competition at the retail level.

The FERC has no authority to order retail competition (which falls under state jurisdiction). However, it does have authority over the rates, terms and conditions of the interstate transmission components of retail wheeling. This means that a retail power contract might be subject to state authority with respect to the sale of generation services, but under $F E R C$ authority with respect to the sale of unbundled transmission services. As noted earlier, FERC left the recovery of non-energy related costs (such as stranded transition costs and social costs) to occur at the retail level.

\footnotetext{
${ }^{10}$ Point-to-point tariffs are derived from the annual transmission revenue requirements, divided by the system capacity or the peak demand, multiplied by the fixed-charge rate. Network tariffs are derived from the annual transmission revenue requirements, scaled according to the customer's monthly average share of the peak demand, multiplied by the fixedcharge rate. Certain ancillary services may also include additional costs.

"P. Joskow, "Restructuring to Promote Competition in Electricity: In General and Regarding the PoolCo vs. Bilateral Contracts Debate," Presented at the American Economic Association Meetings, San Francisco, CA, January 6, 1996.
} 
Three unbundled market structures and their resulting rates are analyzed below. The three unbundling scenarios used for this analysis are:

1. Functional unbundling - A wholesale market for generation and postage-stamp tariffs for transmission and distribution service.

Generation rates - Hourly spot price available to all wholesale customers

Transmission rates - Comparable postage-stamp long-term reservation prices

Distribution rates - Bundled with other embedded wholesale customer costs

Rates from wholesale (utility) customers to their retail customers remain bundled postage stamp rates that reflect embedded costs of service.

2. Structural unbundling of transmission - A wholesale system operator with unbundled area-specific transmission prices.

Generation rates - Hourly spot price available to all wholesale customers

Transmission rates - Operator develops spot price \& secondary capacity market

Distribution rates - Bundled with other embedded wholesale-customer costs

Bundled rates to retail customers continue to reflect embedded costs of service.

3. Full unbundling of transmission and distribution rates - Wholesale ISO (PoolCo) and RetailCo's with area-specific marginal T\&D costs and pricing

Generation - Hourly spot price available to all retail customers

Transmission - ISO develops spot price \& secondary capacity market

Distribution - Direct retail access to spot market or via RetailCo

Rates reflect area-specific costs of generation, transmission, distribution.

The economic incentives perceived at the different levels of electricity sales depend on the structure of wholesale prices, which in turn depend on the structure of the industry itself. The first two scenarios generally require only federal action, while the third also would require state action. The resulting price structures for each of these scenarios are summarized in Table 1 .

In the Functional Unbundling scenario, the situation is much as it is today, only with more open competition at the generation level. Generation costs are bundled into postage-stamp rates that reflect the embedded costs of transmission, distribution and other system services. Incentives for DR investments are limited to those of retail distribution utilities applying local IRP, which incorporates cost-effective DR options in support of local infrastructures. In this case, DR may appear attractive as a means to defer imminent investments in local T\&D capacity expansion. ${ }^{12}$ Otherwise, this scenario provides few niches for DR.

In the Structural Unbundling scenario, the same limited local IRP opportunities exist. In addition, there is the possibility that transmission network users (either generators or wholesale, including utility, customers) would pursue DR investments. Their motivation would be to find the most cost-effective means to relieve potentially high transmission costs due to congestion on the existing network. Such investments would compete with the costs of transmission capacity expansion, particularly from the perspective of generators trying to remove transmission constraints to their own sales.

${ }^{12}$ Orans, R., C.K. Woo, J.N. Swisher, B. Wiersma and B. Horii (1992), Targeting DSM for Transmission and Distribution Benefits: $A$ Case Study of PG\&E's Delta District, Report No. TR-100487, Electric Power Research Institute 
TABLE 1. ELECTRIC SERVICE COSTS FOR THREE MARKET-STRUCTURE SCENARIOS

\begin{tabular}{|c|c|c|c|}
\hline SCENARIO: & $\begin{array}{l}\text { Functional } \\
\text { Unbundling }\end{array}$ & $\begin{array}{c}\text { Structural } \\
\text { Unbundling }\end{array}$ & $\begin{array}{l}\text { Full Rate Unbundling } \\
\text { (ISO with Full Retail Access) }\end{array}$ \\
\hline $\begin{array}{l}\text { Generation- } \\
\text { level prices }\end{array}$ & $\begin{array}{l}\text { Hourly spot price } \\
\text { or } \\
\text { fixed-term contract }\end{array}$ & $\begin{array}{l}\text { Hourly spot price } \\
\text { or } \\
\text { fixed-term contract }\end{array}$ & $\begin{array}{l}\text { Hourly spot price } \\
\text { or } \\
\text { fixed-term contract }\end{array}$ \\
\hline $\begin{array}{l}\text { Wholesale- } \\
\text { level prices }\end{array}$ & 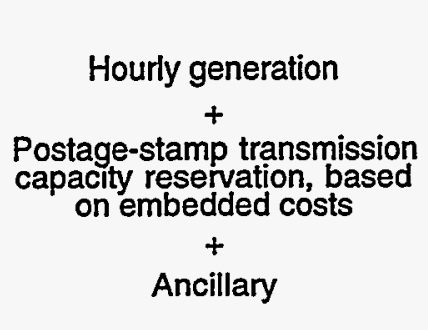 & 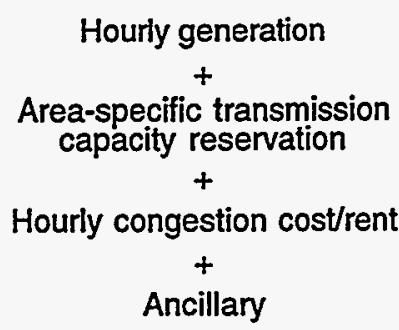 & $\begin{array}{c}\text { Hourly generation } \\
+ \\
\text { Area-specific transmission } \\
\text { capacity reservation } \\
+ \\
\text { Hourly congestion cost/rent } \\
+ \\
\text { Ancillary }\end{array}$ \\
\hline $\begin{array}{l}\text { Retail- } \\
\text { level prices }\end{array}$ & $\begin{array}{c}\text { Average or time-of-use } \\
\text { energy costs } \\
+ \\
\text { Postage-stamp T\&D } \\
+ \\
\text { System costs based on } \\
\text { embedded costs }\end{array}$ & $\begin{array}{c}\text { Average or time-of-use } \\
\text { G\&T costs } \\
+ \\
+ \\
\text { Postage-stamp distribution } \\
+ \\
\text { Other costs based on } \\
\text { embedded costs }\end{array}$ & $\begin{array}{c}\text { Hourly generation } \\
+ \\
\text { Hourly area-specific } \\
\text { transmission costs } \\
+ \\
\begin{array}{c}\text { Hourly area-specific } \\
\text { distribution costs } \\
+ \\
+ \\
\text { System costs }\end{array}\end{array}$ \\
\hline
\end{tabular}

In the Full Unbundling With Retail Access scenario, the local IRP opportunities are replaced by full marginal cost-based price signals at both the wholesale and retail levels. Ideally, this means that generators, wholesale customers, RetailCo's, and even retail customers would perceive an incentive to invest in DR if network constraints drive their T\&D costs upward. Again, DR investments would compete with T\&D capacity up-grades at each level, especially from the generators' perspective.

In this Full Retail Access scenario, customers would have a strong economic incentive to invest in DR options in cases where retail rates reflect high marginal costs of both transmission and distribution. Variations in ATSMC-based rates across different areas motivate area-targeting for DR, and variations in the time when $T \& D$ capacity investments are needed introduce an important time dimension that also affects DR market potential. After expansion investments have been made, the DR potential is exhausted and there is no further scope for cost-effective DR in a given area. By that time, however, other areas may be identified as high avoided-cost opportunities for DR options.

\subsubsection{Example of Economic Incentives for DR Options}

The economic viability of a DR option is measured by its positive net benefits:

Net $D R$ benefit $=D R$ benefit $-D R$ cost

Where:

$D R$ benefit $=$ cost savings - lost revenues - incentives paid, and

cost savings $=$ energy savings + system capacity savings + local T\&D savings.

From the perspective of an IRP analysis, the net benefit is the sum of all benefits and costs for all parties. Total revenue shifts and incentive payments net to zero, so the overall system benefit is: 
System benefit $=$ MEC $\times D k W h / c r f+M C C \times D k W s y s+M D C C \times D k W a r e a-D R c o s t$

Where:

$\mathrm{MEC}=$ marginal energy cost $[\$ / \mathrm{kWh}]$

$\mathrm{MCC}=$ marginal system-level capacity cost $[\$ / \mathrm{kW}]$

$\mathrm{MDCC}=$ marginal distribution capacity cost $[\$ / \mathrm{kW}]$

DkWarea $=$ savings in distribution capacity $[\mathrm{kW}]$

DkWsys $=$ savings in system-level capacity $[\mathrm{kW}]$

$\mathrm{DkWh}=$ savings in annual energy use [kWh/year]

crf = capital recovery factor [1/year]

The prospect of open access and unbundling of utility services, however, can be expected to reduce the application of system-wide IRP. Therefore, it will help to look at the economic incentives and the resulting net benefits as perceived by the different participants in the market structures that may evolve during the next five to ten years.

Assuming for simplicity that the cost of a given DR measure is the same no matter which party invests under which market-structure scenario, then the variation in net benefits depends on the DR benefits gained by a given party under a given scenario. For each of the three scenarios described above, the resulting DR benefits are summarized in Table 2 .

The difference between the cost/rate structures in Table 1 and the benefits shown in Table 2 is that the benefits include only the aspects of each market participant's costs or rates that can be saved by investments in DR. These benefits can range from essentially zero to the full costs or rates, depending on the scenario. This also assumes that the DR option is a supply-side resource that continues to generate revenues. In the case of utility DSM measures, one would also deduct lost customer revenues from the DR benefits.

TABLE 2. DR BENEFITS AS SEEN FROM EACH MARKET PARTICIPANT'S PERSPECTIVE

\begin{tabular}{|c|c|c|c|}
\hline SCENARIO: & $\begin{array}{l}\text { Functional } \\
\text { Unbundling }\end{array}$ & $\begin{array}{l}\text { Structural } \\
\text { Unbundling } \\
\end{array}$ & Full Rate Unbundling $_{\text {(ISO w/Full Retail Access) }}$ \\
\hline Generators & $\begin{array}{c}\text { Generation capacity } \\
\text { \& } \\
\text { energy costs }\end{array}$ & $\begin{array}{c}\text { Generation capacity } \\
\& \text { costs } \\
\text { energy costs } \\
+ \\
\text { Marginal transmission capacity } \\
\text { if a site-dependent constraint } \\
\text { is relieved }\end{array}$ & $\begin{array}{c}\text { Generation capacity } \\
\& \\
\text { energy costs } \\
+ \\
\text { Marginal transmission capacity } \\
\text { if a site-dependent constraint } \\
\text { is relieved }\end{array}$ \\
\hline $\begin{array}{l}\text { Wholesale } \\
\text { Poolco } \\
\text { or } \\
\text { System } \\
\text { Operator }\end{array}$ & $\begin{array}{l}\text { Hourly energy costs - } \\
\text { return on avoided } \\
\text { transmission capacity } \\
\text { (+PBR incentive) }\end{array}$ & $\begin{array}{c}\text { Hourly energy costs } \\
+ \\
\text { Marginal transmission capacity } \\
\text { if a system constraint } \\
\text { is relieved }\end{array}$ & $\begin{array}{c}\text { Hourly energy costs } \\
+ \\
\text { Marginal transmission capacity } \\
\text { if a system constraint } \\
\text { is relieved }\end{array}$ \\
\hline $\begin{array}{l}\text { RetailCo } \\
\text { or } \\
\text { Distribution } \\
\text { Utility }\end{array}$ & $\begin{array}{l}\text { Postage-stamp energy } \\
\text { \& system capacity costs } \\
\text { - return on avoided } \\
\text { distribution capacity } \\
\text { (+PBR/IRP incentive) }\end{array}$ & $\begin{array}{c}\text { Hourly energy costs } \\
+ \\
\text { Area-specific transmission } \\
\text { capacity costs - return on } \\
\text { avoided distribution capacity } \\
\text { (+PBR/IRP incentive) }\end{array}$ & $\begin{array}{c}\text { Hourly spot price } \\
\text { or } \\
\text { Contracted energy } \\
\& / o r \\
\text { Area-specific transm. reservation } \\
+ \\
\text { distribution capacity cost }\end{array}$ \\
\hline Customers & $\begin{array}{l}\text { Postage-stamp rates } \\
\text { based on embedded } \\
\text { system-average costs }\end{array}$ & $\begin{array}{l}\text { Postage-stamp rates } \\
\text { based on embedded } \\
\text { system-average costs. }\end{array}$ & $\begin{array}{l}\text { Unbundled rates } \\
\text { based on ATSMCs } \\
\text { of capacity \& energy }\end{array}$ \\
\hline
\end{tabular}


As an example of DR costs and benefits as seen by each market participant, the following presents a simplified evaluation of a DR device placed optimally in a distribution network with three existing substations and one impending in the distribution expansion plan (see Figure 5). This example illustrates the incentives for DR under the different market-structure scenarios.

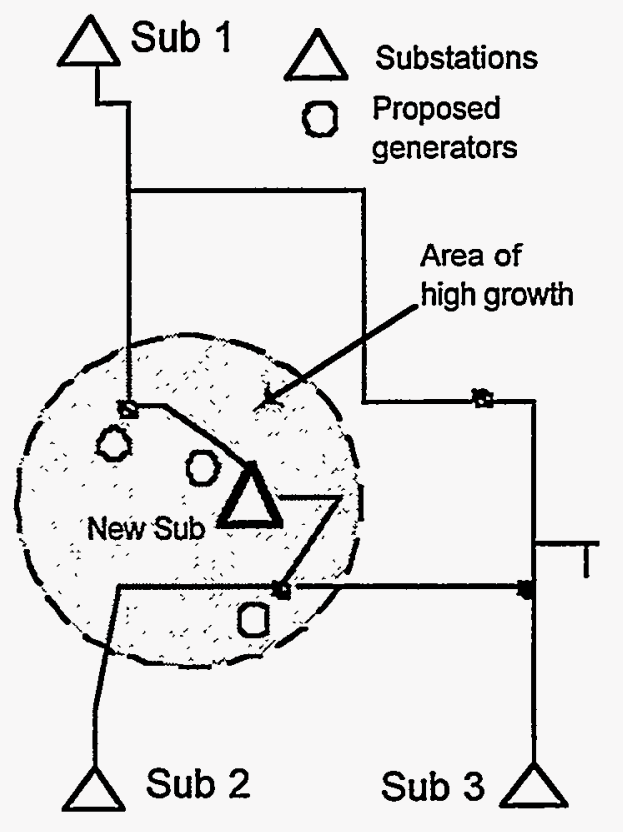

Figure 3. Schematic Layout Of Example Distribution Planning Area

Incentive differences among the three market structures are most evident in the benefits that accrue to the customer and the distribution utility (or RetailCo) from a DR acquisition. For generators and transmission entities (PoolCo or ISO), the benefit of a DR acquisition is mostly the value of its energy production, which must compete with other larger-scale (and probably lower cost) generation options (see Table 2). Generators or PoolCo's could invest in DR to relieve specific transmission constraints to their power sales, but most DR opportunities, like the example presented below, will likely appear at the distribution level.

In this example, the area has an existing load of about $45 \mathrm{MW}$, growing at $2.5 \%$ per year. With no other measures in place, a new substation would be required in year one, at a cost of almost $\$ 4$ million. Assume that the system level costs include energy costs of $\$ 0.02 / \mathrm{kWh}$ and capacity costs of $\$ 50 / \mathrm{kW}$ for generation and $\$ 5 / \mathrm{kW}$ for bulk transmission. The DR options are assumed to include transportable $1 \mathrm{MW}$ engine generators, which can be salvaged immediately if the substation is installed later, and a permanent $3 \mathrm{MW}$ cogeneration unit. Both options have variable costs of $\$ 0.03 / \mathrm{kWh}$ and a capacity cost of $\$ 500 / \mathrm{kW}(\$ 1.5$ million for $3 \mathrm{MW}$ ), so neither is competitive with power from the grid without the benefit of a distribution capacity credit.

Either of the DR options, the 3-MW plant in year one or three 1-MW plants installed over years one through three, can defer the substation by five years, producing a distribution capacity credit of about $\$ 520 / \mathrm{kW}$ (at a real annual discount rate of $7 \%$ ). This value is just enough to justify the 3-MW plant. The three 1-MW plants are more clearly cost effective because of their substantial salvage value in year five when the deferred substation is installed, and because their capital costs are not all incurred in the first year (see Table 3 ). ${ }^{13}$

\footnotetext{
${ }^{13}$ The values in the table are based loosely on an actual case study evaluating for research purposes the economic and engineering impacts of implementing DR. The annual cash flows shown (in present-value terms) reflect the capital costs, equipment $O \& M$, facility operating costs, and salvage.
} 
TABLE 3. PRESENT-VALUE COSTS OF ALTERNATIVE DISTRIBUTION SYSTEM \& DR OPTIONS

\begin{tabular}{|c|c|c|c|}
\hline $\begin{array}{c}\text { PROJECT: } \\
\text { Year }\end{array}$ & $\begin{array}{c}\text { Substation in } \\
\text { Year One } \\
\text { (Dollars) }\end{array}$ & 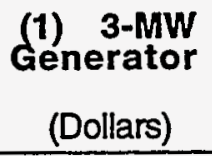 & $\begin{array}{c}\text { (3) 1-MW } \\
\text { Generators } \\
\text { (Dollars) }\end{array}$ \\
\hline 1 & 3,750 & 1,690 & 650 \\
\hline 2 & 100 & 130 & 620 \\
\hline 3 & 100 & 130 & 590 \\
\hline 4 & 100 & 130 & 130 \\
\hline 5 & 90 & 2,900 & 1,775 \\
\hline 6 & 90 & 75 & 75 \\
\hline 7 & 80 & 75 & 75 \\
\hline 8 & 75 & 70 & 70 \\
\hline 9 & 70 & 70 & 70 \\
\hline $\begin{array}{c}10 \\
\text { (salvage) }\end{array}$ & $-1,580$ & $-2,450$ & $-1,700$ \\
\hline $\begin{array}{c}\text { Total Net } \\
\text { Present Value }\end{array}$ & $\$ 2,875$ & $\$ 2,820$ & $\$ 2,355$ \\
\hline
\end{tabular}

Table 3 represents the overall system benefit from alternative distribution system and DR options. However, the market value of the DR options depends on their net benefit to one of the potential investors in the market, rather than their overall system benefit. As suggested above, the likely investors would be the RetailCo or the customers. Table 2 reveals the extent to which each of these parties would perceive the DR options' full benefits, including a distribution capacity credit.

In the first two scenarios, with unbundling and open-access at the wholesale level (Functional and Structural Unbundling), the RetailCo or distribution utility perceives incentives only to the extent that PBR or IRP incentives include the ability to earn a greater return on the DR option than on distribution capacity expansion.

Without such incentives, the energy and system-level capacity savings are insufficient to cover the DR costs (although they are somewhat greater in the second scenario), and the utility loses its traditional return on the planned distribution capacity expansion. In addition, if the DR option were a DSM program rather than a generation device, the utility would also need to be allowed to recover lost revenues to make the program cost effective. The customers, on the other hand, see very little incentive to invest in DR because their benefits still come from rates that are based on embedded system-average costs which are not reduced substantially by DR.

In the Full Retail Access scenario, the RetailCo may see a relatively wide range of energy and system-level capacity costs, depending on the extent to which it has contracted for sufficient and/or excess energy and transmission capacity. If it does not have excess quantities, the hourly spot energy prices and area-specific transmission costs appear as potential DR benefits. In addition, the distribution capacity credit $(\$ 520 / \mathrm{kW})$ is the most important component of the DR benefits. In the example, this benefit alone suffices to make the three 1-MW engines cost-effective as a DR option. The cost-effectiveness of the 3-MW plant is marginal and depends on the system-level capacity and energy credits, and therefore on whether or not these quantities are covered in excess by fixed contracts. 
In this Full Retail Access scenario, customers would see fully unbundled rates based on the ATSMCs of energy, system capacity, and distribution capacity. This means they would see the full distribution capacity credit as a benefit. In the example above, the DR options would appear costeffective. Large customers might be able to make this investment on their own, while smaller customers would have to group together, perhaps in partnership with third-party investors.

With the types of price signals offered by this scenario, the most important remaining barriers to $D R$ investments would likely be institutional. If retail customers perceive the strongest incentives for DR, their ability to form coalitions to pay for cost-effective $D R$ (or, for that matter, grid expansion) becomes a key condition for such investments. It is too early to know whether such investments would be financed by RetailCos, DR suppliers or developers, third-party brokers, or customers themselves, but the best solution may be the one that minimizes institutional barriers.

\subsubsection{Environmental Incentives for DR}

A key feature of many DR technologies is that they are able to rely on renewable resources or are otherwise environmentally benign. Thus, incentives for DR should also tend to favor technologies with low environmental impact. However, environmentalists have expressed strong concern that competitive power markets will be unable to internalize the true costs of emissions, at the expense of renewable technologies. Since many of these are DR technologies, it is relevant to address the relationship between DR incentives and environmental externalities

The costs of environmental emissions from electricity supply are part of the avoided cost of DR. For a given generation-fuel source, emissions are essentially proportional to the amount of electric energy generated. Marginal environmental costs therefore tend to supplement energy costs rather than capacity costs, and including them in avoided cost calculations would tend to favor DR measures with significant energy output, as opposed to strictly capacity-saving options such as storage.

Under a deregulated structure, the utility would have to actually pay environmental costs (rather than use them only for resource planning), in order to have any effect via higher rates. In such a structure, the targeted approach to DR based on high ATSMCs would include avoided emissions as system-level benefits, which add to the area-specific cost savings of DR investments. To the extent that either regulatory or competitive pressures make it difficult to recover $100 \%$ of environmental costs actually incurred, utilities should find energy-producing (or saving) DR increasingly attractive.

In the first two scenarios, regulatory pressure to avoid environmental impacts and externalities could be imposed on the RetailCo or distribution utility via PBR or IRP incentives. This would tend to favor renewable DR options. In the full access scenario, such incentives would have to be exerted via the market in the form of price signals.

To the extent that targeted DR becomes profitable to the utility, then the utility's financial interests will tend to coincide with environmental concerns. Variations in ATSMCs, perhaps combined with reduced emission costs, can make DR cost-effective in high-cost areas, which should appear in additional places over time. As this occurs, renewable-energy and DR advocates will have less need to engage vertically integrated utilities in lengthy IRP proceedings to induce investment in cost-effective resources. 


\subsubsection{Conclusion Regarding Open Access \& Unbundling}

Electric industry restructuring at the FERC has already resulted in functional unbundling at the wholesale level, and ongoing state proceedings are likely to result in various forms of retail access as well. In unbundling scenarios with wholesale open-access, the RetailCo or distribution utility is likely to perceive weak incentives to implement $D R$, which can be overcome only to the extent that $P B R$ or IRP incentives allow a relatively high return on DR options.

In the full retail access scenario, customers would see fully unbundled rates based on the ATSMCs of energy (perhaps including environmental costs), system capacity and distribution capacity. The full distribution capacity credit would be seen as an economic benefit of DR by customers, and the main remaining barriers to DR investments would be institutional.

The preceding discussion suggests that success in creating a competitive bulk power market and implementing light-handed regulation of grid systems may remove important institutional barriers to DR investment, mainly through unbundling of services, costs, and rates. To the extent that area- and time-specific costs are translated to rates, customers themselves will be encouraged to adopt costeffective DR technologies.

\subsection{INCREASED USE OF PERFORMANCE-BASED RATEMAKING}

\subsubsection{Introduction}

As the FERC's open access and unbundling initiatives create new competitive opportunities for $\mathrm{DR}$, performance-based ratemaking ("PBR") has the potential to translate these opportunities into financial gains for utilities that implement DR projects. The following sections contrast traditional cost-of-service ratemaking,, which rewards utilities for prudent capital investment, and emerging performance-based ratemaking, designed to reward utilities for efficiency and productivity gains.

The discussion will suggest that cost-of-service ratemaking in today's high risk environment may appear to favor smaller, less risky DR investments over large central station generation plants. However, $D R$ are often viewed as alternatives to $T \& D$, and traditional regulation provides little incentive to substitute $D R$ for $T \& D$ investment. Emerging performance-based regulatory mechanisms, on the other hand, generally favor DR investments to the extent that DR can minimize costs or promote efficiency. However, not all commissions or utilities will adopt PBR mechanisms, and those that do may combine them with targeted incentives or other measures that can diminish the DR incentives that "pure" PBR could otherwise create.

The following will first describe key characteristics of traditional cost-of-service regulation and some of their implications for DR. It will then describe various forms of broad-based PBR, recent state initiatives to adopt or implement these, and their potential impacts on DR development. Finally, it will discuss more narrowly-targeted incentive mechanisms adopted in some jurisdictions and their effects on DR. This section concludes that the overall impacts of PBR and targeted incentives on DR will depend largely on the specifics of programs adopted by individual jurisdictions.

\subsubsection{Traditional Ratemaking}

Most utilities today operate under traditional "cost of service/rate of return regulation." This type of regulation allows for the recovery of reasonable expenses which are prudently incurred, and for a return on investment that is "used and useful" in providing utility service. The following paragraphs describe these concepts in more detail, then use them to discuss the implications of traditional regulation for $\mathrm{DR}$. 


\section{Cost of Service / Rate of Return Regulation}

Traditional utility regulation starts by selecting a test period in which to evaluate a utility's expenditures in order to establish the amount of revenue that it can collect in rates. This test period may be historical, future or a combination of both. ${ }^{14}$ Jurisdictions using a historical test period set rates based on actual expenditures in that period, often with an adjustment for known future changes. Jurisdictions using a future test period estimate expenditures that will be required to operate the utility in the test period. Expenditures within the test period are classified as either expenses or investment.

Expenses include items such as operation and maintenance, depreciation, interest, and taxes. Expenses judged to be reasonable and prudent are recovered in rates on a dollar-for-dollar basis. Those judged imprudent or unreasonable are disallowed, and therefore not recovered.

Investment is comprised of capital expenditures on plant and equipment used and useful in providing utility service. The total amount of investment approved for recovery by a regulatory commission is known as the ratebase. Most jurisdictions value ratebase at its original cost less depreciation, while a few use "fair value," and fewer still use all available evidence to set the ratebase. ${ }^{15}$

In contrast to the dollar-for-dollar recovery allowed for expenses, utilities are allowed both recovery of, and a return on, their ratebase. Since early in this century, the return authorized on a utility's equity investment generally has been established based on the return available for investments of similar risk. ${ }^{16}$ This return on equity (ROE) is then combined with the utility's cost of senior capital (long-term debt and preferred stock) to establish the utility's weighted average cost of capital also known as its overall rate of return (ROR).

The total amount of expenses and capital investment to be recovered in rates is known as the revenue requirement. The revenue requirement is first allocated among various groups or "classes" of customers (e.g. residential or industrial), and recovered from each class through approved rates.

\section{Implications of Cost of Service/Rate of Return Regulation for DR}

Traditional public utility regulation provides two primary types of incentives to utilities:

1) the incentive to reduce expenses below the level used to set rates, ${ }^{17}$ and

2) the incentive to invest in capital projects.

The incentive to reduce expenses has little direct impact on DR evaluation because DR generally involves capital investments. ${ }^{18}$ However, as discussed below, the incentive to reduce expenses may indirectly cause utilities to substitute capital investment for labor and other expenses. This indirect effect may lead utilities to favor all types of capital expenditures including DR, but offers no insight into the relative preference for DR compared to other capital expenditures.

\footnotetext{
${ }^{14}$ Most jurisdictions use a historical test year. California uses a future test year, while Ohio uses a combined historical and future test year. NARUC, Compilation of Utility Regulatory Policy 1994-1995, p. 422 (1995).

${ }^{15}$ Id. pp. $412-13$

${ }^{16}$ This principle has been articulated and refined by a series of U.S. Supreme Court decisions. The most often cited of these are: Bluefields Water Works \& Improv. Co. v. Public Service Commission of West Virginia, 262 U.S. 679 (1923), and Federal Power Commission v. Hope Natural Gas Co. 320 U.S. 591 (1944).

${ }^{17}$ The incentive to reduce expenses primarily exists because of regulatory lag. If utilities reduce expenses below the level used to set rates, they can increase earnings between rate cases. The longer this period, the stronger the incentive to cut costs.

${ }^{18}$ The impact of DR on operation and maintenance (O\&M) expenses is uncertain. It depends on both the DR technology and the alternative being considered. Where a DR technology is used to replace a transmission or distribution investment O\&M expenses can be expected to rise. As a result, the incentive to control expenses provides no clear-cut encouragement to DR.
} 
The incentive to invest in capital projects would appear to favor larger over smaller capital investments, discouraging rather than encouraging DR. However, events over the past three decades have changed the incentives for capital investment in ways that may actually encourage $D R$.

The apparent incentive to favor capital investments, and especially large capital investments, stems from the relationship between utility returns and the market cost of capital. In theory, the risk-adjusted return on utility investments should be no more attractive than the risk-adjusted returns offered by other investments in the market. In practice, however, utilities historically provided attractive returns measured against the anticipated risks, at least until the late $1960 \mathrm{~s} .{ }^{19}$ For this reason, economists argued that utilities were biased toward capital investment. ${ }^{20}$

A number of events over the last 30 years have changed the incentive to favor investment. First, economies of scale which had characterized the electric utility industry since its inception had largely been exploited by the $1960 \mathrm{~s}^{21}$ Since then, increased investment has become associated not with falling average cost, but with rising average cost and resulting higher rates. During this same period, demand growth declined due to the effects of the oil crises, ${ }^{22}$ leaving many utilities with excess generating capacity. Finally, the risk profile of utility investment shifted, as cost overruns caused regulatory commissions to disallow major capital investments as imprudent.

These events have created a growing reluctance among utilities to invest in large-scale generation plants. Such investments have been increasingly perceived as risky due to their reliance on demand growth projections that have proven overly optimistic; the increased possibility of prudence reviews and associated disallowance; and more recently, the potential for stranded assets as full competition comes closer to reality in the electric industry.

While these factors would tend to favor DR over central station generation because of the smaller size and shorter construction lead times of DR, this comparison may well be inappropriate. Most utilities do not regard DR investments as substitutes for central station generation, but as potential alternatives to transmission and distribution (T\&D) investment.

The risk factors identified above that have made utilities more cautious about investments in generation plant apply with much less force to investments in T\&D. T\&D investments tend to be smaller, less costly, and less subject to regulatory scrutiny. ${ }^{23}$ As a result, there have been few large scale disallowances of T\&D investments.

For these reasons, traditional regulation offers no particular incentives to favor DR investments over $T \& D$ investments. Instead, utility decisions to invest in $D R$ rather than $T \& D$ facilities are driven largely by comparative cost and regulatory requirements (such as facility siting or renewable resource preferences) that may favor one form of investment over the other.

\footnotetext{
${ }^{19}$ L. Hyman, America's Electric Utilities: Past, Present and Future, Chapters 13-14 (1988).

${ }^{20}$ This bias is a central conclusion of the Averch-Johnson theory which holds that when returns are above the cost of capital, regulated firms tend to over invest for a given level of output and to produce less and charge more than unregulated firms. See H. Averch and L. Johnson, "Behavior of the Firm under Regulatory Constraint," American Economic Review (December 1962).

${ }^{21}$ L. Hyman, op.cit. , pp. 102.

${ }^{22}$ Id., pp.105-109.

${ }^{23}$ The exception to this statement is large-scale transmission projects, a number of which have involved substantial cost and consequently received substantial regulatory review. See e.g. 20 CPUC 2d, 115, 195 (establishing a balancing account to permit recovery of a portion of the costs of San Diego Gas \& Electric's [SDG\&E] Southwest Power Link line only if it benefits ratepayers); 39 CPUC 615 (D.91-04-071) (denying certificates of public convenience and necessity to Pacific Gas \& Electric, Southern California Edison, and SDG\&E to participate in the California-Oregon Transmission Project).
} 
From the customer's perspective, traditional regulation affects DR investment decisions mainly through the rate setting process. To the extent that customers can lower their bills through the use of DR, particularly by lowering or avoiding demand charges, DR investments are likely to be attractive.

\subsubsection{Performance-Based Ratemaking}

\section{Introduction}

Much discussion is now taking place about "performance based" or "incentive" ratemaking as part of larger industry discussions on restructuring. ${ }^{24}$ The terms performance based regulation or ratemaking (PBR) include regulatory approaches which use performance relative to a pre-established target to set rates. ${ }^{25}$ These approaches contrast with traditional regulatory models, discussed above, which rely on cost to establish utility rates. Examples of PBR include broad-based performance mechanisms such as price caps and revenue caps (referred to below simply as PBR mechanisms), and targeted incentive mechanisms for everything from demand-side management (DSM), renewable resource, and purchased power savings, to nuclear plant capacity factors.

Few utilities presently operate under broad-based PBR, but a number of jurisdictions are considering expanding its use for some or all of their utilities. In addition, many jurisdictions are implementing or exploring the use of targeted incentives for specific cost items. Despite this increasing interest and investigation, the lack of actual experience with broad-based PBR mechanisms makes it more difficult to predict the practical effects of incentive regulation on DR than to make similar predictions for traditional regulation. Moreover, while traditional regulatory approaches have become somewhat standardized across jurisdictions, approaches to PBR and targeted incentive mechanisms vary widely, and particular regulatory forms adopted depend largely on the regulatory goals and environment of each jurisdiction.

The discussion below begins by describing some of the more prevalent forms of broad-based PBR, followed by some examples of state PBR mechanisms illustrating features that can impact DR. The discussion then examines how various types of PBR can influence the economic incentives that both utilities and their customers have to participate in DR.

The section following that will discuss targeted incentives. It will begin by reviewing some specific targeted incentive mechanisms and how they might impact $D R$, and then examine the relationship between PBR mechanisms and targeted incentives.

\section{PBR Mechanisms}

\section{Price Cap}

Price cap regulation seeks to control a utility's rates by linking future prices to inflation and productivity. In general, a price cap tends to encourage utilities to minimize costs and maximize sales. These tendencies are usually moderated by the inclusion of performance measures and targeted incentives which work to protect attributes such as reliability and activities such as demand-side management.

\footnotetext{
${ }^{24}$ While the current discussion of industry restructuring has focused attention on performance based ratemaking, this regulatory approach predates the restructuring debate. For example, California began adopting performance based ratemaking for San Diego Gas \& Electric in June 1993 (California Public Utilities Commission (CPUC), D.93-06-092), but did not issue its opinion on restructuring until December 1995 (CPUC, D.95-12-063)

${ }^{25}$ See generally, Lawrence J. Hill, A Primer on Incentive Regulation for Electric Utilities Oak Ridge National Laboratory Report ORNL/CON-422 (October 1995). (Hereinafter cited as Primer)
} 
A typical price cap formula is:

$$
P_{1}=P_{0}(1+C P I-X)+Z
$$

Where:

$$
\begin{aligned}
& \mathrm{P}_{1}=\text { price in year one } \\
& \mathrm{P}_{0}=\text { price in the base year } \\
& \mathrm{CPI}=\text { an inflation index } \\
& \mathrm{X}=\text { a productivity factor } \\
& \mathrm{Z}=\text { a factor to account for unanticipated } \\
& \text { and uncontrollable cost increases }
\end{aligned}
$$

The base price is usually set at the prices in effect when the price cap is adopted, but it can be set below or above existing prices to guarantee an immediate rate decrease or increase. The inflation index can be based on an industry-specific price index, or on a broader inflation measure like the consumer price index. In some cases the index is company- rather than industry- specific. ${ }^{26}$ Similarly, the productivity factor can be derived by using either company specific historical productivity data, or some more general statistics on productivity growth. In practice, all of these factors are subject to negotiation in regulatory proceedings. Of course, if the productivity factor is greater than the inflation index, the price cap may decrease below the base year's price, depending on the impact of any $Z$ factors.

$Z$ factors are intended to recognize any unanticipated events beyond the utility's control that will materially impact costs. A frequently cited $Z$ factor example is a change in pollution laws that requires a utility to make unexpected investments in pollution control equipment. Many mechanisms set a threshold level which a $Z$ factor must exceed in order to be considered material. ${ }^{27}$

An important variant of the price cap form of PBR is a rate freeze. Rather than cap rates at inflation minus productivity, a rate freeze sets the cap at or below current the rate level. In effect, this is equivalent to assuming that any cost increases due to inflation are at least equaled by productivity gains. Under a rate freeze, $Z$ factors are rarely allowed.

\section{Revenue Cap}

A revenue cap operates by limiting the growth in a utility's overall revenues, rather than by directly limiting its prices. In general, revenue caps encourage utilities to minimize both costs and sales. Unconstrained, a revenue cap can encourage a utility to maximize its prices. To avoid this, revenue caps in practice often include performance measures, and are calculated on the basis of revenue per customer.

Utilities and regulators often prefer revenue caps to price caps because they need not affect current procedures to allocate the revenue requirement among customer classes or to set final retail

\footnotetext{
${ }^{26}$ SDG\&E uses company specific labor and non-labor indices. The labor index is derived by using a weighted average of administrative, clerical/technical and union wage increases. The non-labor index is a weighted average calculated using the DRI-McGraw Hill forecast of cost escalation by FERC account. See Appendices to Prepared Direct Joint Testimony on SDG\&E's Performance Based Ratemaking Mechanism for Base Rates December 7, 1993 (Application 92-10-017).

${ }^{27}$ SDG\&E's mechanism requires that a $Z$ factor have an impact of at least $\$ 500,000$ before it can be considered. See CPUC, D.94-08-023 (SDG\&E)
} 
prices. In contrast, a price cap may limit the ability to shift costs among or within customer classes, if the cap is applied to individual rather than average rates. ${ }^{28}$

A revenue cap operates in much the same way as a price cap. A base revenue requirement is established, usually based on a utility's current revenue requirement. ${ }^{29}$ This revenue requirement is then indexed for inflation, productivity and customer or sales growth in subsequent years.

Of particular relevance for DR is the treatment of capital additions. Capital additions can either be included in the base revenue requirement, or removed from the base revenue requirement and separately estimated each year. ${ }^{30}$ The use of a forecast creates potential opportunities for DR to improve earnings by beating the forecast; in contrast, a year-by-year estimate would include anticipated $\mathrm{DR}$ and thereby reduce the chance of increased earnings from substituting $\mathrm{DR}$ for more traditional investments.

\section{Revenue Sharing/Rate of Return Bandwidths}

In combination with either a price or a revenue cap, an authorized rate of return target can be established. ${ }^{31}$ Its purpose is to establish anticipated earnings. In most cases, a deadband is instituted around the target rate of return with earnings inside the deadband accruing solely to shareholders, and earnings outside the deadband being shared between ratepayers and shareholders. This sharing may be symmetric or asymmetric. For example, in Consolidated Edison's mechanism, all earnings below the target are shareholders' responsibility. In contrast, shareholders retain only the first 50 basis points of earnings above the target, after which ratepayers receive an increasing share. ${ }^{32}$ An earnings floor or ceiling may also be included. Once the floor or ceiling is reached, either an automatic review or the opportunity for a discretionary review of the PBR mechanism occurs.

Rate of return bandwidths can also be used to directly control earnings independent of any price or revenue cap. Under this approach, a bandwidth is established around an authorized return and rates are only adjusted when earnings fall outside this bandwidth..$^{33}$ Often, a "sharing mechanism" results in rates being adjusted to only partially account for performance outside the bandwidth.

\section{Additional Features: Performance Measures \& Benchmarking}

In addition to price and revenue incentives, many PBR mechanisms include other performance measures not directly tied to cost. Examples are rewards or penalties tied to performance relative to employee safety, reliability, and customer satisfaction. These performance mechanisms are intended to prevent utilities from sacrificing customer service, safety, reliability, or other important attributes in order to achieve lower cost.

PBR mechanisms may also include benchmarking. For example, revenue cap mechanisms may benchmark the participating utility's rates against those of a selected group of utilities. ${ }^{34}$

\footnotetext{
${ }^{28}$ In theory it is possible to cap average rates, allowing some rates to rise and other rates to fall so long as the average remains below the cap. In practice, however, this is rarely done as it greatly reduces the public perception of rate stability that is one of the primary virtues of price caps.

${ }^{29}$ While a revenue cap could, in theory, apply to all revenues. In practice, however, most revenue caps apply to base revenues and exclude fuel and related costs. See CPUC, D.94-08-023 (SDG\&E).

${ }^{30}$ SDG\&E's PBR estimates yearly capital additions using a formula that is distinct from the formula used to estimate expenses. In addition, new major capital facilities are separately included in rates. CPUC, D.94-08-023, pp. 31, 50 (mimeo).

${ }^{31}$ The target can be based on either overall rate of return (ROR) or return on common equity (ROE).

${ }^{32}$ New York Public Service Commission (NYPSC), Opinion 95-3, 161 PUR 4th 51 (April 1995).

${ }^{33}$ Alabama Power has been operating under this type of mechanism since 1982.

${ }^{34}$ Benchmarking may also be used as a replacement for price or revenue caps. Rochester Gas \& Electric has a form of PBR which compares its electric production, transmission and DSM cost performance with that of a selected group of utilities. JNA 


\section{State PBR Activity}

The following paragraphs briefly summarize PBR activities in selected states.

\section{California}

In 1993 the California Public Utilities Commission (CPUC) approved PBR for San Diego Gas \& Electric's activities (Gas Procurement, and Electric Generation and Dispatch) that were previously addressed through the energy cost adjustment clause (ECAC) proceeding, a type of fuel offset. ${ }^{35}$ This PBR mechanism compares actual and forecast performance in these areas for costs judged to be within management's ability to control. To the extent that SDG\&E's costs are lower than the forecast costs, it receives an increasing share of the savings. If its costs exceed the forecast, shareholders bear an increasing portion of the excess. If costs exceed the forecast by more than $6 \%$, a regulatory review is triggered. Costs which the CPUC judges to be outside management's control are trued up monthly and thus do not impact the forecast. ${ }^{36}$

In 1994, the CPUC followed its initial PBR effort for SDG\&E with a comprehensive base rate PBR mechanism. This mechanism caps base revenues using a formula based on inflation, productivity improvement and customer growth. The mechanism contains provisions for sharing any earnings above a threshold between ratepayers and shareholders. ${ }^{37}$ Also included are features which reward or penalize SDG\&E for its performance relative to indicators for employee safety, reliability, customer satisfaction and rates. These performance indicators and the earnings mechanism are linked, Failure to meet any of the performance indicators can reduce or eliminate earnings increases obtained by beating the revenue cap. Conversely, failure to meet the revenue cap limits can wipe out any earnings produced by exceeding the performance indicators.

California's other large investor-owned utilities, Pacific Gas \& Electric (PG\&E) and Southern California Edison (SCE), have both applied for PBR mechanisms. ${ }^{38}$ These applications were not acted upon during the time the Commission initially considered restructuring. The Commission's December 1995 restructuring decision reaffirms its commitment to $\mathrm{PBR}^{39}$ It requires the three major California utilities (PG\&E, SCE and SDG\&E) to propose PBR mechanisms to regulate their generation and distribution activities. PG\&E and SCE were also directed to indicate the continuing viability of their pending applications. ${ }^{40}$ In January 1996, PG\&E indicated that it would re-file its pending PBR application; Edison expressed a desire to have its pending application approved with modifications.

\section{Indiana}

In April 1995 Indiana adopted legislation (discussed in section 4.6.2, below) which permits the Indiana Utility Regulatory Commission (IURC) to adopt alternative forms of regulation for energy

If Rochester's cost decrease more rapidly or increase more slowly than the comparison group, it earns an ROR bonus. August 24, 1993 Order approving settlement.

35 CPUC, D.93-06-092

${ }^{36}$ For an evaluation of SDG\&E's Phase 1 PBR mechanisms, see Vantage Consulting, SDG\&E's Performance-Based Ratemaking Experiment, Final Report (Generation and Dispatch Mechanism; Gas Procurement Mechanism) (February, 1996).

${ }^{37}$ The SDG\&E base rate mechanism sharing provisions work as follow. The first 100 basis points of earnings above the authorized rate of return are allocated to shareholders. The next 50 basis points are allocated $25 \%$ to ratepayers and $75 \%$ to shareholders. Above 150 basis points, earnings are allocated equally between shareholders and ratepayers. All eamings below the authorized rate of return are allocated to shareholders. If earnings are 300 or more basis points above or below the authorized rate of return an automatic review is triggered. See CPUC, D.94-08-023, p.62 (mimeo).

${ }^{38}$ PacifiCorp. which has relatively few California customers (approximately 40,000) operates under a price-cap which is in effect until the end of 1996.

${ }^{39}$ CPUC, D.95-12-063 as modified by D.96-01-009. pp. 83-89 (mimeo) 
utilities. ${ }^{41}$ Under the statute, utilities may request the IURC to decline its traditional regulatory jurisdiction, and may instead elect to be regulated under an alternative regulatory practice, such as price caps or index based prices, by filing an alternative regulatory plan..$^{42}$ As of February 1996, no alternative regulatory plan had been approved for Indiana electric utilities under this legislation.

\section{Massachusetts}

In February 1995 the Massachusetts Department of Public Utilities (DPU) issued an opinion on incentive regulation which identified a number of criteria that it would use for judging incentive regulation proposals. ${ }^{43}$ These criteria require that any incentive regulation increase the incentives inherent in traditional regulation by providing utilities an opportunity to earn greater rewards in exchange for assuming greater risk. The opinion emphasizes the need to focus incentive mechanisms on achieving comprehensive results rather than on cost recovery alone. In particular, incentive mechanisms should not reduce safety, reliability, or customer service and should be designed to achieve measurable results at calculable administrative costs. As of February 1996, no incentive regulation plan had been approved for a Massachusetts electric utility.

\section{New York}

Rather than adopting a standard form of incentive regulation for its electric utilities, the New York Public Service Commission (PSC) has approved a number of different incentive regulation proposals filed by various utilities. These incentive mechanisms are likely to be superseded by utility applications filed in response to the PSC's anticipated restructuring decision.

A PBR mechanism was adopted for Consolidated Edison in April 1995..$^{44}$ It provided for a oneyear freeze in base rates. In subsequent years a formula based on allowed revenue per customer will be used to set base rates with an annual true-up for over or under collections. This formula will be adjusted for specific provisions regarding independent power, property taxes, DSM and renewable resource project expenses. Base rates will also be adjusted to reflect any rewards or penalties for DSM, service quality or reliability. Fuel costs are subject to a pass-through, but the utility is responsible for $30 \%$ of the variation from a pre-established target.

Consolidated Edison's return on equity (ROE) was established at $11.1 \%$ for the first year. It will be adjusted for subsequent years by one-half of any increase or decrease in the interest rate for 30 year Treasury bonds. If earned ROE exceeds the target by more than 50 basis points, the excess will be shared with ratepayers. The first 100 basis points, above the 50 basis point deadband, are shared equally between ratepayers and shareholders. Amounts above 150 basis points go $75 \%$ to ratepayers and $25 \%$ to shareholders. Any shortfall below the targeted ROE accrues solely to shareholders.

New York State Electric and Gas Corporation has a price cap mechanism in place which sets the permissible level of average price increases for three years. ${ }^{45}$ Certain industrial customers are exempted from these increases. The mechanism also contains ROE targets and a sharing mechanism. In addition, pre-existing targeted incentives for service quality and reliability were maintained.

\section{Wisconsin}

As of this writing, Wisconsin had not adopted a comprehensive PBR mechanism. A series of targeted incentives have been approved for Wisconsin Power and Light. These include an elimination

\footnotetext{
${ }^{41}$ Burns Ind. Code Ann. § 8-1-2.5-1 et. seq. (1995)

${ }^{42}$ Burns Ind. Code Ann. § 8-1-2.5-6 (1995)

${ }^{43}$ Incentive Regulation D.P.U. 94-158 (February 24, 1995)

${ }^{44}$ NYPSC, Opinion and Order Approving Settlement, Opinion 95-3, Case 94-E-0334 (April 1995).

${ }^{45}$ NYPSC, Opinion 95-17 (September 1995).
} 
of fuel rules that reconciled forecast and actual fuel costs, a reward / penalty mechanism for performance relative to a target for sulfur dioxide emissions, and a reward/penalty mechanism based on a target for customer outages. ${ }^{46}$ In adopting the emissions target, the Commission specifically stated that this target would reduce any incentive that the company had to use higher sulfur coal in order to save on fuel costs.

\section{Potential Impact of PBR on DR}

\section{PBR Generally}

The essential feature of PBR is that it attempts to tie a utility's earnings to its success in controlling costs. In theory, this feature works to encourage DR where it can be cost-effectively substituted for other potential expenditures such as T\&D investments. In actual practice, however, no utility has implemented a "pure" PBR because all have been combined with performance measures or targeted incentives. As a result, PBR's impact on DR is uncertain: it depends on the combined effect of the type of DR, the specific features contained in an approved PBR mechanism, and the impacts of any targeted incentives or performance measures.

A number of issues will influence the impact of PBR on DR development. First, as discussed above with respect to traditional regulation, it depends on the categorization of particular $D R$ activities by regulatory commissions. Many PBR mechanisms apply different treatment to different types of costs. For example, if a DR project is categorized as R\&D or DSM it may come under targeted incentive mechanisms designed to encourage these activities. For example, the SDG\&E mechanism discussed above completely removes DSM expenditures from its PBR formula and continues pre-existing shareholder incentives for DSM. Another example of treatment based on categorization is found in a proposed mechanism which separates generation costs from T\&D costs. ${ }^{47}$ Thus, for PBR, as for traditional regulation, the categorization of specific DR activities will influence the regulatory treatment that they receive.

Second, PBR's impact on DR depends on the relative importance of the cost control mechanism and other additional features included in the PBR. PBR mechanisms with strong performance measures may impact the attractiveness of DR. For example, both the SDG\&E and Con Ed PBR mechanisms discussed above contain rewards and penalties based on reliability measures. In general, these types of measures will tend to encourage the use of DR to improve reliability. But how these measures (or any of the other performance measures typically associated with PBR mechanisms) will actually impact a specific DR project depends on the overall economics of the DR project, and the strength of the cost control features in the PBR mechanism.

Third, the degree of pricing flexibility permitted by a PBR mechanism may determine whether the utility or its customers have the incentive to implement DR. Price cap regulation by its very nature prevents prices from rising above the cap. This feature often limits a utility's ability to raise rates to some customers in order to lower rates to other customers. As a result, where current rate structures encourage customers to install DR to avoid high peak period demand charges or high rates generally, price caps may make it more difficult for utilities to change their rates in order to respond to this situation. This difficulty can be ameliorated to the extent that utilities possess sufficient downward price flexibility to reduce the customers' incentive to install DR without raising rates to other customers.

The rate impacts of revenue caps on DR are more difficult to predict because revenue caps do not directly affect rates. Instead, where revenue caps are used rates tend to be set in a separate proceeding outside the PBR process. As a result, the amount of pricing flexibility permitted by a

\footnotetext{
${ }^{46}$ Wisconsin Public Service Commission, 6680-UR-109, Wisconsin Power and Light Company, (December 1994).

${ }^{47}$ Southern California Edison, Comments of SCE on Commission Proposed Policy Decision, R.94-04-031/I.94-04-032 (July 1995)
} 
particular revenue cap will depend on the specific results of associated rate setting proceedings. Again, it is the specific treatment of pricing that will affect this aspect of how PBR influences DR development by customers.

Finally, the impact of PBR mechanisms on DR will be influenced by the impacts of other regulation such as resource planning procedures and facility siting, discussed later in this report. These are mentioned here, however, because they may work to either promote or retard the incentives to promote DR inherent in PBR mechanisms. For example, while the cost minimization features of a $\mathrm{PBR}$ mechanism tend to promote $\mathrm{DR}$ as an alternative to $T \& D$ expenditures, they may not be effective if competitive bidding requirements and their associated transactions costs effectively preclude small scale generation. Conversely, to the extent that facility siting requirements impact the cost and viability of transmission projects, they may serve to encourage DR technologies which are either exempt from these requirements or are below their minimum size thresholds.

\section{Price Caps versus Revenue Caps}

The major differences between price and revenue caps are summarized in the following table and explained further in the text below.

TABLE 4. COMPARISON OF PRICE AND REVENUE CAPS

\begin{tabular}{|l|c|}
\hline PRICE CAPS & REVENUE CAPS \\
Minimize costs & Minimize costs \\
Maximize sales & Uncertain impact on sales \\
Cover all prices & Exempt certain revenues \\
\hline
\end{tabular}

While both price and revenue caps encourage utilities to lower costs, each may create different impacts on DR. First, price caps tend to encourage utilities to maximize sales. ${ }^{48}$ This will work to minimize DSM as a DR option, but may also work to increase the use of other DR options as sales growth impacts the T\&D system. The impact of revenue caps on sales depends on the type of growth factor included. ${ }^{49}$ If growth is linked directly to sales, then a revenue cap provides the same type of sales incentive that a price cap provides. However, if the growth factor is linked to customers, utilities have an incentive to reduce cost per customer. This in turn produces an incentive to reduce sales which would tend to encourage DSM.

Second, while price caps apply to all prices, revenue caps rarely apply to all revenues. Thus, a revenue cap may allow more opportunities to encourage specific types of $D R$ where certain types of DR costs are excluded from the cap.

Finally, economic theory suggests that a price cap with flexibility will induce utilities to move toward Ramsey pricing where rates are set in inverse proportion to the elasticity of each customer class. ${ }^{50}$ Under this result, the customer classes that would have the greatest likelihood of installing $\mathrm{DR}$, will receive the least price incentive to do so. In contrast, a theoretical argument has been developed which indicates that revenue caps may cause the greatest price increases to the most elastic customers. ${ }^{\text {sl }}$ This would work to encourage DR by increasing the savings that customers could achieve by installing $\mathrm{DR}$. In practice, however, competitive considerations and regulatory intervention are likely to severely limit the practical consequences of this argument.

\footnotetext{
${ }^{48}$ See G. Comnes, S. Stoft, N. Greene and L. Hill, Performance Based Ratemaking for Electric Utilities: Review of Plans and Analysis of Economic and Resource-Planning Issues, LBL-37577, Vol. I, p.59 (November 1995) (Hereinafter cited as Comnes et. al.).

${ }^{49}$ See Primer, p. 11.

${ }^{50}$ See Primer , p. 32.

${ }^{51}$ See Comnes et. al. , pp. 80-82.
} 
All comprehensive PBR mechanisms adopted or proposed to date have included specific targeted incentives or performance measures. For this reason, general conclusions about the theoretical impacts of price versus revenue caps on DR ultimately are of limited value. In practice, participants concerned about the impacts of a specific PBR proposal on DR must analyze both its structure and the performance measures or targeted incentives that it includes to accurately assess those impacts.

\section{Conclusions on PBR and DR}

While PBR is designed to drive utilities to control costs, as noted above, Commissions have recognized that such behavior may have undesirable effects on service quality, reliability, DSM and other non-price public policies. As a result, additional features have been grafted onto PBR mechanisms to address these concerns. The interaction of these additional features and the incentives found in a PBR mechanism may encourage DR. However, irrespective of any economic incentives to introduce DR provided by a PBR mechanism, other legal and regulatory provisions may limit or even prohibit utility DR activity.

\section{Targeted Incentive Mechanisms}

In addition to the broad-based PBR mechanisms described above, various jurisdictions have adopted a number of targeted incentive mechanisms that can impact DR activity. In this decade, many regulatory commissions have created incentive mechanisms to encourage DSM. They have also adopted mechanisms to encourage renewable energy resources and reduced air emissions. These types of targeted incentives and their potential impact on DR are described below.

\section{DSM Incentives}

A common form of targeted incentive increases a utility's earnings based on its success in implementing DSM. ${ }^{52}$ Three general types of DSM incentives have been approved. "Shared savings" incentives estimate the net benefits of energy and capacity savings created by utility DSM measures and apportion these benefits between ratepayers and utility shareholders. "Return on equity (ROE ) bonus" incentives adjust a utility's authorized rate of return based on its success in implementing DSM. "Cost plus" incentives allow utilities to earn a bonus on DSM expenditures. DSM incentives are usually limited to traditional energy conservation and load management technologies. ${ }^{53}$ As a result, their applicability to DR is limited.

Among many possible examples of DSM incentive programs, California's three major investorowned utilities operate under a complex shared savings mechanism. ${ }^{54}$ It provides for rewards and penalties based on actual performance relative to a forecast of the net benefits created by certain energy efficiency programs. Once actual performance exceeds the established deadband, utilities earn thirty percent of the net benefits created. In contrast, if utilities fall significantly below their forecast they can pay penalties which, in an extreme case, could result in their failing to recover any funds spent on energy efficiency programs. The rewards or penalties are recovered over seven to ten years, depending on the specific program involved.

\footnotetext{
${ }^{52}$ See NARUC, op. Cit. p. 513-14 (1995).

${ }^{53}$ Energy conservation reduces a customer's overall energy use for the same amount of work. Load management reduces peak period energy use without substantially increasing overall energy use. See, California Energy Commission and CPUC, Standard Practice Manual: Economic Analysis of Demand-Side Management Programs, p. 25 (1987)

${ }^{54}$ This mechanism was standardized for the three utilities in 1994. See, CPUC, D.94-10-059.
} 
In calculating the benefits of DSM programs, shared savings mechanisms consider both avoided generation costs and avoided transmission and distribution costs. ${ }^{55}$ In this way, shared savings mechanisms create a specific incentive for DR measures that qualify as energy efficiency programs. The prevalence of DSM incentives may create a preference for DSM over other types of DR which do not receive any incentive treatment.

\section{Other Targeted Incentives}

Other targeted incentive mechanisms reward utilities for lowering their cost of fuel or purchased power, expanding the use of renewable energy or decreasing sulfur dioxide emissions. Given the specificity of these incentive mechanisms it is impossible to generalize their impacts on DR. However, the following examples of specific targeted incentives suggest how they might impact DR.

\section{Renewable Energy Incentives}

The Wisconsin Public Service Commission has instituted a plan to encourage utilities in that state to use renewable resources. ${ }^{56}$ Under this plan, each kilowatt hour generated from a renewable resource, whether owned by a utility or a non-utility generator, earns an incentive of 0.25 or 0.75 cents, depending on the generation technology used. ${ }^{57}$ The amount of the incentive is calculated by multiplying actual metered renewable generation by the applicable incentive rate. The incentive earned is recovered in the following year through a one-year increase in the utility's rate of return.

Incentive mechanisms aimed at encouraging renewable energy procurement could provide an incentive to choose wind or solar DR applications. The effectiveness of this incentive would be determined by its impact relative to any cost differential for the renewable resource. This calculation must be performed for each individual DR project in order to gauge this incentive's impact.

\section{Purchased Power Incentives}

The Texas Legislature has specifically authorized the Texas PUC to use a mark-up or other mechanism to "encourage the utility to include economical purchased power as part of its energy and capacity resource supply plan. ${ }^{158}$ This provision is intended to compensate the utility for any financial risks associated with power purchases and the value the utility adds in making purchased power available to its customers.

Depending on its implementation, this type of mechanism could spur utilities to acquire DR from customers and third party providers. It could allow a utility to both obtain the benefits of DR and increase earnings by working with other parties who would install generation in areas with high $T \& D$ costs. However, competitive bidding requirements and the transactions costs associated with them could effectively preclude this approach by inadequately recognizing area-specific benefits, and by making small-scale generation uneconomic due to the added costs of preparing and submitting bids.

\section{Relationship Between Targeted Incentives and PBR}

The relationship between targeted incentive regulation and PBR is complex. As more jurisdictions move to PBR, pressure will develop to incorporate existing targeted incentives into the overall PBR mechanism in order to reduce the regulatory burden and avoid duplicative or conflicting

\footnotetext{
${ }^{55}$ See, Califormia Energy Commission and CPUC, op. cit., p. 25 (1987). Utility practice varies as to whether local or system-wide avoided T\&D values are used to calculate net benefits. PG\&E uses the local T\&D values produced through its area cost studies, while Southern California Edison uses system-wide values.

${ }^{56}$ Wisconsin Public Service Commission, Docket 05-EP-6 (Advance Plan 6) (1993).

${ }^{57}$ Hydro power and biomass are among the technologies receiving 0.25 cents per $\mathrm{kWh}$, while solar and wind technologies receive 0.75 cents per $\mathrm{kWh}$.

${ }^{58}$ Public Utility Regulatory Act of 1995 (Article 1446c-0) $§ 2.1511$ 
incentives. At the same time, adoption of a broad-based PBR mechanism can itself lead to the adoption of new targeted incentives where PBR discourages actions that regulatory commissions wish to encourage. For example, as discussed above, price caps may introduce disincentives to DSM by creating pressure to increase sales. Similarly, both price and revenue caps may discourage renewable resource procurement by pressuring utilities to seek resources with the lowest immediate cost. Such pressures in turn can increase the use of targeted incentive mechanisms to counter the effects of the broad-based mechanism. ${ }^{59}$

\subsubsection{Conclusion Regarding Performance-Based Ratemaking}

Many DR decisions ultimately will be driven by economics. PBR mechanisms and targeted incentives will influence these economics for both utilities and their customers. In general, PBR mechanisms will drive utilities to minimize cost. However, this trend to cost minimization may be tempered or even reversed in specific instances by the existence of targeted incentives and performance measures. To reach any definitive conclusions will require individualized analysis of the specific set of incentives provided to a specific project in a given jurisdiction.

\footnotetext{
${ }^{59}$ SDG\&E's PBR has specific provisions to counter any inherent incentive to reduce DSM spending. Moreover, SDG\&E's pre-existing targeted DSM incentive continued to operate after the adoption of the PBR mechanism. 55 CPUC $2 \mathrm{~d} 592$, 640-43 (D. 94-08-023, pp. 82-83).
} 


\section{ANTITRUST \& ANTICOMPETITIVE ISSUES FACING UTILTY DISTRIBUTED RESOURCE ACTIVITIES}

\subsection{INTRODUCTION}

Chapter 3 reviewed recent regulatory developments likely to affect the value of DR to energy suppliers and their customers, and thus their interest in pursuing DR activities. This chapter assumes that DR will offer substantial value under some conditions, and that regulated utilities (vertically integrated or otherwise) will be among those interested in pursuing DR strategies. It focuses on the question of whether utilities will be free to participate in DR markets as they wish, and to what extent antitrust and anticompetitive concerns may dictate the nature and form of their participation.

Antitrust and anticompetitive issues arise from the very nature of distributed resources. By definition, these resources are not utility central station plants whose economies of scale, scope, or integration historically have justified natural monopoly treatment by legislators and regulators. The hallmarks of such regulatory treatment are restriction of market entry (typically through exclusive service areas) to permit such economies to be realized, and regulation of prices to prevent monopoly abuses. Market entry restrictions are arguably irrelevant to $D R$, since most $D R$ facilities will not depend for their value on economies of scale or scope, but on features more characteristic of competitive technologies (such as small size, modularity, portability, and mass production economies). To the extent that $\mathrm{DR}$ are indeed competitive, natural monopoly price regulation is equally irrelevant, since a well-functioning market should check abuses without the need for price regulation.

Because DR do not fit easily within conventional natural monopoly concepts, some have questioned whether regulated utilities should be involved in their development and deployment at all, or if they should, how utility participation can be structured to prevent cross-subsidies from monopoly activities, or unfair use of monopoly assets to disadvantage competitors. These questions have been raised in both administrative and judicial proceedings, under general principles favoring competition and ratepayer protection, and under specific antitrust laws. Recent regulatory proceedings in which these issues have already arisen include, for example, Edison International's (then Southern California Edison's) application to establish an on-grid photovoltaic financing program, ${ }^{1}$ and Virginia Power's application for a "dispersed energy facility rate" for utility-owned cogeneration at large customer sites. ${ }^{2}$ Similar issues have also been addressed in commission and court cases involving fact situations analogous to DR, such as Pacific Gas \& Electric's 1994 application to provide competitive substation maintenance services using utility resources, ${ }^{3}$ programs by Public Service Company of Oklahoma and the Sacramento Municipal Utility District (SMUD) to lease, install, and maintain outdoor lighting, and by SMUD to install line drops to individual buildings across private property; ${ }^{4}$ and a program by Washington Natural Gas to sell vent dampers to its customers in competition with local retailers. ${ }^{5}$ Nor are these questions unique to the electric utility industry; they have been addressed at length in other regulated industries as well.

The remainder of this chapter reviews principles of antitrust and anticompetitive law bearing on these issues, and their application to circumstances similar to those presented by utility DR

\footnotetext{
'Southern Califomia Edison Advice Letter No. 1112-E filed July 10, 1995 with the Califomia Public Utilities Commission (CPUC); especially CPUC Division of Ratepayer Advocates July 31, 1995 protest letter.

2 Virginia State Corporation Commission Case No. PUE 930046; filed June 4, 1993; Final Order issued April $20,1995$.

${ }^{3}$ Pacific Gas \& Electric Company Advice Letter filing No. 1485-E filed October 31, 1994 with the California Public Utilities Commission, and the Commission's Resolution E-3404, August 11, 1995.

${ }^{4}$ Lease Lights, Inc. v. Public Service Company of Oklahoma, 849 F.2d 1330 (10th Cir. 1988); Grason Electric Co. v. Sacramento Municipal Utility District, 770 F.2d 833 (9th Cir. 1985), cert. denied, 474 U.S. 1103 (1986), reh'g denied, 475 U.S. 1091. See text accompanying note 21 below.
}

${ }^{5}$ Gatlin v. Washington Energy Co., 791 F.2d 1343 (9th Cir. 1986). See text accompanying note 70 below. 
activities. The chapter concludes that these principles and their application by courts, commissions, and legislatures are extremely important for those considering DR implementation: they will fundamentally shape the roles available to utilities and affiliated entities, and the business strategies that make sense for those interested in DR development.

\subsection{REGULATION \& ANTITRUST IN THE ELECTRIC INDUSTRY}

The goal of antitrust law is to protect the existence of competitive market conditions, allowing the efficient operation of market forces. As the electric industry becomes more competitive, antitrust law will play a more important role in influencing utility conduct. Utility participation in DR development is particularly likely to result in increased antitrust scrutiny, because of the potential for utilities to use their monopoly power in traditional, regulated markets to unfair advantage in emerging, competitive DR markets.

Electric utilities traditionally have been subject to pervasive administrative regulation to compensate for the perceived inadequacies of free markets in preventing potential abuse of monopoly power. In return for the grant of monopoly franchises, utilities have agreed to subject themselves to comprehensive price and service regulation. This pervasive regulatory scheme dominated during the first century of the electricity industry.

Antitrust law provides an alternative regulatory scheme that relies to a larger extent on the operation of free markets. Antitrust regulation is generally less intrusive than administrative regulation, allowing greater autonomy in day-to-day decision making, and intervening only when necessary to prohibit conduct that stifles competition. The high cost of litigation and the threat of triple damages for certain offenses enhances the deterrent effect of antitrust enforcement.

Regulation and antitrust law are not mutually exclusive. Although it seems contradictory, antitrust laws have long been applied to regulated industries, including the electricity industry. The application of antitrust laws to regulated utilities reflects the belief that the regulatory process can be manipulated to restrict competition, and that competition should be encouraged in areas not covered by regulation. ${ }^{6}$ Regulation is used to substitute for competition in areas where competition is inappropriate, as where natural monopoly conditions persist. Antitrust is used to protect competition in areas where competitive market forces can be expected to provide effective market regulation. ${ }^{7}$

The primary antitrust law of interest here is the Sherman Act, which prohibits monopolization and attempted monopolization, and has been held by some courts to prohibit conduct by a monopolist in one market that confers an unwarranted competitive advantage in a second market. The following describes the application of this and other antitrust laws to regulated utilities, beginning with exemptions from antitrust law that may be available for utility DR activities, and proceeding to liability theories that could be advanced where these exemptions are not available.

\subsection{ANTITRUST EXEMPTIONS FOR REGULATED CONDUCT}

It is commonly believed that utilities are exempt from the antitrust laws. While it is true that regulated utilities are sometimes immunized from antitrust liability if their conduct is authorized by statute or approved by regulators, this immunity has never been absolute. Moreover, its scope has been narrowed considerably in recent years. ${ }^{8}$ This section discusses the evolution of antitrust exemptions and their application to regulated utilities.

\footnotetext{
${ }^{6}$ P. Joskow, "Mixing Regulatory and Antitrust Policies in the Electric Power Industry: The Price Squeeze and Retail Market Competition," in ANTITRUST AND REgULATION: ESSAYS IN MEMORY OF JOHN J. MCGOWAN 178 (1985).

${ }^{7}$ J. Lopatka, "The Electric Utility Price Squeeze As an Antitrust Cause of Action," 31 U.C.L.A. L. Rev. 563 (1984).

8 P. Joskow (1985) at 182-83.
} 


\subsubsection{Immunity Under the 'State Action' Doctrine}

\section{Introduction}

The 'state action' doctrine exempts the actions of states acting in their sovereign capacity, and of private parties acting under state regulatory supervision, from federal antitrust scrutiny. The doctrine was developed to balance the federal interest in protecting competition with an individual state's interest in promoting distinctive economic, social, or political goals. It is highly relevant to utility participation in DR markets, because it goes to the question of the extent to which utilities, acting in furtherance of state legislative and regulatory policy, can use their substantial market power to competitive advantage in DR markets without running afoul of the federal antitrust laws. The following paragraphs review the development of the state action doctrine, and its application in the context of utilities participating in competitive markets.

In the first case to apply the state action doctrine, the US Supreme Court held that a California law establishing a cartel for the marketing of raisins did not violate the Sherman Act. ${ }^{9}$ Although the cartel was clearly anticompetitive, the Court focused on the issue of state sovereignty over economic regulation, and concluded that the federal government's legitimate interest in promoting competition did not preempt the state's interest in economic regulation.

More recent decisions applying the state action doctrine have struggled to develop a workable test that balances state and federal interests. The current formulation of this test, called the Midcal test, has two requirements:

(1) Clear Articulation: The challenged conduct must be "clearly articulated and affirmatively expressed as state policy;" and

(2) Active Supervision: The state policy must be "actively supervised" by the state itself. 10

The challenge for DR participants is to determine what kind of involvement by a public utility commission will constitute 'clear articulation' and 'active supervision' of utility DR activities that might appear to have anticompetitive elements. A number of cases, both inside and outside the utility context, provide guidance on this question. Regarding the 'clear articulation' requirement, the courts have said:

The state does not have to compel the anticompetitive conduct for immunity to apply. "A state policy that expressly permits, but does not compel, anticompetitive conduct may be 'clearly articulated' within the meaning of Midcal."11

A private party acting pursuant to an anticompetitive regulatory program does not have to point to specific, detailed legislative authorization for immunity to apply. Rather, a reference in a broad authorizing statute to a field or area of authority is enough. 12

The state legislature does not have to explicitly say that it expects a regulatory program to result in anticompetitive effects. Rather it is enough if the statute clearly contemplates anticompetitive activity, or if anticompetitive activity is a foreseeable result of the authority delegated. ${ }^{13}$

Taken together, these statements suggest that broad state legislative authorization that foreseeably could result in anticompetitive activity may be enough to satisfy the 'clear articulation'

\footnotetext{
9 Parker v. Brown, 317 U.S. 341 (1943).

10 California Retail Liquor Dealers Association v. Midcal Aluminum, Inc., 445 U.S. 97 (1980).

1 Southern Motor Carriers Rate Conference v. United States, 471 U.S. 48, 61 (1985); emphasis added.

12 Id., at 64; Town of Hallie v. City of Eau Claire, 471 U.S. 34, 42 (1985); emphasis added.

13 Town of Hallie v. City of Eau Claire, 471 U.S. at 42 (1985); emphasis added.
} 
requirement for antitrust immunity. Although not all courts agree with them, these interpretations (characterized by one commentator as "extraordinarily lenient"14) have made state delegations of regulatory authority more difficult to challenge on antitrust grounds.

\section{Application of the 'State Action' Doctrine to Utilities}

The starting point for describing the state action doctrine's application in the utility context is the US Supreme Court's 1976 decision in Cantor v. Detroit Edison Co. ${ }^{15}$ In Cantor, a retail pharmacist who sold light bulbs in his store sued Detroit Edison over its free light bulb exchange program that had been in place since before the turn of the century. The pharmacist claimed that the utility was using its monopoly power in the distribution of electricity to restrain competition in the sale of light bulbs.

Detroit Edison argued that the state action doctrine exempted the program from federal antitrust laws, because the Michigan Public Service Commission had approved the light bulb exchange program in a tariff. The Supreme Court, however, held that the Commission's approval of the tariff was not enough to constitute 'state action.' The Court reasoned that the light bulb exchange program was not required by the state; that the utility exercised sufficient freedom of choice to be held responsible for the consequence of its conduct; and that the utility could have abandoned the light bulb exchange program at any time by filing a new tariff.

The Cantor case also emphasized the difference between markets pervasively regulated by the state and those only peripherally regulated. The utility argued that antitrust laws should not be applied in areas pervasively regulated by state agencies. The Court rejected this argument, noting that "even if we were to assume that Congress did not intend the antitrust laws to apply to areas of the economy primarily regulated by a State, that assumption would not foreclose the enforcement of antitrust lows in an essentially unregulated area such as the market for electric light bulbs."16

Cantor teaches two important lessons regarding utility participation in DR markets. First, the case suggests that the state action doctrine is unlikely to immunize utility $D R$ activities that are purely voluntarily, rather than at the behest of state legislators or regulators. There are situations where utilities have engaged in arguably anticompetitive conduct as a result of legislative command, and in such situations utility conduct is likely to be immunized. Utility participation in demand-side management (DSM) programs is one prominent example. ${ }^{17}$ But where utilities take the initiative to participate in markets some regard as peripheral to their core regulated business, state action immunity is less likely.

Cantor's second lesson is that even in an industry subject to pervasive regulation, the courts will look at the character of the specific market in which anticompetitive conduct is alleged to determine whether the market is primarily regulated or primarily competitive. As the Court indicated, states are entitled to develop regulatory programs in which "the very purpose of the government control is to avoid the consequences of unrestrained competition."18 California's establishment of what amounted to a cartel for marketing raisins in the Parker case is one example. Another example would be a traditional electric utility function, such as providing regulated residential service, that clearly falls within the scope of the utility's monopoly franchise. But in markets where the state does not intend to supplant competition with regulation, incidental state regulation will not be granted the same deference. This suggests, for example, that a state statute

\footnotetext{
14 T. Jorde, "Antitrust and the New State Action Doctrine: A Return to Deferential Economic Federalism," 75 California I. Rev. 227, 235 (1987).

15428 U.S. 579.

16428 U.S. at 579; emphasis added.

17 See the discussion of Transphase Systems, Inc. v. Southern California Edison Co. accompanying note 26 below. 18428 U.S. at 579.
} 
requiring utilities to install backup generating systems in all hospitals at ratepayer expense may exempt the utility program from antitrust scrutiny, but a utility that executes the same program on its own volition, even if the program is approved by regulators, is unlikely to receive the same protection.

In Grason Electric Co. v. Sacramento Municipal Utility District (1985), ${ }^{19}$ the court applied the state action doctrine to a municipal utility. In that case a group of electrical contractors challenged the utility's participation in the market for construction of electrical equipment on private property (from utility pole to building), and in the market for street and outdoor lighting systems. The contractors argued that the utility's statutory authority to provide light, heat, and power did not extend to include the market for selling and installing electrical equipment on private property, and that the utility was using its monopoly power in the provision of retail service to gain an anticompetitive advantage in other markets. The utility argued that its participation in these markets was immunized by state action. The court agreed, holding that the 'clear articulation' requirement of the state action doctrine was satisfied by the broad delegation of authority to establish and operate municipal utilities contained in the California Constitution and state statutes.

Lease Lights, Inc. v. Public Service Company of Oklahoma (1988) ${ }^{20}$ was another case involving an outdoor lighting company's claims that a utility monopolized and/or attempted to monopolize the market for outdoor lighting. In this case, the utility (PSO) sold electricity and also sold and leased outdoor lights in Tulsa. The Oklahoma Corporations Commission (Commission) regulated the rates charged by PSO for leasing outdoor lights to the public and for providing electricity to competing lighting contractors. In 1975, the Commission ordered PSO both to reduce the rates charged for its outdoor lighting service and to restructure its rates to competing providers by replacing a flat annual fee with a metered rate. As a result, PSO reduced its own lease rates by about 4 percent, while substantially increasing the rates charged to contractors for electricity used by competing lighting services. The lighting contractors brought suit, arguing the Commission's order was the economic equivalent of an "atomic bomb."

The court, however, found that the alleged conduct was immune under the state action doctrine. First, with respect to the 'clear articulation' requirement, the court quoted the Oklahoma Constitution's grant of power to the Commission to regulate electric utilities as to "the production, transmission, delivery, or furnishing of ... electric current for light, heat or power."21 The court deemed this enough to conclude that state law clearly intended to supplant the market for leased outdoor lighting with active regulation by the Commission. ${ }^{22}$ Second, with respect to the 'active supervision' requirement, the court noted that the Commission had regulated the outdoor lighting market in Tulsa for twenty years, imposing service guidelines and closely regulating the rates charged for these services. Thus, the Commission closely supervised the outdoor lighting services provided by PSO and other utilities, satisfying the second element of the Midcal immunity test. ${ }^{23}$

In another state action case, a private hydroelectric power developer brought an antitrust action against an investor-owned utility, alleging the utility had used its monopoly power to drive the

${ }^{19}$ Grason Electric Co. v. Sacramento Municipal Utility District, 770 F.2d 833 (9th Cir. 1985), cert. denied, 474 U.S. 1103 (1986), reh'g denied, 475 U.S. 1091. The statutory provision in question stated that a municipality may "acquire, construct, own, operate, control, or use... works or part of works for supplying the inhabitants of the district... with light [and] power... and may do all things necessary or convenient to the full exercise of the powers herein granted." Cal. Pub. Util. Code $\S 12801$.

20849 F.2d 1330 (10th Cir.).

21849 F.2d at 1333.

22849 F.2d at 1334.

23 Another interesting element of Lease Lights is that the lighting companies alleged that PSO had an unfair advantage because, unlike private contractors, it was authorized to install lighting without a state or municipal license. However, the court reasoned that PSO did not cause these regulations to be adopted, and that PSO in any case is immune from liability because these regulations are once again clearly articulated and actively supervised by the government. 
developer out of business by lying about its power purchase obligations and imposing unreasonable or economically prohibitive conditions on the developer's interconnection plan. ${ }^{24}$ The Court held that state action did not immunize the utility's conduct because it was not "clearly articulated". What set this case apart from previous ones is that the court wanted specific legislative or regulatory authority for the challenged conduct, rather than simply a broad delegation of authority. For example, the court emphasized that the utility failed to offer any state statute, regulation, or other authority suggesting that the utility's conduct relating to the interconnection plan was a foreseeable result of state policy. On the other hand, the court did hold that the 'active supervision' requirement was met where the Public Utilities Commission had the power to review the utility's actions and previously had done so under similar circumstances, even though it had failed to exercise that power in this case.

Another case applying the state action doctrine to utility conduct was brought by a seller of thermal energy storage systems against two large investor-owned utilities in California. The company alleged that the utilities had conspired with one another and independently used their monopoly power to reduce rebates paid to customers using the plaintiff's DSM systems. The court found state action immunity and dismissed the case, concluding that the 'clear articulation' requirement was satisfied by a Public Utilities Code section that mandated a Commission-established bidding system for demand side services, and the 'active supervision' requirement was met by the Commission's published opinions showing its participation in all aspects of utility DSM activities. ${ }^{25}$

\section{Conclusions Regarding 'State Action' Immunity}

The cases discussed above indicate how courts might respond to possible antitrust challenges against utilities participating in DR development. They suggest that utilities will be able to claim state action immunity from federal antitrust claims only where (1) the state has clearly articulated and affirmatively expressed a desire to supplant competition with regulation in the development or deployment of particular DR technologies, and (2) the state has actively supervised the utility's participation in the relevant DR markets. The courts continue to struggle over whether a broad delegation of authority to regulate electric utilities, such as most states grant to their public utility commissions, will be enough to immunize anticompetitive conduct by utilities in competitive markets. Grason and Lease Lights suggest that immunity can be granted pursuant to a broad delegation of authority, while Cantor, Nugget, and Transphase suggest that a more specific grant will be required.

More generally, utilities are likely to find their conduct protected by state action immunity where there is evidence of market failure preventing the efficient operation of a competitive market for $D R$, and the state responds by making a conscious policy decision to actively promote and supervise utility participation in DR development. On the other hand, utilities are less likely to find their conduct immunized where regulators take more of a reactive than proactive approach to utility participation in DR markets by merely approving or acquiescing in utility DR activities. Stated differently, the doctrine is likely to protect activities that state legislators or regulators choose to encompass within the boundary of the monopoly franchise, and unlikely to protect conduct that is outside that boundary. That boundary will shift as restructuring proceeds, and will vary from state to state in any case. However, the trend towards greater competition is likely to shrink, rather than expand, the monopoly franchise, and many $D R$ markets are likely to be on the far side of that line.

Still, certain DR applications are more likely than others to fall within the boundary of the monopoly franchise. For instance, state policymakers may view certain DR applications as local transmission and distribution (T\&D) support technologies rather than as generation technologies. Examples might include a fuel cell installed at a substation operating near capacity that allows the

${ }^{24}$ Nugget Hydroelectric, L.P. v. Pacific Gas \& Electric Co., 981 F.2d 429 (9th Cir. 1992), cert. denied, 508 U.S. 908 (1993).

25 Transphase Systems, Inc. v. Southern California Edison Co., 839 F. Supp. 711 (C.D. Cal. 1993). 
utility to provide additional effective capacity while deferring or avoiding the cost of upgrading the substation, or a photovoltaic system installed on residential rooftop that reduces the customer's effective peak demand. Although these applications involve technologies that generate electricity, they provide substantial value to the local T\&D system and can reasonably be treated as local T\&D investments rather than generation investments. Because the distribution system is expected to remain part of the regulated monopoly franchise under virtually all restructuring scenarios (even with full retail wheeling), DR applications that can be characterized as local T\&D investments are the most likely to be actively endorsed by state policymakers, and therefore the most likely to be immunized from antitrust scrutiny under the state action exemption.

The most difficult state action immunity issues are those that arise when a utility obtains regulatory approval for a program that appears to fall clearly outside the monopoly franchise. For instance, regulators in several states recently have approved utility participation in the market for off-grid or 'remote' photovoltaic systems. ${ }^{26}$ Most of these programs were initiated by the utilities on their own volition, rather than at the behest of state regulators, so they may or may not be proceeding from a clear articulation of state policy that utilities should engage in photovoltaic commercialization. ${ }^{27}$ Yet these programs have been scrutinized and approved by regulators, with the utilities offering remote photovoltaic systems in accordance with a filed tariff rate. None of these programs have been formally challenged on antitrust grounds, although a group of non-utility photovoltaic providers in California aggressively opposed Southern California Edison's program, and succeeded in obtaining some significant changes in it. In situations like these, whether or not immunity will be granted will depend on state-specific law and case-specific facts.

\subsubsection{Express And Implied Immunity}

Just as the state action doctrine seeks to resolve potential conflicts between state economic regulation and federal antitrust laws, the doctrines of express and implied immunity seek to resolve potential conflicts between federal regulation and the antitrust laws. In both cases, the ultimate question is the same: whether the government intended for regulation to supplant competition (and therefore the antitrust laws, which protect competition) with respect to the challenged conduct. ${ }^{28}$

Federal statutes exempt the activities of some industries from antitrust scrutiny. The intent to displace competition is clear in these cases because Congress has expressly stated that certain activity is not subject to the antitrust laws. Examples occur in the areas of agriculture, insurance, shipping, and transportation. In other instances, Congress has expressly delegated to regulatory commissions and others the authority to immunize particular activity from antitrust enforcement. However, we have found no express exemptions likely to affect electric utility participation in DR markets.

A more difficult question is under what circumstances federal antitrust immunity should be implied. The general rule disfavors immunity because the antitrust laws represent bedrock national economic policy that should not be lightly abandoned. Congressional intent can override this rule, but the intent must be clear. The implied immunity issue usually arises where there is a contradiction between the regulatory system and the antitrust laws. Immunity is more likely where the regulatory agency has the power to authorize or require the allegedly anticompetitive conduct. Substantial regulation of an industry is not enough to imply immunity, and in a regulated industry the courts will ask whether immunity is necessary to make the regulatory scheme work. Even where immunity is

26 See California Public Utilities Commission, Resolution E-3367: Southern California Edison Company Requests Authorization to Offer, on an Experimental Basis, Off-Grid Photovoltaic Service as an Alternative to Line Extension (April 6, 1994); Idaho Power Company, Schedule No. 60, Solar Photovoltaic Service Pilot Program (September 3, 1992).

27 An exception is Arizona, where the Corporations Commission effectively required an investor-owned utility to play a role in photovoltaic development.

28 See ERNEST GELLHORN \& RICHARD J. PIERCE, REgulated INDUSTRIES 338 (1987). 
implied, it will be granted only to the minimum extent necessary. ${ }^{29}$ In short, "[o]nly where there is a plain repugnance between the antitrust and regulatory provisions will repeal be implied." 30

For antitrust immunity to be implied with respect to electric utility participation in DR markets, either Congress would have to amend the Federal Power Act or the FERC would have to enact rules under the Act that meet the requirements described above. Absent the federal government's determination that utility participation in DR development requires relief from the antitrust laws, perhaps in order to accomplish some overriding national goal, antitrust immunity in this area is unlikely to be implied. A couple of historical examples may illustrate this point.

In the telecommunications industry, a number of similar issues arose with respect to the Federal Communication Commission's regulation of AT\&T, when competing providers were attempting to break into the market for long distance telephone service and AT\&T was alleged to be using its control over network access to unfair competitive advantage. In one such case, ${ }^{31}$ AT\&T asserted that the FCC's regulatory control over its conduct rendered it immune from antitrust liability. The court concluded that while AT\&T was subject to considerable regulatory control and supervision, there was no indication that the Federal Communications Act intended to immunize AT\&T from the antitrust laws. Nor was the regulatory scheme to which AT\&T was subject so inconsistent with the antitrust laws as to require immunity. AT\&T was not subject to conflicting requirements, nor was it being held liable for decisions which were not its own business judgment. Moreover, the FCC did not sanction AT\&T's conduct with regard to interconnections nor dictate its interconnection tariffs. Thus, while certain actions might ultimately have been subject to agency review, the initial decisions were the product of AT\&T's private business judgment, and were not so heavily regulated as to remove them from AT\&T's control. "The mere pervasiveness of a regulatory scheme does not immunize an industry from antitrust liability for conduct that is voluntarily initiated."32

Similar cases in the electricity industry have led to the same result. Courts have denied immunity for rate filing under the Federal Power Act, ${ }^{33}$ for a price squeeze claim arising out of the relationship between the electric utility's filed wholesale and retail rates, ${ }^{34}$ and for a monopolization claim arising out of a utility's refusal to deal with communities seeking to municipalize their distribution systems. ${ }^{35}$ The Supreme Court's comment in Otter Tail Power v. United States is typical: "When [such decisions] are governed in the first instance by business judgment and not regulatory coercion, courts must be hesitant to conclude that Congress intended to override the fundamental national policies embodied in the antitrust laws." ${ }^{\text {36 }}$

Ultimately, claims of implied immunity will require an evaluation of the specific regulatory scheme involved and the administrative authority exercised pursuant to that scheme. The inquiry will focus on (1) whether the utility's conduct was required or approved by the regulatory commission, pursuant to its statutory authority, in a way that is incompatible with antitrust enforcement, ${ }^{37}$ and (2) whether these activities are so pervasively regulated "that Congress must be assumed to have forsworn the paradigm of competition." 38

29 GELLHORN \& PIERCE, REGULATED INDUSTRIES at 344-45.

${ }^{30}$ Gordon v. New York Stock Exchange, 422 U.S. 659 (1975).

${ }^{31}$ MCI Communications Corp. v. AT\&T, 462 F. Supp. 1072 (N.D. III. 1978).

32462 F. Supp. at 1086-87.

${ }^{33}$ City of Kirkwood v. Union Electric Co., 671 F.2d 1173 (8th Cir. 1982), cert. denied, 459 U.S. 1170 (1983).

${ }^{34}$ City of Mishawaka v. Indiana \& Michigan Electric Co., 560 F.2d 1314 (7th Cir. 1977), cert. denied, 436 U.S. 922 (1978)

35 Otter Tail Power Co. v. U.S., 410 U.S. 369 (1973).

36410 U.S. at 374 n.30.

${ }^{37}$ See, e.g., Gordon v. New York Stock Exchange, 422 U.S. 659 (1975).

38 See Northeastern Telephone Co. v. AT\&T, 651 F.2d 76, 82 (2d Cir. 1981). 


\subsubsection{Immunity Under the 'Noerr-Pennington' Doctrine}

The Noerr-Pennington doctrine ${ }^{39}$ exempts from antitrust liability efforts by businesses to solicit government action (including action by regulatory commissions) on their .own behalf, even where the requested action has the effect of reducing competition. The doctrine has been successfully asserted as a defense against allegations that a business seeking to protect its markets was violating the antitrust laws in doing so. The Supreme Court has reasoned in these cases that the desirability of public participation in government processes, even for selfish rather than 'public' reasons, outweighs any anticompetitive effects.

There are, however, limits to the ability of businesses to lobby on their own behalf. In one case, the Supreme Court said that where a campaign ostensibly directed toward influencing governmental action is a "mere sham" to cover what is actually nothing more than an attempt to interfere directly with the business relationships of a competitor, the application of the antitrust laws would be justified. 40 This "sham" exception to the Noerr-Pennington doctrine has been applied in other cases as well. 41

Another prominent case applying the Noerr-Pennington doctrine may be particularly relevant to electric utilities. In the Allied Tube case, a plastic conduit manufacturer alleged restraint of trade against a steel conduit manufacturer, after the steel manufacturer successfully lobbied developers of the National Electrical Code (NEC) to adopt code standards prohibiting the use of plastic conduit. The Supreme Court found Noerr-Pennington immunity inapplicable because the doctrine protects efforts to influence government action, while the NEC's standards-setting process is done by a private association. Thus, the steel manufacturer's lobbying was not an effort to influence government action but a private effort to restrain trade. 42

Allied Tube may have important implications for utility participation in developing interconnection standards for grid-integrated DR technologies. Because interconnection at the local transmission and distribution level is likely to remain part of the regulated monopoly franchise even with retail wheeling, utilities will continue to exercise substantial control over the standards for metering, interconnection, and other issues relevant to maintaining the integrity and reliability of the distribution system. However, in DR markets utilities will be competing with non-utility providers for the sale and servicing of DR equipment. Allied Tube suggests that utilities will not benefit from antitrust immunity for efforts to influence at least private standard-setting that might benefit them at their competitors' expense.

On balance, however, Noerr-Pennington is likely to favorably influence utility participation in DR development. Utilities can actively seek a prominent role in the commercialization of DR technologies, even if the particular programs and policies being advocated benefit the utilities at the expense of potential competitors for the provision of DR products and services. For instance, a utility might seek permission from a public utility commission or a state legislature to use monthly bill inserts to market DR technologies, or to sell DR equipment under its own name to take advantage of the utility's name recognition. Although the Noerr-Pennington doctrine would not protect the utility from antitrust liability for the activity itself, the utility would not be liable merely for the act of soliciting the favorable legislative or regulatory policy.

\footnotetext{
39 The doctrine is named after the two Supreme Court cases from which it emerged, Eastern R.R. Presidents Conference v. Noerr Motor Freight, Inc., 365 U.S. 127 (1961); and United Mine Workers v. Pennington, 381 U.S. 657 (1965).

${ }^{40}$ Noerr, 365 U.S. at 144.

41 See, e.g., California Motor Transport Co. v. Trucking Unlimited, 404 U.S. 508 (1972).

42 Allied Tube \& Conduit Corp. v. Indian Head, Inc, 486 U.S. 492 (1988). 


\subsection{WHERE ANTITRUST EXEMPTIONS DON'T APPLY: LIABILITY THEORIES UNDER FEDERAL ANTITRUST LAW}

The previous section described the principal exemptions that might be available to immunize utilities or their affiliates from antitrust liability. If none of these exemptions applies, utilities may find themselves defending against allegations that they have violated federal antitrust laws. This section discusses substantive antitrust claims arising under each of the major federal antitrust statutes, emphasizing those that are most likely to arise in the context of utility DR activities.

\subsubsection{Monopolization And Attempted Monopolization}

The most likely basis for challenging utility participation in DR markets is Section 2 of the Sherman Act, which prohibits monopolization, attempts to monopolize, and (in some jurisdictions) monopoly leveraging. ${ }^{43}$ Merely possessing a monopoly does not violate Section 2 ; only when a firm that has or is seeking monopoly power uses that power to unreasonably restrict competition is it potentially liable under Section 2 . The following discussion considers three possible Section 2 claims against utility participation in DR markets. The first two - monopolization and attempted monopolization - are well established as independent claims under Section 2 . The third and arguably the most relevant - monopoly leveraging - is a controversial theory that has been adopted by some courts and rejected by others.

\section{Monopolization}

A valid monopolization claim requires (1) possession of monopoly power in the relevant market; and (2) willful acquisition or maintenance of that power as distinguished from growth of development as a consequence of a superior product, business acumen, or historic accident. 44

\section{Market Definition}

The first step in analyzing a monopolization case is to define the 'relevant market.' This is particularly important because the outcome of monopolization cases often turns on the market definition. ${ }^{45}$ Markets are defined in both product and geographic terms. ${ }^{46}$

Product markets are defined in terms of product homogeneity, technological differences, and substitute products. ${ }^{47}$ As one court put it, "[d]efining a relevant product market is primarily a process of describing those groups of producers which, because of the similarity of their products, have the ability - actual or potential - to take significant amounts of business away from each other." 48

Geographic markets are defined in terms of transportation costs, legal restrictions, restrictions on information flows, available distribution networks, and the scope of relevant advertising media. ${ }^{49}$ A standard definition used by the Supreme Court is that the "relevant geographic market is the

\footnotetext{
4315 U.S.C. $\$ 2$ (1992).

44 Aspen Skiing Co. v. Aspen Highlands Skiing Co., 472 U.S. 585, 596 n.19 (1985) (quoting United States v. Grinnell Corp., 384 U.S. 563, 570-7.1 (1966)).

45 In United States v. Aluminum Co. of America, 148 F.2d 416 (2nd Cir. 1945), for example, the court excluded recycled aluminum and secondary ingot from its definition of the aluminum market, thereby increasing Alcoa's market share from about one-third to about 90 percent.

${ }^{46}$ See, e.g., M.A.P. Oil Co., Inc. v. Texaco, Inc., 691 F.2d 1303, 1306 (9th Cir. 1982).

${ }^{47}$ LAWRENCE A. SUllivan, HANDBOOK OF THE LAW OF ANTITRUST §§ 13-17 (1977).

48 U.S. Anchor Manufacturing, Inc. v. Rule Industries, Inc., 7 F.3d 986, 994 (11th Cir. 1993).

${ }^{49}$ Id. § 19.
} 
geographic area of effective competition in which the defendant's product is traded." 50 In cases involving regulated utilities, the geographic market depends on the nature of the allegations being raised. Where the claim involves a party trying to compete with the utility within its service territory, the geographic market historically has been defined as the utility's service territory. ${ }^{51}$ On the other hand, where the claim involves a party trying to identify a competitive alternative to purchasing power from the utility, the geographic market historically has been expanded to include the area where a customer can turn for alternative supplies. 52 .

In the DR context, where a utility is competing with non-utility firms for the sale of DR equipment and services in the utility's service territory, the geographic market is likely to be defined as the utility's service territory. However, where a utility affiliate that is unregulated and can operate outside of its regulated parent's service territory is competing with other non-utility firms for the sale and service of DR equipment, the geographic market will be larger - most likely the area in which the affiliate does business.

\section{Possession of Monopoly Power}

Once the relevant market for a DR product or service is defined, the next step in assessing a monopolization claim is determining whether the utility has monopoly power in that market.

Monopoly power is usually defined as the power to control prices or exclude competition. ${ }^{53}$ In unregulated industries, courts often use the percentage of the market held by the monopolist (called the 'market share') as a proxy for monopoly power. Monopoly power usually is inferred where statistical data reveal a market share of more than 70 to 80 percent. $^{54}$ In a regulated industry, however, courts acknowledge that reliance on market share statistics is an inaccurate or misleading indicator of monopoly power, and that market share should constitute at most a point of departure for assessing monopoly power. Instead, the analysis must focus directly on the regulated company's ability to control prices or exclude competition - an assessment that requires close scrutiny of the regulatory scheme. .55

One case said that in a regulated market it is appropriate to consider the effect of federal and state regulation on prices and entry, including interconnection, and that evidence that a utility has a larger market share is not sufficient to prove monopoly power if regulation prevented the utility from having the power to restrict competition. ${ }^{56}$ Other factors used in assessing monopoly power are the size of competing firms, barriers to entry, pricing trends and practices, technological superiority, and market performance with respect to prices and profits. .7

\footnotetext{
50 Paschall v. Kansas City Star Co., 695 F.2d 322, 327 (8th Cir. 1982).

51 For instance, in one case the court defined the relevant market as a utility's service area after concluding that "there is simply no more sensible geographic area to use in defining the market in which to measure [the utility's] power, for there is no other market in which [the utility] operates, or in which other firms can pose a realistic threat to [the utility]." Grason Electric Co. v. Sacramento Municipal Utility District, 571 F. Supp. 1504, 1523 (E.D. Cal. 1983), rev'd on other grounds, 770 F.2d 833 (1985), cert. denied, 474 U.S. 1103, reh'g denied, 475 U.S. 1091. at 1523.

52 For example, in Tampa Electric Co. v. Nashville Coal, 365 U.S. 320, 327 (1961) the relevant geographic market was the "market area in which the seller operates, and to which the purchaser can practicably turn for supplies."

53 See United States v. E.I. Du Pont De Nemours \& Co., 351 U.S. 377 (1956).

54 See, e.g., United States v. Grinnell, 384 U.S. 563, 571 (1966); American Tobacco Co. v. United States, 328 U.S. 781 , 797 (1946); Standard Oil Co. v. United States, 221 U.S. 1, 33 (1911).

55 MCI Communications Corp. v. AT\&T, 708 F.2d 1081, 1107 (7th Cir. 1982)

56 Id.

57 LAWRENCE A. SULLIVAN, HANDBOOK OF THE LAW OF ANTITRUST, at $\$ 22$ (1977). 


\section{Use of Monopoly Power}

Because having a monopoly is not by itself illegal, the next step in assessing a monopolization claim is whether monopoly power is 'willfully acquired or maintained.' Only where monopoly power has been acquired or used in ways that go beyond normal, honestly industrial business conduct will the courts find monopolization to be illegal. ${ }^{58}$ Among the behaviors deemed illegal are predatory conduct and exclusionary practices. Following are some examples of potentially prohibited conduct that might be alleged to result from utility participation in DR markets.

\section{Predatory Conduct}

Predatory conduct is defined as conduct that advances the monopolist's competitive position not by improving its market performance, but by injuring competitors in order to drive them out of the market, forcing them to compete less effectively, or keeping them out of the market to begin with. ${ }^{59}$ One form of predatory conduct arises where a monopolist uses revenues from monopoly markets to subsidize its operations in competitive markets, a practice called cross-subsidization. For example, in one case a retailer of gas appliances alleged that the local utility had attempted to monopolize the market by offering appliances to customers at a price below its own costs. ${ }^{60}$ In the Cantor case described earlier an electric utility that gave its customers free, ratepayer-subsidized light bulbs was accused of predatory pricing by a pharmacist who sold light bulbs at retail. 61

\section{Exclusionary Conduct}

Exclusionary conduct is conduct that has the effect of altering the structure of the relevant market in a way that inhibits competition, particularly by raising barriers to entry. ${ }^{62}$

Hurst (1981) provides two examples of potentially illegal exclusionary conduct associated with utility participation in solar energy development. ${ }^{63}$ His examples, which are based on landmark monopolization cases, are relevant to other DR technologies as well.

The first involves a utility selling solar energy systems at retail, where competing retailers might claim that the utility is taking advantage of its monopoly in the regulated market for conventional utility service to monopolize the market for solar energy systems. Hurst suggests that because the solar energy market is in its infancy, existing retailers could argue that the utility is anticipating demand and attempting to preempt the development of a new, competitive market in order to discourage potential competitors. ${ }^{64}$ Although the utility may well have legitimate justifications for entering the solar market, its conduct may still be considered exclusionary. In support Hurst quotes a famous case in which the Supreme Court said it "can think of no more effective exclusion than progressively to embrace each new opportunity as it opened, and to face every newcomer with new capacity already geared into a great organization, having the advantage of experience, trade connections and the elite of personnel." 65

\footnotetext{
58 See Alcoa, 148 F.2d at 429-30; see also Sullivan (1977), at § 33.

59 Sullivan (1977), at § 43.

60 Southern Blowpipe \& Roofing Co. v. Chatianooga Gas Co., 360 F.2d 79 (6th Cir. 1966), cert. denied, 393 U.S. 844 (1968).

61 See text accompanying note 16 above.

62 SULLIVAN (1977), at $\$ 36$.

63 Thomas R. Hurst, "Antitrust Aspects of Involvement by Utilities in Residential Solar Energy," 16 Natural Resources Lawyer 511 (1981).

64 Hurst (1981) at 512.

65 Aluminum Company of America v. United States, 148 F.2d 416 (2d. Cir. 1945). Compare Cal. Public Utilities Code $\$ 2775.5$, especially subsection (b), directing the state's Public Utilities Commission to deny authorization for utility 48 solar energy programs which it finds will restrict competition or growth in the solar energy industry "or unfairly employ 
Hurst's second example of exclusionary conduct arising from utility participation in solar energy development involves a utility's leasing of solar energy systems to residential customers. He argues that competing retailers might claim that the utility was using its superior financial position, derived from its regulated monopoly operations, to exclude marginally capitalized companies from the solar business. Hurst bases this argument on a case in which the court found a shoe manufacturer's practice of leasing rather than selling its equipment to constitute exclusionary conduct. ${ }^{66}$ Although a utility could argue that customers benefit from having the option of leasing as well as purchasing the equipment, Hurst points out that the court in United Shoe rejected a similar argument because it found the exclusionary effect outweighed the benefits of long-term leasing. ${ }^{67}$ Interestingly, one investor-owned utility offering remote photovoltaic systems to off-grid customers has marketed its systems through a long-term lease program similar to the one criticized by Hurst. ${ }^{68}$

\section{An Electric Utility 'Monopolization' Case}

Many of the monopolization issues discussed above were raised in Catlin v. Washington Energy Co. ${ }^{69}$ This case involved a natural gas utility that began selling vent dampers ${ }^{70}$ in competition with local retailers. The retailers alleged that Washington Natural Gas ("WNG") had abused its monopoly power in the natural gas market, in violation of Section 2 of the Sherman Act. The utility had allowed its merchandising division exclusive use of WNG's customer list, and had printed advertisements for its vent dampers on bill envelopes sent to 217,000 residential gas customers in three counties. WNG conceded that the costs of mailing the bills were included in rates paid by its natural gas customers, indicating that the utility was using revenues from its regulated business (natural gas sales) to cross-subsidize its operations in a competitive business (vent damper sales). However, the court found that WNG did not abuse its lawfully obtained monopoly power in the natural gas market, noting the legal distinction between "willful acquisition and maintenance" of monopoly power and "growth or development as a consequence of a superior product, business acumen, or historic accident."71 The Court concluded that WNG's merchandising division merely "benefits from association with a division possessing a monopoly in its own market," which does not violate the Sherman Act.

\section{Attempted Monopolization}

Attempted monopolization cases arise where monopolization is threatened, but has not yet been accomplished.72 A valid attempted monopolization claim under Section 2 must show (1) a specific intent to monopolize a relevant market; (2) predatory or anticompetitive conduct; and (3) a dangerous probability of success. ${ }^{73}$ Allegations of attempted monopolization often parallel and duplicate monopolization charges. Nevertheless, they require different kinds of evidence. In general, attempted monopolization will focus more on conduct and less on the existence of market power.

... any financial, marketing, distributing, or generating advantage which the [utility] may exercise as a result of its authority to operate as a public utility."

66 United States v. United Shoe Machinery Corp., 110 F. Supp. 295 (D. Mass. 1953), aff'd per curiam, 347 U.S. 521 (1954).

67110 F. Supp. at 344-45.

68 See Idaho Power Company, Schedule No. 60, Solar Photovoltaic Service Pilot Program (September 3, 1992).

69791 F.2d 1343 (9th Cir. 1986).

70 Vent dampers are "energy saving devices installed on flue pipes of oil or gas-fired furnaces and water heaters." $791 \mathrm{~F} .2 \mathrm{~d}$ at 1344.

71791 F.2d at 1347 (quoting United States v. Grinnell, 384 U.S. 563, 570-71 (1966)).

72 Alaska Airlines, Inc. v. United Airlines, Inc., 948 F.2d 536, 542 (9th Cir. 1991), cert. denied 503 U.S. 977 (1992).

${ }^{73}$ Alaska Airlines, 948 F.2d at 542 (citing Catlin, 791 F.2d at 1348). 
However, even this difference has narrowed considerably since a recent Supreme Court decision ${ }^{74}$ suggesting that a firm cannot be guilty of attempted monopolization unless there is some indication that monopoly power is present or immediately threatened.

The cases provide little guidance for assessing an attempted monopolization claim arising from utility participation in DR markets. The Supreme Court recently has eliminated much of the distinction between monopolization and attempted monopolization claims. An attempted monopolization claim against a utility would need to establish that the utility has engaged in anticompetitive conduct with a specific intent to monopolize the $\mathrm{DR}$ market and a dangerous probability of achieving a monopoly in that market. Although an attempted monopolization claim may succeed without a showing of actual monopolization, the 'dangerous probability' element will require proof that the utility possesses a significant market share.

\subsubsection{Related Doctrines}

\section{The 'Essential Facilities' Doctrine}

The 'essential facilities' doctrine is an exception to the rule that a firm with lawful monopoly power has no general duty to help its competitors. The doctrine is a special case of a line of monopolization cases involving dominant firms that refuse to deal with competitors in order to create or maintain their monopoly position. The doctrine has important implications for utility DR activities because it limits utilities' ability to restrict access to essential utility facilities (arguably including the distribution system) when such access is sought by competing DR providers.

Although the doctrine emerged outside the utility context, many recent essential facilities cases have involved competitors seeking access to facilities owned and controlled by regulated utilities. In the telecommunications industry, for instance, the leading case involved MCI's efforts to gain access to AT\&T's local networks and switching equipment, which was needed to connect MCI's customers to its independent long distance transmission facilities. ${ }^{75}$ In the electricity industry, the leading case involved an investor-owned utility's refusal to use its electric transmission facilities to wheel power to towns within its service territory that were seeking to municipalize their distribution systems. ${ }^{76}$

Application of the 'essential facilities' doctrine (or 'bottleneck' doctrine as it is sometimes called) requires proof of four elements: (1) control of an essential facility by a monopolist; (2) a competitors' inability to reasonably duplicate the essential facility; (3) the denial of use of the facility to a competitor; and (4) the feasibility of providing the facility. ${ }^{77} \mathrm{~A}$ recent case has suggested the addition of a fifth element, the failure to provide a reasonable business justification for denying access or for imposing excessively burdensome conditions on access. ${ }^{78}$

Gellhorn \& Kovacic (1994) have suggested that sensible application of the essential facilities doctrine must meet three requirements. First, the facility must be truly 'essential' to competitors and not just convenient or less expensive. Second, the monopolist's justifications for denying or restricting access must be considered and accounted for. Third, if the court determines that the facility is indeed 'essential,' the competitor must be required to cover the full cost of providing access. ${ }^{79}$ The following paragraphs take a closer look at each of these requirements.

\footnotetext{
74 Spectrum Sports v. McQuillan, 506 U.S. 447 (1993).

${ }^{75}$ See MCI Communications Corp. v. American Telephone \& Telegraph Co., 708 F.2d 1081 (7th Cir. 1983).

76 See Otter Tail Power Co. v. United States, 410 U.S. 366 (1973).

77 See MCI Communications Corp. v. American Telephone \& Telegraph Co., 708 F.2d 1081 (7th Cir. 1983).

78 See Aspen Skiing Co. v. Aspen Highlands Skiing Corp., 472 U.S. 585 (1985).

${ }^{79}$ E. GELlHORN \& W. Kovacic, ANTITRUST LAW AND ECONOMCS 151-52 (1994).
} 
Essentiality: Competitors must show that they are 'practically or reasonably' unable to duplicate the facility. It is not enough to argue that duplication will impose a cost disadvantage or reduce profits. The competitor "must show more than inconvenience, or even some economic loss; he must show that an alternative to the facility is not feasible." 80 In the regulated utility context, courts have tended to presume that assets such as pipelines and transmission lines are essential facilities, shifting the burden to the utility to rebut the presumption. ${ }^{81}$

Two cost-based standards have been developed for determining essentiality. The first compares the cost of wheeling over the monopolist's facility to the cost of bypass. If the cost of building a transmission line to an alternative supplier exceeds the cost to wheel power over the utility's transmission lines, the court is likely to conclude the facility is 'essential. ${ }^{282}$ The second cost-based standard compares the cost of bypass to the nearest alternative wholesaler, plus that wholesaler's cost of power, to the bundled wholesale rate offered by the local utility. ${ }^{83}$

Some commentators have endorsed these cost-based tests as "desirable efforts to measure essentiality"84 and an improvement over a conclusive presumption that utility facilities are essential. Others have criticized them because prevailing access prices, such as an unbundled access rate, may be set at artificially low levels by regulators who use embedded costs rather than current construction costs to calculate the rate, or because utilities may seek to price their wholesale bundled rates at a level just below the cost of bypass. ${ }^{85}$

An interesting aspect of the essentiality issue is that the commercialization of some DR technologies actually could bolster utility arguments that transmission and distribution network access is not essential. In particular, further technical innovation and cost reduction in technologies that encourage stand-alone generation (particularly storage technologies) could make the concept that network access is essential an anachronism. There are signs of this already in the telecommunications industry, where wireless technologies may make it possible to completely bypass the existing wireline network. In the electric industry, network bypass is theoretically easier to achieve because there is no inherent benefit in network interconnection, and the existence of the network is based entirely on economies of scale. In telecommunications, by contrast, interconnectivity is the essence of the technology, since the purpose is to communicate with others.

Justification: A determination of essentiality does not necessarily result in an obligation to wheel, if the utility owner of an essential facility can support its decision to deny or condition access by providing a reasonable business justification. In Otter Tail Power Co. v. United States (1973), for example, the Supreme Court noted that it was important to consider the utility's assertion "that compulsory interconnection or wheeling will erode its integrated system and threaten its capacity to serve adequately the public." ${ }^{266}$ Other courts have upheld the legitimacy of conditions on access or even denials of access on such grounds as failure to resolve legitimate engineering concerns, failure to specify timing for a wheeling transaction or the quantity of power to be wheeled, and other goodfaith efficiency concerns on the part of the facility owner. ${ }^{87}$

\footnotetext{
${ }^{80}$ Twin Laboratories, Inc. v. Weider Health \& Fitness, 900 F.2d 566, 570 (2d Cir. 1990).

81 W. Kovacic, "The Antitrust Law and Economics of Essential Facilities in Public Utility Regulation," in Econome INNOVATIONS IN PUBLIC UTUITY RegUlation 1, 5 (M. Crew, ed. 1992).

82 See City of Chanute v. Kansas Gas \& Electric Company, 564 F. Supp. 1416 (D. Kan. 1983), rev'd in part, aff'd in part, 754 F.2d 310 (10th Cir. 1985); Borough of Lansdale v. Philadelphia Electric Co., 692 F.2d 307 (3d Cir. 1982).

83 See Town of Massena v. Niagara Mohowk Power Co., 1980-2 Trade Cas. (CCH) Para. 63,526 (N.D. N.Y 1980).

84 Kovacic (1992) at 6.

85 Kovacic (1992) at 6-7.

86 Otter Tail, 410 U.S. at 381.

87 Kovacic (1992) at 8 (citing cases). 
Some courts also have found denial of access justified on grounds of equity rather than efficiency. For example, in City of Anaheim v. So. California Edison (1992) the court upheld Edison's refusal to wheel cheap hydroelectric power from the Pacific Northwest to municipal distribution systems in Southern California. The court noted that the municipalities would benefit at the expense of Edison's other customers, and concluded that although the municipalities "seem to contend that Edison has to disable itself so that they can get cheap power ... [t] the law requires no such thing."88

Justification arguments may be more difficult in the DR context, where a variety of studies have shown that distributed generation can provide direct, measurable economic benefits to the utility network. However, just as there are locations where the value of DR is particularly high, there are going to be places where its value is particularly low, and possibly negative. In such cases there may well be good business justification for denying or heavily conditioning access.

Remedy: Where courts decide to mandate access to essential utility facilities, they must also contend with the problem of determining appropriate terms and conditions. Because courts are illequipped to decide how to price access to the facility, their usual solution is to assign responsibility for setting and enforcing rates to the appropriate regulatory agency, based on guidance provided by the court's decision. This generally is considered superior to maintaining continuous judicial oversight, but it raises difficult questions regarding the agency's potentially conflicting responsibilities to carry out the court's proposed remedy while fulfilling its broader regulatory responsibilities. For instance, should regulators limit their decision to a consideration of the antitrust issues addressed by the court, or should they base their decision on a broader set of policy considerations that the agency may be statutorily required to consider in its decisions? Because so few courts have addressed these concerns, this issue remains unresolved. ${ }^{89}$

Implications of the Essential Facilities Doctrine for $D R$. The 'essential facilities' doctrine has important implications for utility DR activities. The doctrine is likely to be invoked by parties seeking to prevent integrated utilities from gaining monopoly power in downstream markets by denying or unfairly restricting potential competitors' access to those markets. For example, an electricity provider that holds a monopoly franchise in one market segment while facing vigorous competition in a downstream segment might be expected to use whatever tools are available including control of an essential facility - to discourage competition. In the DR context, the essential facility is likely to be the transmission or distribution system. The terms of access to these facilities may be established through the regulatory process, as with FERC rules requiring utilities to provide open-access tariffs for interstate transmission. But to the extent that regulators either fail to address the issue of access to essential facilities, or address it without adequately resolving antitrust concerns over the denial of access to competitors, the essential facilities doctrine is likely to be a powerful weapon in the arsenal of emerging competitors in the electricity industry.

\section{The 'price squeeze' doctrine}

Another liability theory related to Sherman Act Section 2 monopolization claims is known as the 'price squeeze' doctrine. This refers to a pricing practice where a firm, operating at two different levels of an industry in which its customers at the wholesale level are also its competitors at the retail level, designs its wholesale and retail prices to impede the wholesale customers' ability to compete with it for retail sales. The 'price squeeze' doctrine is potentially important for utility participation in DR markets because under certain unbundled rate scenarios, some could argue that utilities will be in a position to structure their rates to discourage DR development by competitors.

In the electric industry, 'price squeeze' cases usually have involved a private, investor-owned utility that sells power to retail customers as well as to wholesale customers. In these cases, the wholesale customer (usually a municipal distribution utility) has complained that the wholesale prices

88955 F.2d 1373, 1381 (9th Cir. 1992).

${ }^{89}$ Kovacic (1992) at 12. 
it is charged are too high, relative to the prices charged to the selling utility's retail customers, to permit it to compete for those retail sales. The effect of this 'price squeeze' may be to discourage retail customers from locating in the municipal utility's service territory, or to discourage the municipal utility from expanding its service territory. Ultimately, competitive pressure from retail customers could result in the collapse of the municipal utility, usually to the private utility's benefit.

The fact that the private utility's rates are regulated at both wholesale and retail levels complicates the utility 'price squeeze' case, because effective price regulation presumably would avoid any anticompetitive harm. Some courts have suggested that a price squeeze may be illegal even where prices are regulated at both levels, ${ }^{90}$ but a more recent case, Town of Concord, Massachusetts $v$. Boston Edison Co. (1990), ${ }^{91}$ concludes that under most circumstances price regulation at both levels will prevent a price squeeze from constituting an exclusionary practice of the type prohibited by Sherman Act Section 2.92

For present purposes, the most important price squeeze issue may be the one that arises where a utility regulated at one level uses a price squeeze to dominate at a second, unregulated level. This is the issue most likely to arise with utility participation in DR development. Even the Boston Edison court, in rejecting the regulated price squeeze argument, acknowledged that:

our reasoning applies with full force only when the monopolist who engages in the squeeze is regulated at both industry levels. We recognize that a special problem is posed by a monopolist, regulated at only one level, who seeks to dominate a second, unregulated level, in order to earn at that second level the very profits that regulation forbids at the first. ${ }^{93}$

Neither the courts nor the leading antitrust analysts have provided much guidance regarding the implications of the 'price squeeze' doctrine for utility participation in unregulated markets. The issue is most likely to arise where a utility sells to competitors an essential element of a product or service that the utility and its competitors sell at retail. One example that might arise in a post-restructuring environment would be a utility providing interconnection service (standby or backup power) to a commercial customer who plans to self-generate using a fuel cell. Assume that the utility retains its monopoly control over the distribution system, and the utility also participates in the competitive market for fuel cells. The utility's rates for standby service are regulated, but the utility's prices for fuel cells are unregulated. This allows the utility to offer its own fuel cell, bundled with its standby service, at an unregulated price. If the utility were to take advantage of the regulatory regime to charge an artificially high price for standby service to the competing fuel cell retailer, while offering its own bundled fuel cell/standby service at a lower price, it might be vulnerable to claims of driving the competitor out of business in order to monopolize the market.

\subsubsection{Monopoly Leveraging}

\section{The Monopoly Leveraging Theory}

Among the antitrust claims which utilities implementing DR might face, "monopoly leveraging" may have the greatest reach. Monopoly leveraging has been defined as a monopolist's use of its power in its own market to control activities in another market. ${ }^{94}$ In the DR context, the issue

90 See, e.g., City of Kirkwood v. Union Electric Co., 671 F.2d 1173 (8th Cir. 1982), cert. denied, 459 U.S. 1170 (1983); City of Groton v. Connecticut Light \& Power Co., 616 F.2d 976 (2d Cir. 1981); City of Mishawaka v. American Electric Power Co., 616 F.2d 976 (7th Cir. 1980), cert. denied, 449 U.S. 1096 (1981).

91915 F.2d 17 (1st Cir.)

92915 F.2d at 22-23.

93915 F.2d at 29 (citing 3 P. AREEDA \& D. TURNER, ANTITRUST LAW $1726 e$, at 217-220 (1978)); emphasis added. See also the discussion of Alaska Airlines, Inc. v. United Airlines, Inc. later in this section.

94 L. Kaplow, Extension of Monopoly Power Through Leverage, 85 Columbia L. Rev. 515,516 (1985). 
could arise from attempts to leverage utility monopoly power in regulated markets to gain unfair advantage in competitive markets for DR technologies and services. .5

Courts have held that monopoly leveraging has five elements: (1) monopoly power in a relevant market; (2) challenged activities in a defined second market; (3) use of monopoly power, as opposed to other advantages the monopolist enjoys by virtue of size, integration, etc., (4) unwarranted competitive advantage in the leveraged market; and (5) actual injury caused by the challenged activity. 96 The fourth element just listed - "unwarranted competitive advantage" - is what primarily distinguishes monopoly leveraging from conventional monopolization and attempted monopolization claims under the Sherman Act. This element implies a broader and less rigorous standard of proof that may fall considerably short of what would be required to establish monopolization or attempted monopolization claims under the case law discussed above. The availability of this looser standard could significantly expand antitrust exposure for utilities which choose to participate in DR markets.

The distinction between monopoly power and competitive advantage in the second market is especially important for utility DR participation. Establishing monopoly power typically requires a showing of substantial market share:97 under this traditional test, utilities will not be in violation of antitrust law unless they are dominating the second market. Establishing an unwarranted competitive advantage, on the other hand, is a much lower threshold requirement: it focuses more on the utility's conduct than on the structure of the market. Under this newer test, a utility could be found liable for monopoly leveraging even if its share of the second market is insignificant.98

Monopoly leveraging has been a controversial area of antitrust law, and federal court decisions are in conflict regarding its validity as an independent basis for a Sherman Act Section 2 violation. Some courts recognize the claim when the elements listed above are present. Others reason that monopoly leveraging is just a special case of monopolization or attempted monopolization and that, as required for those claims, there must be a showing of monopoly power in the second market rather than merely an unwarranted competitive advantage in that market. However, even one of the leading cases that invoked this reasoning to reject monopoly leveraging as an independent ground of liability emphasized that its conclusion might well be different if the monopolist were a regulated monopolist. ${ }^{99}$ Until the conflict among the courts over monopoly leveraging in general is resolved probably by the Supreme Court - and until the specific question of monopoly leveraging by a regulated monopolist is addressed, this area of the law will remain in flux, and will warrant continuing attention by utilities pursuing DR activities.

\section{The Origins of Monopoly Leveraging}

The monopoly leveraging theory developed in Berkey Photo, Inc. v. Eastman Kodak Co. (1979). ${ }^{100}$ When the case was brought, Kodak controlled about 60 percent of the camera market and over 80 percent of the film market, giving it substantial market power in those areas. Kodak also participated in a number of other markets, which it did not dominate to the same extent. Berkey was

\footnotetext{
95 Hurst (1981) at 512.

96 Catlin, 791 F.2d at 1349 (quoting Grason Electric Co. v. Sacramento Municipal Utility District, 571 F. Supp. 1504, 1518-19 (E.D. Cal. 1983)); but see Alaska Airlines, 948 F.2d at 546 (describing monopoly leveraging as having "only two rather loose elements:" that there be monopoly power in some market, and that such power be exercised to the detriment of competition in another market.)

97 See discussion of monopolization and attempted monopolization earlier in this section.

${ }^{98}$ Perhaps to reconcile these quite different standards, some courts have effectively split the difference, requiring a showing of "tangible harm to competition" in the second market. See, e.g., Twin Laboratories, Inc. v. Weider Health \& Fitness, 900 F.2d 566. 571 (2d Cir. 1990).

99 See text accompanying note 109 below.

100603 F.2d 263 (2d Cir.), cert denied, 444 U.S. 1093 (1980).
} 
a competing provider of photofinishing services, an area in which Kodak clearly did not have monopoly power. Berkey filed suit, arguing that Kodak used its power in the camera and film markets to gain an unfair advantage in the photofinishing market. Berkey acknowledged that Kodak did not attempt to monopolize the photofinishing market. The court concluded that a firm could violate Section 2 by using its monopoly power in one market to gain a competitive advantage in another, even where there is no attempt to monopolize the second market. The fact that competition in the leveraged market "may not be destroyed but merely distorted does not make it more palatable."101

On the other hand, the Berkey court emphasized that not all use of economic power creates antitrust liability. In a passage of central importance to utilities considering participating in DR markets and other competitive markets, the court said:

[A] large firm does not violate Section 2 simply by reaping the competitive rewards attributable to its efficient size, nor does an integrated business offend the Sherman Act whenever one of its departments benefits from association with a division possessing a monopoly in its own market. So long as we allow a firm to compete in several fields, we must expect it to seek the competitive advantages of its broad-based activity - more efficient production, greater ability to develop complementary products, reduced transaction costs, and so forth. These are gains that accrue to any integrated firm, regardless of its market share, and they cannot by themselves be considered uses of monopoly power. ${ }^{102}$

The tension between the court's basic holding and this 'integrated business' exception is important in applying the doctrine in the utility context. The utility leveraging cases discussed below repeatedly raise the question whether the utility's conduct in a particular competitive market constitutes an unfair competitive advantage, or whether the utility merely is benefiting from the competitive advantages of being a large, integrated business. ${ }^{103}$ Ultimately, the courts have concluded in most cases that the challenged utility's conduct falls within the integrated business exception, but considerable uncertainty remains regarding this important point.

\section{Monopoly Leveraging In Practice}

In Alaska Airlines, Inc. v. United Airlines, Inc. (1991), ${ }^{104}$ the Ninth Circuit rejected monopoly leveraging as an independent basis for liability under the Sherman Act. The case involved a lawsuit by four smaller airlines against two of their largest competitors, United Airlines and American Airlines, who ran the only available computerized reservation systems (CRS) for planning air travel. The smaller airlines alleged that the larger carriers were leveraging their dominance in the computerized reservation systems (CRS) market in order to gain an advantage in the air travel market. In rejecting the smaller airlines' claim, the court emphasized the distinction between legal and illegal monopolies, and described two categories of legal monopolies. The first was efficient monopolies:

A firm may acquire a monopoly simply by virtue of being a better competitor. For example, a firm may have better production methods or be more innovative than its past and prospective competitors. This kind of monopoly, absent "predatory" practices to maintain it, will continue only so long as the monopolist sustains a level of efficiency or innovation such that its rivals cannot effectively compete. 105

\footnotetext{
101603 F.2d at 275.
}

102603 F.2d at 276.

103 Similar language was used in distinguishing 'good' or 'efficient' monopolies from illegal ones in United States v. Grinnell Corp., 384 U.S. 563, 570-71 (1966). In that case, the Supreme Court noted that Section 2 did not prohibit "growth or development as a consequence of a superior product, business acumen, or historic accident."

104948 F.2d 536 (9th Cir.), cert. denied, 503 U.S. 977 (1992).

105 Alaska Airlines, 948 F.2d at 547 (citations omitted). 
The second category of legal monopolies was natural monopolies, which arise when there is not enough room in the market to support more than one firm. The court noted that public utilities supplying electricity, gas, water and telephone services were usually regarded as classic examples. ${ }^{106}$

The Alaska Airlines court concluded that the Sherman Act does not prohibit a monopolist having a lawful monopoly in one market from using its power merely to gain a competitive advantage in the second market. "Unless the monopolist uses its power in the first market to acquire and maintain a monopoly in the second market, or to attempt to do so, there is not a Section 2 violation." 107 In fact, the court described monopoly leveraging as one of a number of ways that a monopolist can permissibly benefit from its position. However, it also included the following footnote to its decision that seems especially noteworthy in the DR context:

We highlight that this case does not involve the special problem of a regulated monopolist (usually a natural monopolist) that seeks to evade regulations which limit profits in the monopoly market by creeping into adjacent, unregulated markets. Such a case might present very different issues. ${ }^{108}$

In any event, the distinction between efficient or natural (and therefore legal) monopolists and illegal monopolists has come up in a number of leveraging cases involving regulated utilities. Two of these cases are discussed next.

In Catlin v. Washington Energy Co. (1986), 109 discussed above with respect to its monopolization and attempted monopolization claims, the retailers also asserted a monopoly leveraging claim. ${ }^{110}$ The Catlin court concluded that the retailers' monopoly leveraging claim had to be rejected because they had "failed to prove that WNG's marketing activity was an abuse of monopoly power rather than an advantage of size and integration."111

Grason Electric Co. v. Sacramento Municipal Utility District (1983), ${ }^{112}$ described earlier in connection with state action immunity, involved a claim by electrical contractors that SMUD had unlawfully used its monopoly power in the retail electricity market to compete unfairly for work installing and maintaining street and outdoor lighting systems, and to preclude them from installing connections from utility distribution lines to buildings across private property. The contractors alleged that SMUD's rate structures favored SMUD-owned and maintained systems over privately owned and maintained systems. For example, developers and others could have outdoor lighting systems installed by SMUD at no initial charge because SMUD absorbed the installation costs into its rate structure and recovered them via monthly charges to customers participating in the program. ${ }^{113}$

The court denied the contractors' leveraging claim on the same grounds relied on by the Catlin court: it concluded that SMUD's use of power in this market was not a use of monopoly power, but a consequence of its size, noting Berkey's distinction between unlawful use of monopoly power and lawful advantage associated with size, integration, foresight, and business acumen. ${ }^{114}$

\footnotetext{
${ }^{106}$ Alaska Airlines, 948 F.2d at 548 (quoting P. AREEDA \& D. TURNER, ANTITRUST LAW 47-48 (1978). There is, of course, widespread acknowledgment just a decade after Alaska that at least some segments of the public utility industry no longer exhibit natural monopoly characteristics. See, e.g.; Town of Concord, Massachusetts v. Boston Edison Co., 915 F.2d 17, 31 (1st Cir. 1990) (noting the "growing conviction among students of the subject that the electricity generation business (as opposed to the transmission and distribution business) may be able to support several competing firms.")

107948 F.2d at 548.

108948 F.2d at 549, n.17. The court expressed a similar concern in Town of Concord v. Boston Edison Co., supra note 106.

109791 F.2d 1343 (9th Cir.)

110 The factual situation in Catlin was described in the previous section discussing monopolization.

111791 F.2d at 1348.

112571 F. Supp. 1504 (E.D. Cal. 1983).

113571 F. Supp. at 1511.

114571 F. Supp. at 1528 (citing Berkey, 603 F.2d at 274-76, 281, 283, 291 \& 291 n.50).
} 
These cases suggest that where monopoly leveraging claims are brought against electric utilities participating in DR development, the courts are going to focus on whether regulated utilities properly should be considered 'natural' or 'efficient' monopolists. Regulated utilities are assumed to have natural monopolies in their regulated markets - after all, that is the traditional justification for granting utilities their monopoly franchises. But there is no evidence that these natural monopoly characteristics carry over into secondary markets for DR technologies. The same reasoning applies to 'efficient' monopolies: there is little reason to presuppose that regulated utilities are better competitors, have more efficient production methods, or are more innovative than prospective competitors. In fact, regulated utilities frequently have been condemned for being bureaucratic, inefficient, and slow to respond to industry innovations. ${ }^{115}$ Yet in both Catlin and Grason, the courts found that the utility was subject to the 'integrated business' exception, in that it was benefiting from its size, efficiency, and integration of different markets rather than its monopoly power.

\subsubsection{The "Tying" Doctrine Under The Sherman And Clayton Acts}

A utility initiative that appears to link a monopoly product or service with a competitive DR offering could be subject to challenge under federal antitrust laws as an illegal tying arrangement. A tying arrangement is a requirement by the seller that a customer wishing to purchase one product from him (the tying product) must also purchase another product from him (the tied product). ${ }^{116}$ Tying arrangements are prohibited under both Section 3 of the Clayton Act ${ }^{117}$ and Section 1 of the Sherman Act, ${ }^{118}$ although the elements of these claims are somewhat different: A tying arrangement violates the Clayton act when the seller has a monopoly in the tying product or is restraining a substantial volume of commerce in the tied product, while a tying arrangement violates the Sherman Act only when both these requirements are met. ${ }^{119}$

Whether or not the Clayton Act can be applied to utilities participating in DR markets will depend on the products involved in the tying claims, because the act applies only to the sale or lease of "goods, wares, merchandise, machinery, supplies or other commodities." This means the Clayton Act does not apply to services. ${ }^{120}$ Thus, the most obvious tying claims, those involving a tie-in between the sale and service of DR equipment, will not be covered by the Clayton Act.

Even under Section 1 of the Sherman Act, which is not subject to the Clayton Act's definitional restriction, an arrangement tying sales and service might not be prohibited during the start-up phase where a new technology is being commercialized. In a leading case, the court upheld an arrangement conditioning the sale of a new technology on the purchase of accompanying services, but only during an initial development period for the industry. The court argued that a wave of system failures at the start would have retarded or destroyed the new industry, and that the company's policy of selling its equipment only in conjunction with a service contract was reasonable during the launching of a new business with a highly uncertain future. Once the industry took root and grew, however, the justification for the tie-in disappeared and the arrangement violated Section 1 of the Sherman Act. ${ }^{121}$

115 See Alfred E. KAHN, 2 THE ECONOMICS OF REgUlation 149 (1970) (discussing the "virtue of freedom of entry and competition as a device for innovation.")

116 Hurst (1981) at 516-17; see also SuLLIVAN (1977), at § 150.

117 Section 3 of the Clayton Act states that "it shall be unlawful . . . to fix a price charged . . . on the condition, agreement or understanding that the lessee or purchaser thereof shall not use or deal in the goods, wares, merchandise, machinery, supplies or other commodities of a competitor..." 15 U.S.C. $\$ 14$.

118 Section 1 of the Sherman Act prohibits "contract[s] . . . in restraint of trade." 15 U.S.C. § 1.

119 Times-Picayune Publishing Co. v. United States, 345 U.S. 594, $609-09$ (1953).

120 In one case, a manufacturer of community television antenna systems required that purchasers of its systems to enter into a service contract. The court flatly declined to address the issue under the Clayton Act, stating that Section 3 "does not apply to tie-ins involving services." See United States v. Jerrold Electronics Corp., 187 F. Supp. 545,554 (E.D. Penn. (1960), aff'd per curiam, 365 U.S. 567 (1961).

121 US v. Jerrold Electronics Corp., 187 F. Supp. 545, 557 (E.D. Penn. (1960), aff'd per curiam, 365 U.S. 567 (1961). 
The court's reasoning suggests that a contractual tie between the sale and servicing of DR technologies could be justified where these technologies are in their infancy. and the utility has an interest in ensuring the quality and reliability of its equipment: Of course, opponents could argue as to whether a particular DR technology remains in its infancy, and might try to establish that other qualified providers of the technology exist with as much or more experience as the service providers with whom the utility intends to contract.

The Clayton Act's limitation to 'commodities' also means the law may not apply to the sale of electricity. The courts have decided both ways on this issue. ${ }^{122}$ As stated by one court which concluded that electricity is a commodity under the statute, "electric power can be felt, if not touched. It is produced, sold, stored in small quantities, transmitted, and distributed in discrete quantities." 123 On the other hand, the controversy regarding whether electricity is a commodity has involved the provision of traditional grid-connected service, where the only equipment on the customer's property is the line running from the nearest utility pole, and the customer is purchasing nothing but the electricity itself. By contrast, where utility participation in DR markets involves the sale of integrated electrical equipment, this clearly would be a 'commodity' under the Clayton Act, and it seems likely that sales of DR equipment located on customer premises would fall within the Act because they involve more than just a service.

\subsubsection{Unfair Competition and Unfair Trade Practices under the FTCA}

The Federal Trade Commission Act ("FTCA") is another antitrust statute that may apply to utility participation in competitive markets. Section 5 of the FTCA states broadly that unfair methods of competition and unfair or deceptive acts or practices are illegal. ${ }^{124}$ The Federal Trade Commission ("FTC") has sole authority to enforce this provision, which covers not only conduct that violates the Sherman Act but also conduct which conflicts with the policies of the Sherman Act or the Clayton Act, even though it does not technically violate these statutes. ${ }^{125}$

The FTCA, however, provides for a limited set of enforcement options and remedies. While the Sherman and Clayton Acts allow injured parties to sue for treble damages or injunctive relief, the FTCA only allows enforcement actions brought by the FTC itself. The FTC proceeds by issuing an administrative complaint which is adjudicated in a hearing. The hearing may result in a cease and desist order. The FTC may seek preliminary injunctions to maintain the status quo until the administrative complaint has been adjudicated, and it may seek civil penalties of up to $\$ 10,000$ a day for violations continuing after a cease and desist order is issued. ${ }^{126}$

The FTC clearly has the authority to challenge utility participation in DR markets under the broad scope of Section 5. Enforcement under Section 5 requires proof of unfair or deceptive practices, a lower threshold than monopolization claims under the Sherman Act. Therefore, those opposed to utility participation in DR markets might seek to interest the FTC in the issue, in the hope that the FTC might initiate an enforcement action against a utility participating in competitive markets for DR technologies. In the past, the FTC has expressed an interest in maintaining a competitive market structure for some potential DR markets, including the market for solar energy

\footnotetext{
122 See City of Newark v. Delmarva Power \& Light Co., 467 F. Supp. 763, 773 (D. Del. 1979) (electricity is not a commodity) with City of Kirkwood v. Union Electric Co., 671 F.2d 1173 (8th Cir. 1982), cert. denied 459 U.S. 1170 (1983) and Town of Concord v. Boston Edison Co., 676 F. Supp. 396, 397 (D. Mass. 1988), rev'd on other grounds, 915 F.2d 17 (1st Cir. 1990) (both finding electricity is a commodity).

123 City of Kirkwood v. Union Electric Co., 671 F.2d at 1173, 1181 (1982).

124 15 U.S.C. $\$ 43(\mathrm{a})(1)$.

125 SullivaN (1977), at $\$ 241$.

12615 U.S.C $\$ 45$.
} 
technology. 127 In practice, however, the FTC has tended not to expand the scope of its authority under Section 5 much beyond its authority under the Sherman and Clayton Acts.

\subsubsection{Price Discrimination Under The Robinson-Patman Act}

The Robinson-Patman Act deals with price discrimination, which is the practice of charging different prices to different buyers for essentially the same product. ${ }^{128}$ The Act is relevant to utility participation in DR markets because of the possibility that utilities might discriminate between captive and non-captive customers in the provision of electricity or electricity-related commodities, including DR-related technologies.

The Robinson-Patman Act prohibits discrimination in price "between different purchasers of commodities of like grade and quality .... where the effect .... may be substantially to lessen competition or tend to create a monopoly in any line of commerce."129 Thus, actions under the Robinson-Patman Act require proof of four different jurisdictional elements and two different substantive elements, as follows: (1) There must be an actual sale to two different purchasers. Offers or contracts to sell, leases, and refusals to deal are not subject to the Act. (2) The item sold must be a 'commodity.' The Act does not apply to real property, intangibles, or services. (3) At least one of the sales must cross a state boundary to be considered within interstate commerce and therefore subject to federal law. (4) What is sold must be the same physical goods. (5) The seller must be discriminating based on price. (6) The price discrimination must injure or lessen competition.

As this multitude of elements suggests, the Robinson-Patman Act is easily the most muddled of the federal antitrust statutes. Gellhorn \& Kovacic (1994) call it "a model of statutory obfuscation" and "a troublesome tangle of complex, indeterminate language." 130 Nevertheless, it is worth sorting through its application in the utility context to determine its potential relevance to DR markets.

The requirement that the item sold must be a 'commodity' means the Robinson-Patman Act may not apply to the sale of electricity. ${ }^{131}$ Tangible products such as DR equipment clearly are going to fall within the Act's definition of commodities, but whether less tangible products - such as bundled DR equipment and services - are going to fall within the Act is unclear. In one case, for example, the court expressly held that electricity was a commodity but that electricity transmission service was not a commodity. 132 Where this distinction will be drawn in the future, when utilities and their affiliates are likely to be engaged in a variety of DR markets that blend the use of on-site equipment and interconnection services, remains to be seen.

Robinson-Patman's most obvious application to electric utility DR activities relates to the use of differential rate structures to different classes of customers, including those using DR technologies. The use of differential rates is likely to increase with electric industry restructuring, as utilities face competitive pressures to eliminate cross-subsidies and price their products to reflect their true costs. Although proof that a price differential is cost-justified is a complete defense against a RobinsonPatman price discrimination claim, establishing that cost differentials are justified can pose a significant challenge. For instance, a utility may want to offer electricity to residential customers who have purchased building-integrated photovoltaic systems at a lower price than other residential

127 See, e.g., Federal Trade Commission Bureau of COMPETItion, THE SOlar Market: Proceedings of the SyMPOSIUM ON COMPETITION IN THE SOLAR ENERGY INDUSTRY (1978).

128 GELLHORN \& KOVACIC (1994) at 431.

12915 U.S.C. $\S 13(\mathrm{a})$.

130 GellHORN \& KOVACIC (1994) at 29 \& 434.

131 See earlier Clayton Act discussion. The Robinson-Patman Act was actually an amendment to the Clayton Act, and is subject to the same definitional requirements.

132 City of Gainesville v. Florida Power \& Light, 488 F. Supp. 1258, 1280 (S.D. Fla. 1980). 
customers, on the ground that the photovoltaic systems provides distributed benefits (avoided transmission and distribution costs or avoided transmission losses, for example). The utility could separately compensate the customer for the photovoltaic generation, but the utility finds it simpler to simply offer the reduced price. Such an arrangement could be challenged under the RobinsonPatman Act because the utility is selling the same commodity at different prices. The utility could justify the price differential on the grounds that the customer with the distributed photovoltaic systems is less expensive to serve, but quantifying the distributed benefits may be difficult. 133

Regulatory approval of differential rates is unlikely to exempt them from antitrust scrutiny. In one case, 134 an investor-owned utility was sued by surrounding municipalities to whom it sold wholesale power. The utility argued that the municipalities' Robinson-Patman claim was barred by the FERC's finding that the utility's customer classifications were appropriate. But the court held that the FERC's conclusions did not preclude the price discrimination lawsuit. The court reasoned that just because the FERC may consider arguments based on antitrust concepts did not preclude later antitrust review by the courts, and it emphasized that a court has remedial powers, including injunctive relief and treble damages, that are not available to the FERC. ${ }^{135}$

\subsubsection{STATE ANTITRUST LAWS}

\subsubsection{Comparison And Contrast With Federal Antitrust Laws}

Most state antitrust laws are based on analogous federal statutes. The state laws, in fact, are often referred to informally as 'Baby Sherman Acts' or 'Little FTC Acts.' Typically, these states simply extend antitrust jurisdiction to encompass intra-state conduct that cannot be reached by federal statutes because federal jurisdiction is limited to actions affecting interstate commerce.

State antitrust laws, however, often vary from their federal equivalents in small but significant ways. Therefore, it is inappropriate and unwise to assume that the reach of a 'Baby Sherman Act' is the same as its parent statute. Because the distinctions vary from state to state, no generalization can be made and utilities need to analyze the effect of state antitrust laws on a case-by-case basis.

\section{State Analogues to the Sherman Act}

Many of the target states for this study have statutes that approximate the Sherman Act by prohibiting contracts, combinations or conspiracies to monopolize, attempts to monopolize, or monopolization. These states include California, Florida, Indiana, Kentucky, Ohio, Washington, and Wisconsin. The Sherman Act analogs in Florida, Indiana, Kentucky, Washington, and Wisconsin all parallel the federal statute quite closely. ${ }^{136}$

\footnotetext{
133 In one differential rate case involving an investor-owned utility wholesaling to municipalities at different rates, the utility was compelled to produced evidence justifying its differential rate structure. Although the utility ultimately prevailed, the following passage from City of Batavia v. Commonwealth Edison Co., No. 76 C 4388 , slip op. (N.D. IIl Jan. 16, 1984) suggests that supporting a cost-justification defense can be complicated:

"Commonwealth Edison established that the demand patterns of the individual municipalities were sufficiently similar to allow Edison to make class-by-class comparisons in its cost justification defense. All that is required is a close resemblance of the individual members of each group on the essential point or points which determine the costs considered.' US v. Borden Co., 370 U.S. 460,469 (1962). Here, it was shown that the municipalities had common usage patterns and that the large industrial/commercial customers had common usage patterns; usage patterns were the primary determinant of cost. Edison is not required ..... to make individual comparisons between each City and each large industrial/commercial customer. As was recognized in Borden, 'when a seller deals with a very large number of customers, he cannot be required to establish different cost-reflecting prices for each customer.' " 370 U.S. at 468 .

134 Borough of Ellwood City v. Pennsylvania Power Co., 570 F. Supp. 553 (W.D. Penn. 1983).

135 570 F. Supp at 561-62.

136 See Fla. Stat. Ann. § 542.19; Ind. Code Ann. §§ 24-1-1-1, 24-1-2-1 \& 24-1-2-2; Ky. Rev. Stat. Ann. §367.175; Wash. Rev. Code Ann. $\S \S 19.86 .030$ \& 19.84.040; Wis. Stat. Ann. § 133.03(1) \& § 133.03(2).
} 
California's Cartwright Act ${ }^{137}$ prohibits combinations and conspiracies to monopolize, but it does not prohibit attempts to monopolize or monopolization by a single firm. ${ }^{138}$ In the DR context, this means that a (hypothetical) utility that monopolized the market for fuel cells by acquiring every fuel cell manufacturer in the country and engaging in monopolistic pricing could not be prosecuted under the Cartwright Act, while a utility that conspired with the same fuel cell manufacturers to engage in the same conduct could be prosecuted under the Act.

Ohio's antitrust law is unusually narrow in scope. The law defines 'Trusts' and declares them unlawful. 'Trusts' are defined as combinations for the purpose of (1) creating or carrying out restrictions in trade or commerce; (2) limiting or reducing the production, or increasing or reducing the price of merchandise or a commodity; (3) preventing competition; (4) fixing prices; (5) entering into contracts for sales below cost; or (6) refusing to deal. 139 The law does not prohibit single-firm monopolization or attempted monopolization.

\section{State Analogues to the FTC Act and Robinson-Patman Act}

Some states also have statutes that approximate the Federal Trade Commission Act in prohibiting unfair or deceptive acts or practices, including California and Florida. ${ }^{140}$ Kentucky and Oklahoma also have unfair trade practices statutes, but these laws more closely resemble federal price discrimination laws such as the Robinson-Patman Act.

Kentucky's statute prohibits anyone engaged in the production, manufacture, distribution or sale of the product or service of any public utility to discriminate in pricing between different sections of the state with the intent to destroy competition or to prevent competition, after making allowance for differences (if any) in the grade or quality and in the actual cost of transporting the commodity. ${ }^{141}$ Another section of this statute prohibits sales below cost "for the purposes of injuring competitors and destroying competition."142

Oklahoma's statute prohibits anyone doing business in Oklahoma from engaging in price discrimination between different sections, communities or cities of the state for the purpose of destroying competition, after equalizing for transportation costs. ${ }^{143}$ The statute is similar to Kentucky's except that it does not expressly apply to products or services of a public utility. ${ }^{144}$

These two laws prohibiting price discrimination raise potentially serious issues regarding DR markets. To the extent that the economic viability of DR development depends on the implementation of area- and time-specific costing and/or pricing, a prohibition against differential pricing in different sections of these states might preclude the development of potentially significant DR markets. However, both statutes make allowances for differences in transportation costs, which might be interpreted to include differential costs of electricity transmission and distribution. In addition, the statutes requires that differential pricing be intended to destroy competition, while area-

137 Cal, Bus. \& Prof. Code $\S \S 16720$ et seq.

${ }^{138}$ See Dimidowich v. Bell \& Howell, 803 F.2d 1473, 1478 (9th Cir. 1986); see also, Cowan, 'California's Single-Firm Monopoly Loophole,' 18 Cal. West. L. Rev. 240 (1982).

139 Ohio Rev. Code Ann. § 1331.01(B).

140 See Cal. Bus. \& Prof. Code $\S \S 17000$ et seq.; Fla. Stat. Ann. $\S 501.204$.

141 Ky. Rev. Stat. Ann. § 365.020.

142 Ky. Rev. Stat. Ann. $\$ 365.030(1)$.

143 Okla. Stat. Ann. tit. 79, $\$ 81$.

144 Another section of this statute prohibits a combination or any member of a combination from raising or lowering the price of a commodity handled by a financially weaker competitor in the immediate territory of the financially weaker competitor, when the combination or member at the same time is buying or selling a similar commodity for a different price elsewhere. Okla. Stat. Ann. tit. 79, $\$ 85$. 
and time-specific pricing is arguably pro-competitive rather than anticompetitive. Utilities interested in pursuing DR markets may need to ensure that equalizing for transportation costs or for the quality of goods delivered, as allowed by such statutes, is interpreted to include electricity transmission and distribution costs, and service and power quality improvements available from some types of DR.

\section{Other State Antitrust Statutes}

Oklahoma has a statute prohibiting combinations in restraint of trade, but the statute appears to prohibit price discrimination only. ${ }^{145}$ Washington's Consumer Protection Act contains an explicit prohibition on tying arrangements. ${ }^{146}$

\section{State Antitrust Exemptions}

Some state antitrust laws provide exemptions for anticompetitive conduct by utilities or, more generally, by regulated industries. California, Florida, Kentucky, Texas, Washington, and Wisconsin all provide exemptions for at least some utility-related conduct. However, the nature and scope of these exemptions varies significantly from state to state.

California's Unfair Practices Act exempts any service, article or product for which rates are established by the PUC and which is sold or furnished by any public utility. ${ }^{147}$ This suggests that California utilities interested in DR development have an incentive to submit proposed fees and rates for PUC approval, even for competitive products and services. It may be worth noting that Southern California Edison filed a tariff for its off-grid photovoltaic program, even though it might have obtained the necessary approval for its program without the tariff. ${ }^{148}$

Florida has two exemptions. The one for its 'Baby Sherman Act' covers any activity or conduct exempt under Florida law or exempt from federal antitrust law. ${ }^{149}$ Its 'Little FTC Act' exempts any person or activity regulated by the Florida Public Service Commission. ${ }^{150}$

The exemption in Kentucky's consumer protection statute is the most explicit and unambiguous of all the target states: it says simply that the statute shall not be construed to make illegal the activities of any utility. 151

Washington's Consumer Protection Act exempts certain actions or transactions from state antitrust laws. Among the exempted activities are those permitted, prohibited, or regulated by the Washington Utilities and Transportation Commission or the FERC. ${ }^{152}$ The leading case interpreting

\footnotetext{
145 Okla. Stat. Ann. tit. 79, § 2.

146 Wash. Rev. Code. Ann. $\S 19.86 .050$.

147 The exemption also covers installation and repair services connected with any utility service, article, or product. Cal. Bus. \& Prof. Code $\S 17024$.

148 See Southern California Edison Company, Advice Letter No. 1027-E.

149 Fla. Stat. Ann. $\$ 542.20$.

150 Fla. Stat. Ann. $\$$ 501.212(5). In City of Gainesville v.Florida Power \& Light Co., 488 F. Supp 1258 (S.D. Fla. 1980) a group of municipalities challenged the utility's wholesale pricing as anticompetitve under various federal and state laws. The municipalities argued that this exemption did not apply because the claims arose from the utility's sale of wholesale power, an activity not regulated by the Florida Public Service Commission. The court responded that the exemption refers not just to 'activities' but also to 'persons' regulated by the Commission. Since utilities are corporate 'persons,' the court suggested, they might be broadly exempt from the state antitrust law regardless of the activity in question. The court, however, ultimately refused to decide the issue, referring it instead to the state courts for resolution.

$151 \mathrm{Ky}$. Rev. Stat. Ann. \$367.176(1). 'Utility' means "any person... who owns, controls, or operates or manages any facility used or to be used for or in connection with... [t] he generation, production, transmission, or distribution of electricity to or for the public, for compensation, for lights, heat, power, or other uses." Ky. Rev. Stat. Ann. $\$ 278.010(3)$.

152 Wash. Rev. Code. Ann. $\S 19.86 .170$.
} 
this exemption concluded that it applies only where the Commission is required to regulate entry into the business, rather than just regulating the practices of those who already are in the business. The court also said that even if a business is generally regulated, the specific activity being challenged must be subject to regulation. 153

Wisconsin's 'Baby Sherman Act' includes an explicit exemption for at least some public utility conduct. ${ }^{154}$ The exemption covers public utility activities that are directly required by the public utilities code, or necessary to comply with the public utilities code, as well as activities that are 'actively supervised' by the Public Service Commission. 155

\subsection{TELECOMMUNICATIONS ANALOGUES}

The preceding sections underscore that utility participation in DR activities can raise challenging questions under both federal and state antitrust laws and doctrines condemning anticompetitive behavior. The electric industry is not the first regulated industry to confront these questions as it considers activities beyond its traditional franchised monopoly functions. Airlines, trucking, natural gas, and telecommunications are among the major regulated industries that have already faced similar issues. Of these, telecommunications offers especially revealing lessons for utilities considering whether and how to participate in DR markets. Although there are important differences between telecommunications and electric utilities, it is striking how closely many of the issues addressed over decades of telecommunications deregulation parallel those facing the electric industry now, and especially those surrounding DR activities. This section describes some of these issues and some important principles brought to bear on them in the telecommunications context.

\subsubsection{Lessons From The AT\&T Case \& Its Progeny}

In January of 1984, the American Telephone and Telegraph Company (AT\&T, or the Bell System) entered into a massive antitrust settlement with the US Department of Justice. The settlement was to resolve claims filed ten years earlier by the Department, alleging that AT\&T had illegally monopolized long-distance telephone service, and that its relations with its manufacturing affiliate, Western Electric, violated antitrust laws. Until the 1984 settlement, AT\&T was the largest telecommunications company in the world, with assets exceeding a hundred billion dollars. The settlement divested it of 22 operating companies, to be combined into seven regional telephone companies (the Bell Operating Companies, or BOCs), each behemoths in their own right. The settlement has been described as a near-total victory for the government, so the antitrust theories advanced by the Justice Department are well worth understanding. ${ }^{156}$

The government's case included many elements of interest to utilities considering DR activities. As described by economist Roger Noll, a leading authority on the AT\&T litigation:

153 The court emphasized that the provision exempted 'actions or transactions' rather than an entire 'business or trade,' so the act should apply to a particular unfair or deceptive practice that is not regulated, although the business generally is. Allen v. American Land Research, 95 Wash. 2d 841; 631 P.2d 930 (1981).

154 Wis. Stat. Ann. $\S 133.07(2)$.

155 The 'active supervision' clause, added by a 1993 amendment, appears to expand the exemption. Previously, utility activity approved by the Commission but not expressly required by the code might not have been exempt. With this clause added, such activity is likely to be exempt. However, we have found no cases applying or interpreting this clause.

${ }^{156}$ Much of the following discussion draws on a case study by Roger G. Noll and Bruce M. Owen, The Anticompetitive Uses of Regulation: United States v. AT\&T, published in The Antitrust Revolution (J. Kwoka and L. White, Eds.; Scott Foresman, 1989). This study, written by experts instrumental in developing the government's successful case against AT\&T, is highly recommended reading for those interested in antitrust and competitive issues affecting utility DR roles. 
[t] he essence of the government's case against the Bell System was that it had used its status as a regulated monopoly in most of its markets to erect anticompetitive barriers to entry in potentially competitive markets. The novel feature of this line of argument was that much of the Bell System's anticompetitive behavior was economically rewarding to the company only because it was regulated and, consequently, that one area of public policy, economic regulation, was a cause of illegal acts in another area, antitrust.

... [M]ost of the government's case hinged on its view of regulation, [which was] that regulators did constrain the behavior of the Bell System, but not perfectly . As a result, the Bell companies had an important degree of flexibility in setting prices and deciding which services to provide, and they succeeded in earning profits that, while substantially below the monopoly returns that might be earned in an unregulated market, were nonetheless greater than a firm in a competitive industry could expect. ${ }^{157}$

The government leveled four types of charges against AT\&T, all potentially relevant here.

Refusals to Deal. First, it argued that AT\&T had unlawfully refused to deal with its potential competitors. As to long distance services, it had initially refused to permit private systems and competing long distance carriers to connect with its network, and later allowed them to connect only with costly devices that were technically inferior to those it made available to its own Bell System companies. As to equipment, Bell refused to buy products made by its competitors, or to allow its customers to buy them or connect them to its system, claiming that equipment from manufacturers other than its own Western Electric subsidiary threatened system integrity and employee safety.

Discriminatory Practices. The government's second charge was that AT\&T engaged in discriminatory practices designed to preserve its long distance and customer equipment monopolies by raising its competitors' costs. These practices included requiring expensive and unnecessary protective devices for equipment manufactured by others, and providing unequal access for competing long distance carriers through inferior but expensive "line-side" connections.

Regulatory Abuse and "Pricing Without Regard to Cost". The two other charges made by the Justice Department are particularly interesting in the DR context. One was that AT\&T had abused the regulatory process by failing to provide regulators with cost information adequate to determine whether prices charged in competitive markets were reasonable. The other was that it had engaged in an exclusionary and illegal form of pricing referred to as "pricing without regard to cost."

The cost information the government charged was inadequate consisted of

estimates ... based on hypothetical configurations of components of the long-distance network, with average prices of inputs, rather than the actual design of real components of the network and the prices actually paid. The estimates were also "bottom up" engineering cost estimates, rather than estimates derived from actual experience in constructing and operating the network. The result was cost estimates that were only loosely related to the costs of providing service ... As a result Bell companies never could answer questions such as "What is the cost of providing local telephone service to households in Cambridge, Massachusetts?" or "What is the cost of a peakperiod long-distance telephone call from Cambridge, Massachusetts to Palo Alto, California?" Instead, Bell could only provide hypothetical answers from engineering cost analysis, or average book costs for broad categories of services over large geographic areas. ${ }^{\text {iss }}$

From this the government argued not that Bell "willfully withheld information that its own management possessed, but that it designed an accounting system that obscured the actual sources of costs ... and that such a policy could serve no other purpose than the anticompetitive [one of making] the regulator's job of preventing anticompetitive pricing next to impossible." 159 In other

\footnotetext{
${ }^{157}$ Id., p. 295; emphasis added.

${ }^{158}$ Id., p. 308; emphasis added.

${ }^{159}$ Id.
} 
words, the government successfully characterized Bell's practice of relying on engineering estimates of system average costs without any real data on the cost to provide particular services to particular groups of customers, as an illegal strategy to thwart effective price regulation.

Closely related to this argument was the government's claim of "pricing without regard to cost". To establish predatory pricing under the antitrust laws normally requires a showing that the defendant temporarily reduced prices below its costs in order to drive out competitors, with the purpose of increasing prices later to reap monopoly profits once the competition is eliminated. The government would have had difficulty making these showings in the AT\&T case, so it advanced a different theory: that, unsupported by reasonable cost data, AT\&T's pricing in fact reflected nothing more nor less than what it would take to exclude competitors from its markets and maintain its monopoly. As Professor Noll writes:

Such pricing behavior clearly would be irrational for an ordinary, unregulated firm. But the Bell System could readily have assumed that losses in these [competitive] services, even from prices that were a small fraction of cost, would be negligible compared to the Bell System's total revenues and so could readily be made up by increasing regulated monopoly prices by a very small amount. Thus, pricing without regard to cost was not irrational for the Bell System as long as regulators held its prices and overall return below the level that it would achieve as an unconstrained monopolist. ...

The implication of this allegation for regulated monopolies is profound. It implicitly confers on regulated firms a positive antitrust obligation to know their costs and to be sure that their prices are not anticompetitive, even if the regulators approve their price structure and do not care whether prices are anticompetitive. ${ }^{160}$

Relevance to DR Activities. Each of the four Justice Department theories outlined above could be relevant to utility participation in DR markets. Utilities that control access to transmission and/or distribution systems and also seek to develop DR on their systems theoretically could refuse connections or provide inferior ones to prospective DR competitors. They could raise unreasonable concerns about system integration or safety, or impose unnecessary and discriminatory costs on other DR providers. ${ }^{161}$ Utilities competing in DR markets and providing regulators only with average cost data (rather than area- and time-specific data) might be accused of failing to provide information from which regulators could determine the reasonableness of prices charged in DR markets. And, as in the AT\&T case, utilities subject to that claim might also be vulnerable to arguments that the absence of detailed cost information suggests that the utility is "pricing without regard to cost", to take advantage of opportunities for anticompetitive cross-subsidies. This is not to suggest that these claims could be proved or would necessarily prevail, but only that the AT\&T liability theories could be advanced in the DR context.

Separation of Competitive and Regulated Operations. The government's claims led to the settlement of the AT\&T litigation in January 1984. The basic settlement terms were as follows:

The "bottleneck theory" dictated a separation of the bottleneck monopoly from all competitive services, including transmission services, information services, and equipment supply. Inasmuch as local exchange service was regarded as a "natural" monopoly ... while long distance service was now regarded as competitive, it followed that the twenty-two Bell Operating Companies (BOCs) should be severed from AT\&T long lines and made independent. By the logic of the bottleneck theory it also followed that the BOCs should not be authorized to enter those markets considered competitive lest as independent bottleneck monopolies they revive AT\&T's anticompetitive strategies. ... The BOCs were reorganized as subsidiaries of seven new regional

\footnotetext{
${ }^{160} \mathrm{Id}$, pp. 310, 312. It is interesting to speculate whether this "positive antitrust obligation" might be held to require the type of area- and time-specific costing discussed in Chapter 3, even if utility regulators do not require it, and even if utilities do not regard it as information essential to survival in a competitive environment.

${ }^{161}$ Effective implementation of the FERC's proposed open access and comparability requirements arguably would relegate these concerns to local distribution situations beyond the FERC's jurisdiction.
} 
holding companies [and] prohibited from providing information [or "enhanced"] services ... and from manufactiring CPE [customer premises equipment], though they were allowed to supply CPE made by others. ${ }^{162}$

In preparation for the AT\&T divestiture, the Federal Communications Commission (FCC) had conducted a proceeding to determine whether to require the BOCs to insulate their competitive offerings from their monopoly services through the use of separate subsidiaries rather than through accounting separation alone. ${ }^{163}$ This proceeding resulted in the $B O C$ Separation Order ${ }^{164}$. There the FCC concluded that the BOCs' monopoly power over local exchange bottlenecks gave them the incentive and ability to cross-subsidize competitive services through monopoly rates, and to hobble competitors with inferior network access. The FCC found that non-structural regulations on cost accounting and network practices alone could not preclude anticompetitive practices by the BOCs. It therefore ordered that competitive services (i.e., "enhanced" services and CPE) be provided through legally separate subsidiaries, or possibly unincorporated divisions.

Again, the approach and issues described in the FCC's decision are instructive for those considering DR activities. The FCC invoked four criteria to assess whether a telecommunications carrier should be required to offer competitive services through a separate business entity rather than simply maintaining separate accounting:

(a) a carrier's ability to engage in anticompetitive activity through control over "bottleneck" facilities, i.e., local exchange and toll transmission facilities ...; (b) a carrier's ability to engage in cross-subsidization to the detriment of the ... ratepayer; (c) the integrated nature of the carrier and affiliated entities, with special emphasis on research and development and manufacturing capabilities that are used in conjunction with, or are supported by, [monopoly] revenues; and (d) the carrier's possession of sufficient resources to enter the competitive market through a separate subsidiary. ${ }^{165}$

The FCC's approach in the BOC Separation Order was to balance the benefits and costs of structural separation. The benefits of structural separation were said to include:

- protecting monopoly ratepayers from costs transferred from unregulated (CPE) activities;

- protecting the general public against anticompetitive activities such as predatory pricing of competitive services and denial of network access; and

- reducing joint and common costs (e.g., for $R \& D$, marketing, maintenance, and billing) between regulated and competitive activities, and making cost-shifting easier to detect. ${ }^{165}$

The costs of structural separation urged by the BOCs, but largely discounted by the FCC in this proceeding, included:

- the costs to establish, staff and operate independent entities; and

- the inability to operate efficiently in competitive markets due to diseconomies of scale from separate operations.

\footnotetext{
${ }^{162}$ Glen O. Robinson, The Titanic Remembered: AT\&T and the Changing World of Telecommunications, 5 Yale Journal On Regulation 517 (1988), at pp. 31-32.

${ }^{163}$ These issues had been addressed for AT\&T in FCC proceedings known as the First Computer Inquiry ("Computer I"; 28 F.C.C. 2d 291, 1970) and the Second Computer Inquiry ("Computer II"; 77 F.C.C. 2d 384, 1980). For concise descriptions of these proceedings, see Robinson, supra note 6, and People of State of California et al. vs. F.C.C., 905 F.2d 1217 (9th Cir. 1990).

${ }^{164}$ Report and Order, In re: Policy and Rules concerning the Furnishing of Customer Premises Equipment, Enhanced Services, and Cellular Communications Services by the Bell Operating Companies, 95 F.C.C. 2d 1117 (1983).

165 Id., quoted at p. 1128.

${ }^{166}$ Id.; see pp. 1129-1137.
} 
In the 1983 Separation Order, the FCC found that the benefits of structural separation outweighed its costs, and required the BOCs to implement it. ${ }^{167}$ Just fourteen months later in the Third Computer Inquiry ${ }^{168}$ the FCC reversed itself and decided to relieve the BOCs of this requirement based on its perception of changes in the industry since the 1984 divestiture. Although the US Court of Appeal later held the FCC's about-face unsupported by the record and overturned it, the FCC's rationale and the court's response remain of interest in the DR context.

Over the years the FCC had found that the protections of structural separation are not without cost. In the BOCs' case the Commission found and the court accepted that

... separation has discouraged innovation in developing and marketing new enhanced services technologies, has prevented the BOCs from providing customers with efficient packages of basic and enhanced services, and has generally created inefficiencies by forcing the BOCs to maintain duplicate organizations and facilities. [They] have had to raise the price of certain services, withhold others from the market, and perhaps never develop others because of the inefficiencies of structural separation.

[The integration of regulated and unregulated services, on the other hand] would yield some economies of scale. On the technological side, the BOCs could integrate enhanced services equipment more closely into the telephone network. On the marketing side, the BOCs could offer customers ... packages of basic and enhanced services [that would] minimize transaction costs, and reduce delays and coordination problems in satisfying consumer demands. Moreover, the BOCs would not have to maintain, and customers would not have to pay for, separate organizations and facilities for operating and repairing basic and enhanced services. ${ }^{169}$

In the Third Computer Inquiry the FCC also found that. changed circumstances in the industry had diminished the relative benefits of separation identified in its earlier order. Specifically, it found that the emergence of strong competitors and new requirements that monopoly carriers provide comparable network access, notification of network changes, and customer usage information similar to policies adopted or proposed in recent FERC proceedings - had made it possible to protect ratepayers and competitors through less obtrusive accounting safeguards. ${ }^{170}$ The Court of Appeal was not persuaded that these changes adequately supported the FCC's policy reversal as a matter of administrative law, but its analysis remains useful in evaluating utility structural options in emerging DR markets.

\subsubsection{State "Regulated Competition" Statutes}

Beginning in the mid-1980's and accelerating in the last few years, a number of states have adopted statutes establishing or authorizing new regulatory regimes for telecommunications. These. laws do not apply directly to electric utilities, but they may indicate directions that states are likely to take in regulating electric industry activities that include arguably competitive $D R$ elements. At least one state, Indiana, has already used its telecommunications statute as a template for similar legislation establishing alternative regulation for energy utilities, ${ }^{171}$ and others appear to have adapted parts of other telecommunications statutes for similar purposes. ${ }^{172}$

In general, these statutes acknowledge and promote the benefits of competition. They permit telecommunications utilities to enter markets for competitive services, while prohibiting

167 With some exceptions for joint billing, installation and maintenance, referrals, and administrative services.

${ }^{168}$ Notice of Proposed Rulemaking, Amendment of $\$ 64.702$ of the Commission's Rules and Regulations, Docket No. 85229, 50 Fed. Reg. 33,581 (August 1985).

${ }^{169}$ People of State of California et al. vs. F.C.C., 905 F.2d 1217 (9th Cir. 1990), at p. 1230.

${ }^{170}$ See Id., pp. 1229 et seq.

${ }^{171}$ See Ind. Code Ann. §8-1-2.5, Alternative Utility Regulation (1995).

${ }^{172}$ See, e.g., Tex. Rev. Civ. Stat., art 1446c-0, \$2.001. 
anticompetitive behavior such as cross-subsidization and denial of network access. Most of them direct utility commissions to determine which telecommunications services are competitive and which are not, and to adopt alternative forms of regulation befitting each. These alternative forms include non-cost-based, non-rate-of-return regulation based on indices, price caps, rate ranges, zoned rates, revenue sharing plans, competitors' prices, and other non-traditional approaches. ${ }^{173}$ The statutes establish continuing jurisdiction in the commissions, and permit them to reimpose traditional regulation if the public interest requires that.

Florida, Indiana, Kentucky, Ohio, Oklahoma, and Texas are among the states that have established new regulatory regimes for telecommunications. The stated legislative findings and policies behind these enactments include some or all of the following (many of which are echoed in recent electric industry restructuring discussions):

- state goals include affordable, reliable, high quality, universal telephone service;

- technical advances and regulatory changes have increased telecommunications competition;

- competition is desirable to ensure diverse providers and services and consumer choice;

- traditional regulation was not designed and is not suited for a competitive environment;

- flexible regulation is necessary to promote consumer choice and reduce regulatory burdens, while still protecting monopoly ratepayers;

- alternative forms of regulation are needed to match different degrees of market competition.

Some of these "regulated competition" statutes are straightforward, leaving wide discretion to state utility commissions. Indiana's, for example, provides simply that the commission may decline jurisdiction, in whole or in part, over telephone companies or services where the public interest requires. In determining the public interest, the commission is to consider whether exercising its jurisdiction would be unnecessary or wasteful; would produce tangible benefits to customers; and would inhibit a regulated entity from competing with unregulated service providers. The commission is authorized to adopt rules and orders that promote cost minimization, better evaluation of utility conditions and needs, less costly regulation, increased efficiency, or "regulation consistent with a competitive environment". ${ }^{174}$

Oklahoma's 1995 statute is equally spare, directing its commission to examine alternatives to existing telecommunications regulation and adopt flexible policies that "recognize the competitive characteristics of different telecommunications providers and their services and market areas." The commission may implement alternative forms of regulation for a three-year trial period and report the results to the legislature and the governor. It may adopt plans that benefit consumers through infrastructure or technology investment and that share revenues with them in such forms as refunds, rate reductions, or enhanced services. The commission may also adopt policies to preserve universal service, and to protect against predatory or discriminatory pricing, cross-subsidies, and other anticompetitive abuses, and may require local exchange providers to facilitate efficient interconnections. ${ }^{175}$

Kentucky's 1992 legislation embodies elements of both statutes just described, but contains a more complete listing of "public interest" criteria that determine whether alternative regulation is appropriate. These include:

\footnotetext{
${ }^{173}$ See Chapter 3, Sections 3.2 et seq. for a discussion of some of these options in the electric utility context.

174 See Ind. Code Ann. §§8-1-2.6-1 et seq.

175 See 17 Okl. St. $\$ 137.1$ (1995).
} 
- the extent to which competing services are available in the relevant market, and the ability and willingness of competitive providers to make them available;

- the number and size of competitive service providers;

- the impact of the proposed regulatory changes on universal service, and the availability and price of existing services;

- the existence of safeguards to prevent cross subsidization of competitive services; and

- whether regulation inhibits a regulated utility from competing with unregulated providers.

The Kentucky statute expressly prohibits cross-subsidies, requires separate accounting (but not structural separation) for monopoly and competitive activities, and establishes a procedure to compel interconnections. ${ }^{176}$

The Florida and Texas statutes are far more complex than those just summarized (occupying 25 and 75 pages of their state codes, respectively). Basically, however, Florida legislates much of what some other states leave to commission discretion. It distinguishes between established local exchange companies and "alternative" - i.e., new - ones, and imposes less regulation on the latter during the transition to competitive markets. The law also distinguishes between "basic" and "nonbasic" services. It permits large existing service providers to elect price regulation instead of traditional rate-of-return regulation. For "basic" services, price regulation includes price caps, a requirement to offer a flat rate option, and a prohibition on measured service. For "nonbasic" services, companies electing price regulation are required to file tariffs, but may increase rates on short notice, and may meet competitors' offerings by de-averaging rates, offering discounts, packaging services, and executing individual service contracts. Under Florida's scheme, companies electing price regulation are exempt not only from rate-of-return regulation, but from the obligation to serve and at least some filing and inspection requirements. However, the commission retains oversight jurisdiction over nonbasic services to resolve complaints and prevent cross-subsidies. ${ }^{17}$

Florida, like many other states, makes service to persons in poor, rural, and high-cost areas i.e., "universal service" - an important goal of its telecommunications policy. Its statute directs that universal service objectives are to be maintained after local exchange markets are opened to competition. Universal service usually implies rates based on system averages rather than the actual costs of serving high-cost areas. Since system average rates may be incompatible with competitive pricing, the Florida statute directs the commission to consider whether to require de-averaging of basic local rates, and whether targeted subsidies are a more appropriate way to meet universal service objectives. ${ }^{178}$ Although universal service appears to be a somewhat lower policy priority in the electric arena, the targeted subsidy approach might be a way to reconcile it with area- and timespecific pricing to create an environment more conducive to DR development.

The telecommunications portion of the new Texas Public Utility Regulatory Act of 1995 (PURA), contains stronger rate averaging provisions - noteworthy here because they are echoed to some extent in the title governing electric utilities. PURA confers exclusive commission jurisdiction over telecommunications utilities, but limits this jurisdiction as to utilities which are not "dominant carriers". Among other things, this limited jurisdiction includes authority "to require the maintenance of statewide average rates or prices". ${ }^{179}$ The Act goes on to authorize the commission to determine the level of competition in specific markets and establish alternative regulation for competitive activities, while prohibiting rates that are unreasonably preferential or discriminatory, predatory, or

\footnotetext{
${ }^{176}$ See Ky. Rev. Stats $\S \S 278.512$ et seq.; see also Ohio Rev. Code Ann. $\$ 4927.03$, listing similar factors for the commission to consider in determining whether regulatory exemptions are warranted by the existence of competition.

${ }^{177}$ See Fla. Stat. Ann. $\$ \$ 364.01$ et seq.

${ }^{178}$ Id., $\$ 364.025$.

${ }^{179}$ Tex. Rev. Civ. Stat., art. 1446c-0, $\$ 3.051(c)(4)$. 
anticompetitive - and to "enter such orders as may be necessary to protect the public interest" where a utility fails to maintain statewide average rates (apparently including reimposing its full regulatory authority). ${ }^{180}$ Title II of the Act governing electric utilities does not go so far, but does prohibit "unreasonable" rate differences among localities or service classes and, without commission approval, rates outside municipal boundaries that exceed $115 \%$ of average municipal rates in the county. ${ }^{181}$

As noted earlier, these telecommunications statutes do not apply directly to electric utilities, but may be harbingers of changes to come. In Indiana, those changes have already arrived in the form of a new "Alternative Utility Regulation" chapter added to state law in 1995. That chapter adapts much of the language of the state's telecommunications statute (summarized above) 'to electric utilities, and creates a similar regulatory regime. As the state's goal, it substitutes for universal telecommunications service "the provision of safe, adequate, efficient, and economical retail energy services", followed by the same recitations concerning increasing competition, the inadequacy of traditional regulation to deal with it, and the need for regulatory flexibility. ${ }^{182}$

Like Indiana's telecommunications statute, its energy utility statute authorizes the commission to decline to exercise some or all of its jurisdiction at a utility's request (but conditioned on the utility's voluntary election of alternative regulation), where the commission determines that:

- exercising jurisdiction would be unnecessary or wasteful or would inhibit the utility from competing with unregulated providers, and/or

- declining jurisdiction would benefit the utility, its customers, or the state, or promote utility efficiency. ${ }^{183}$

For companies that elect to proceed under the statute, the commission may adopt alternative regulatory mechanisms that "enhance or maintain the value of the energy utility's retail energy services or property", and may use market rates, price caps, indexed prices, and other performancebased approaches designed to promote efficiency. ${ }^{184}$ The commission may reassert full regulatory jurisdiction if the public interest requires, but only under limited circumstances if it has declined jurisdiction or approved a utility plan for alternative regulation for a fixed term of years. ${ }^{185}$

The Indiana statute, or others like it that might evolve from state telecommunications legislation, suggest possible models for alternative regulation of utilities involved in DR activities.

\subsubsection{CONCLUSIONS}

Antitrust and anticompetitive considerations will play a major role in shaping utility participation in DR activities. Federal antitrust laws, and many state laws patterned after them, apply to utilities as they do to other commercial entities. Historical doctrines immunizing regulated utilities from antitrust exposure offer protection only where the challenged activities are undertaken pursuant

\footnotetext{
${ }^{180} \mathrm{Id} ., \S 3.051(\mathrm{e}),(\mathrm{g}),(\mathrm{m})$.

${ }^{181}$ Id., $\$ 2.213, .214$.

${ }^{182}$ See Ind. Code Ann. §8-1-2.5-1. Compare 1995 Texas Public Utility Regulatory Act, Tex. Rev. Civ. Stat., art. §1446c-0, \$2.001(a): "The legislature finds that the wholesale electric industry ... is becoming a more competitive industry which does not lend itself to traditional electric utility regulatory rules, policies, and principles and that ... the public interest requires new rules, policies, and principles be formulated and applied to protect the public interest in a more competitive marketplace. The development of a competitive wholesale marketplace that allows for increased participation by both utilities and certain nonutilities is in the public interest." Among many other significant changes, the Act goes on to authorize wholesale and at least some retail electricity charges that are below approved tariffs but at or above utility marginal costs (see $\$ \S 2.001(\mathrm{~b}), 2.052(\mathrm{~b})$ ).

${ }^{183}$ Id., §8-1-2.5-5.

184 Id., §8-1-2.5-6.

185 Id., §8-1-2.5-7.
} 
to state legislative or regulatory policy that is clearly articulated and affirmatively expressed, and are subject to active supervision by state regulators. Immunity is unlikely where utilities voluntarily initiate activities in markets that are or can be essentially competitive.

In these situations, courts and regulators have invoked federal and state antitrust law and anticompetitive principles to guard against two principal concerns. One is to protect utility ratepayers against the use of monopoly assets to cross-subsidize the utility's competitive activities at ratepayer expense. The other is to protect competitive markets against the unfair effects of such abuses. Both concerns can give rise to antitrust claims, usually under the federal Sherman Antitrust Act, but also under other federal and state laws designed to preserve competition.

Conventional Sherman Act claims of monopolization and attempted monopolization may be hard for challengers to establish during the early stages of any utility DR implementation. However, the theory of monopoly leveraging, where courts have accepted it, requires a lower standard of proof, increases potential exposure to claims, and creates additional uncertainty over the permissible extent of utility participation in competitive markets. Even where leveraging has been rejected as a basis for Sherman Act liability, its underlying principles may be invoked in regulatory proceedings to constrain utility DR activities.

Telecommunications litigation suggests that courts and regulators will respond to the use of monopoly power in a utility's core markets to erect barriers in competitive markets, by requiring strict separation of monopoly from competitive activities. At a minimum they have required separate accounting. In some cases they have required structural separation into legally distinct corporate entities operating independently and at arms' length from each other. Whether and under what conditions such requirements might be applied to energy utilities engaging in DR activities are open questions at this point, but they deserve serious consideration when developing business strategies for DR implementation. Recent state telecommunications statutes that permit alternate forms of regulation and limited utility entry into competitive markets subject to safeguards may prove to be forerunners of similar developments for energy utilities (as they already have in Indiana). 
Previous sections have identified various legal and regulatory doctrines aimed at protecting ratepayers, consumers, and competitors against abuses of the utility's monopoly position. These doctrines suggest that if particular DR activities can be characterized as competitive, they may need to be undertaken outside the regulated utility. Utility management may also believe that some DR activities entail different and higher risks than conventional utility activities, and may seek to pursue them as unregulated, nonutility operations that can yield higher rewards for success.

This chapter begins by examining traditional state public utility laws that could dictate results quite at odds with doctrines favoring separation from the regulated utility, and could actually result in commission regulation of entities pursuing DR activities that are arguably competitive. These laws are especially relevant to DR facilities located on customer sites, and those furnishing energy offsite to someone other than the facility owner. Despite widespread pursuit of competition and industry restructuring among state regulatory commissions, these laws remain in force in most states and will continue to govern until legislatures replace them with new regulatory regimes.'

In addition to defining what kinds of entities and activities are and are not subject to regulation, existing state public utility laws address siting of energy facilities, and certification of facilities, services, territories, and/or environmental compliance. These topics are also potentially relevant to DR development, and are reviewed briefly following the discussion of state public utility regulation and exemptions.

\subsection{STATE PUBLIC UTILITY REGULATION AND EXEMPTIONS}

\subsubsection{Basic Structure Of State Public Utility Laws}

The basic structure of traditional state public utility laws is quite similar from state to state. However, specific state provisions differ in ways that can significantly affect DR planning. The examples presented here illustrate typical state approaches and the kinds of issues they raise. They are quite representative of state laws in this area, but this summary is no substitute for a thorough analysis of particular laws and regulations governing specific situations (especially as utilities and their affiliates expand their activities beyond geographic areas they have traditionally served).

\section{Covered Commodities and Activities}

Almost all states have statutes defining "public utilities" or "public service companies" subject to state utility commission jurisdiction. These definitions typically specify the types of commodities (electricity, gas, heat, water, etc.); the types of activities (production, generation, transmission, distribution, delivery, sale, etc.); and/or the types of entities (electric corporations, gas corporations, etc.) to which public utility status may attach.

\footnotetext{
1 As part of its ongoing restructuring proceedings, the California Public Utilities Commission asked interested parties to submit briefs on state (and federal) laws that would be impacted by its restructuring proposals. In their January 31,1995 briefs, Pacific Gas \& Electric cited dozens of key state public utility code sections that would need to be repealed or drastically altered, and Southern California Edison suggested that "the Legislature would have to re-write the Public Utilities Code completely, not to mention portions of [other codes]" to accommodate direct access and retail wheeling proposals. (SCE brief in Dockets R.94-01-031 and 1.94-04-032, at p. 8). These views, echoed by other participants, 72 suggest how fundamentally the kinds of existing laws reviewed here will change as states pursue industry restructuring.
} 


\section{"Public Use" Requirement}

Supplying one of the specified commodities or engaging in one of the specified activities will not necessarily subject the supplier to regulation as a public utility. Most state definitions and many court decisions additionally require that the commodity or service be offered "to the public" or "for public use" (or in the words of some statutes, "for hire" or "for compensation"). These terms reflect traditional legal doctrines to the effect that states generally cannot impose utility regulation upon essentially private services, not offered to the public at large or to some substantial portion of it.

The question of what constitutes "public" as distinguished from "private" service rarely arises for conventional centralized utilities, whose service to thousands or millions of customers over wide geographic areas is so clearly "public" that it requires no analysis. However, the question can be critical for DR providers considering distributing some or all of their electric (and/or cogenerated heat) output to more limited groups of retail customers (such as shopping center or industrial park occupants, residential apartments or condominiums, etc.) under novel service arrangements. As appears below, the statutes themselves usually provide little or no guidance on this question. It is largely an area of court-made law interpreting general statutory directives, and interpretations vary from state to state.

\section{State Exemptions}

Where a covered commodity or activity is supplied "to the public" or performed "for public use" the supplier will be subject to regulation as a public utility, unless some other provision of law exempts it. Most state statutes provide explicit exemptions for specified suppliers or end uses. These provisions exempt, among others, publicly-owned entities, nonprofit corporations and membership cooperatives, certain small-scale systems, and uses by the producer and its tenants solely on private property. Many states also exempt alternative energy producers and distributors employing cogeneration, renewables, or other preferred resources, and some now exempt power marketers and wholesale generators defined by EPAct.

\section{PURPA Exemptions}

Since 1978, state utility definitions and exemptions have been subject to overriding federal provisions contained in the Public Utility Regulatory Policies Act ("PURPA"). ${ }^{2}$ PURPA recognized that the prospect of comprehensive federal and state utility regulation had historically discouraged alternative energy activities, so it directed the FERC to make rules exempting qualifying facilities $(\text { "QFs") })^{3}$ from the most burdensome provisions of these laws, including state utility laws governing the rates, finances and organization of electric utilities. ${ }^{4}$

DR facilities using renewables or cogeneration may meet PURPA's QF criteria, and thus benefit from these exemptions. However, they apply only to wholesale electric sales by QFs to electric utilities, not to retail electric sales or to heat sales, activities over which the FERC has no jurisdiction. These activities continue to be governed by state law utility definitions and exemptions described generally above, and examined in more detail below.

2 Pub. L. 95-617, 92 Stat. 3117 (November 9, 1978).

3 QFs include "small power production facilities" (SPPFs) and "cogeneration facilities" (CGFs). A SPPF is a facility of up to $80 \mathrm{MW}$ (except as to certain waste-fueled facilities), which produces electric energy solely by the use of any combination of biomass, waste, renewable resources, or geothermal resources as its primary energy source. A CGF is a facility which produces electric energy and steam or other forms of useful energy (such as heat) used for industrial, commercial, heating, or cooling purposes. To be "qualifying" facilities, SPPFs must meet fuel use standards and CGFs must meet operating and efficiency standards prescribed by FERC, and both must be owned not more than $50 \%$ by an electric utility or certain affiliated entities. See 16 U.S.C. $\$ \S 796(17)(A)-(D),(18)(A)-(C)$, and 18 C.F.R. $\$ \S 292.203-.206$.

4 See PURPA $\S 210($ e) [16 U.S.C. $\$ \S 824 a-3(e)]$ and 18 CFR $\S \$ 292.601-602$. As of early 1996, Congress was considering various proposals to amend or repeal PURPA, but so far these seem to have focused more on its power purchase requirements than on its regulatory exemptions. 


\subsubsection{State Public Utility Laws Applied To Ownership \& Operation Of Distributed Resources}

Few laws specific to "distributed resources" per se exist at this point, although there is considerable law relating to some of the resources and service configurations under consideration for DR applications. The following discussion reviews some of these laws and suggests the kinds of issues likely to arise as DR installations become more widespread.

\section{Covered Commodities \& Services}

Among the various commodities and services covered by state "public utility" definitions, the ones most relevant to DR activities are those which arguably include DR outputs that might be exported from the facility - primarily electricity, but also steam, heat, or water in the case of cogeneration facilities. Electricity definitions are generally straightforward, and have not required or received much interpretation. Many statutes also cover steam, heat and/or water in some form. For these commodities and services, variations in statutory language and court -or commission interpretations can have important implications for DR regulatory treatment.

The following excerpts from the New York, Ohio and Texas statutes are fairly typical of the range of state utility "commodity/service" definitions. They illustrate the kind of language used in most state statutes, and certain variations of interest in the DR context:

\section{NEW YORK:}

The term "electric plant" ... includes all real estate, fixtures and personal property operated, owned, used or to be used for or in connection with or to facilitate the generation, transmission, distribution, sale or furnishing of electricity for light, heat or power ...

The term "steam plant" ... includes all real estate, fixtures and personal property operated, owned, used or to be used for or in connection with or to facilitate the generation, transmission, distribution, sale or furnishing of steam for heat or power.

The term "water system" ... includes all real estate, attachments, fixtures ... water plant ... and all property either real, personal or mixed, owned, operated, used or to be used for or in connection with or to facilitate the distribution, sale or furnishing of water for domestic, commercial or public uses ...

\section{OHIO:}

Any person, firm ... or corporation ... is:

... An electric light company, when engaged in the business of supplying electricity for light, heat, or power purposes to consumers within this state; ...

... A water-works company, when engaged in the business of supplying water through pipes or tubing, or in a similar manner, to consumers within this state; ...

... A heating or cooling company, when engaged in the business of supplying water, steam, or air through pipes or tubing to consumers within this state for heating or cooling purposes; ...

TEXAS:

"Public utility" or "utility"... means any person, corporation ... cooperative corporation ... other than a municipal corporation ... owning or operating for compensation in this state equipment or facilities for producing, generating, transmitting, distributing, selling, or furnishing electricity ...

\footnotetext{
5 N.Y. Pub. Serv. Law $\$ \$ 2(12), 2(21), 2(26)$; emphasis added.

6 Ohio Rev. Code $\$ 4905.03$ (4), (8), (9); emphasis added.

${ }^{7}$ Tex. Rev. Civ. Stat. Ann., Art. 1446c-0, §2.0011(1) (1995).
} 


\section{Electricity}

Like these three states, virtually all others include electricity as a regulated commodity. As noted above, its definition has not been controversial. The questions that arise over the regulation of electricity sales generally focus on other issues, such as the scope of service and available exemptions (see "public use" and state exemptions discussions, below).

\section{Steam, Heat and Water}

The application of statutes covering "steam," "heat," and "water" can be important to DR facilities employing cogeneration and considering offsite thermal distribution, and these have has been more controversial. The statutes themselves rarely define these commodities beyond the basic language set forth above, so it is left to commissions and courts to interpret their meaning. The following New York and Texas commission decisions illustrate the kinds of issues that arise in this context.

In a 1983 case $^{8}$ the New York Public Service Commission was asked to decide whether a $\$ 15$ to $\$ 20$ million cogeneration district heating system proposed to be built in the City of Rochester would be considered a "steam plant" under the definition quoted above, and whether its owner/operator would therefore be regulated as a "steam corporation" under New York's Public Service Law.' The proposed system was to distribute $250^{\circ}$ to $394^{\circ} \mathrm{F}$ hot water through insulated underground pipes to customers. The water was to be kept under pressure to prevent boiling. Each customer would extract heat from the system through a heat exchanger located at its site, and would meter the heat extracted.

The Commission ruled that the proposed system would not be a "steam plant" and its owner/operators would not be regulated as a "steam corporation." The decision apparently was based on a commission staff analysis interpreting the word "steam" according to its literal dictionary definition as "water in the state of vapor": since the high pressure in the proposed system would prevent the hot water from vaporizing, it would be a "hot water" system, not a "steam" system. ${ }^{10}$ This ruling is interesting because it illustrates that regulatory jurisdiction can sometimes turn on technical characteristics (here, distribution temperature and pressure) that have no discernible relation to rational regulatory policy.

Another decision illustrating issues that arise under state "commodity/service" definitions is that of the Texas Public Utility Commission in Bay House Investors, Ltd. vs Houston Natural Gas Corporation." There, Houston Natural Gas Corporation ("HNG") operated a system providing circulating hot and cold water to certain customers for use in their heating and air conditioning operations. Following a rate increase, a customer sought to invoke PUC rate jurisdiction over these services, claiming that they amounted to the "transmission or furnishing of water for any use" covered by an earlier version of the Texas Public Utility Regulatory Act. ${ }^{12}$

The Commission rejected this claim, holding that HNG was not transmitting or furnishing water within the statute's meaning and therefore was not subject to regulation as a water utility. Its holding was based on its conclusions that (1) HNG was actually selling thermal energy, for which

${ }^{8}$ Re: Cogeneration Development Corporation, Case No. 28502; N.Y. Public Service Commission, April 20, 1983.

${ }^{9}$ New York Pub. Serv. Law $\$ 2-22$ now excludes from its "steam corporation" definition plants that produce steam from cogeneration or alternate energy sources, defined in $\$ \S 2-2-a$. and 2-2-b.

${ }^{10}$ See March 29, 1983 Memorandum to the Commission from staff counsel in Case No. 28502. The Commission's brief ruling does not address the question whether the system might be subject to regulation under the "water system" definition quoted above.

" 4 Tex. PUC Bull. 3 (1978).

${ }^{12}$ Then, Tex. Rev. Civ. Stat. Ann. §3(c)(3). 
water circulated through a closed loop heat exchanger was simply a transfer medium; (2) HNG 's rates were based on BTU's exchanged rather than water furnished or consumed; and (3) the water was not potable as then required by the Texas statute, because it contained rust and corrosion inhibitors rendering it unfit for human consumption (although fit for heating purposes).

Bay House Investors offers useful guidance for those wishing to structure unregulated DR cogeneration ventures in two respects. First, although most state statutes do not expressly limit water utilities to those supplying "potable" water as the Texas statute did, other courts and commissions have interpreted them to include that limitation. Second, the decision highlights the distinction between regulated water distribution for consumptive purposes and unregulated distribution where water is used solely as a heat transfer medium, also familiar to some other commissions and courts. ${ }^{13}$ Intentionally or not, the distinction may reflect the difference between the natural monopoly situation which ordinarily justifies regulation of conventional water suppliers, and the competitive environment which typically characterizes cogenerators and other heat suppliers and minimizes the need to regulate their activities.

In the DR context, the Bay House Investors reasoning may have its most practical application in situations where project economics favor onsite use or wholesale sales of DR electric output to the grid (which may be exempt from regulation under PURPA), and offsite heat sales to local customers. If state statutes do not reach "heat" or "steam" sales, as many do not, then the only other basis for jurisdiction in these cases is likely to be the state's "water utility" definition, and the principles announced in this case may well determine whether or not the facility or its owner is regulated.

In addition to specifying utility commodities, state statutes usually indicate the kinds of interests in facilities supplying those commodities which will subject the supplier to regulation. These interests typically include some combination of ownership, operation, management, control, and/or use. Thus the Texas statute quoted applies to those "owning or operating," and Florida's applies to entities "owning, maintaining, or operating," equipment or facilities for supplying covered commodities. ${ }^{14}$ Oklahoma and New York statutes apply more broadly to those "owning, operating or managing" property used to furnish covered commodities ${ }^{15}$ Other states such as California, Indiana, Kentucky, and Oregon regulate persons or entities "owning, operating, managing or controlling" covered facilities. ${ }^{16}$

As these examples suggest, the precise language specifying the requisite legal relationship of the supplier to the types of facilities regulated varies from state to state. If applied literally, this language could affect the viability of some business options that utilities might consider for certain DR activities. For example, in states where the law establishes regulatory jurisdiction over those who merely "operate," "manage," or "lease" DR facilities, commercial entities may be loathe to consider leasing them from their utility or its DR affiliate to operate to supply electricity or heat to shopping centers, office parks, apartment complexes, or similar applications.

On the other hand, courts and commissions do not always interpret these provisions literally. An example is Sayre .Land Company vs. Pennsylvania Public Utility Commission, ${ }^{17}$ a case interpreting the "owning or operating" requirement of Pennsylvania's public utility statute. There, a land company owned more than $80 \%$ of the facilities of a regulated water company with which it shared common officers and directors. The water company operated the facilities and collected water charges from customers, but remitted virtually all net revenues to the land company as facility lease

\footnotetext{
${ }^{13}$ See, e.g., Williams vs. Pipe Trades Industry Program of Arizona, 100 Ariz.14, 409 P. $2 d 720$ (1964).

${ }^{14}$ See Fla. Stat. Ann. \$366.02(2); cf. \$366.02(1); emphasis added.

${ }^{15} 17$ Okla. Stat. Ann. $\$ 151$ (1995); N.Y. Pub .Serv. Law $\S \S 2-13,2-22,2-27$; cf. $\S 5$ ("owning, leasing or operating"); emphasis added.

${ }^{16}$ See e.g., Cal. Pub. Util. Code $\S 218$, 223; N.J.S.A. 48:§2-13; Ind. Code Ann. §8-1-2-1(a); Ky. Rev. Stat. Ann. \$278.010(3); Or. Rev. Stats.\$757.005(1)(a); emphasis added.

${ }^{17} 196 \mathrm{~Pa}$. Super. 417, 175 A. 2d 307 (1961); aff'd per curiam in 409 Pa. 356, 185 A. 2d 325 (1962). 
payments. The court nevertheless concluded that the land company was not a public utility (1) under the statute's "ownership" language, "merely because it owned property which it had leased to the [water company] as an operating utility," or (2) under the statute's "operating" language, because the land company itself did not actually operate the water facilities (and the water company that did was not acting its agent for that purpose). ${ }^{18}$

\section{Summary of Commodity \& Service Definitions}

State law definitions of covered commodities, services, and "ownership or control" requirements are generally similar, but individual state variations can be important in determining regulatory status. Electricity sales usually do not raise problems of definition, but steam or hot water sales from cogeneration facilities may. Where "steam" or "heat" are not specified as regulated commodities, hot water distribution might still be regulated under "water utility" definitions, but may avoid regulation if properly characterized (for example, as a non-potable heat transfer medium rather than a consumptive use). Interests subject to regulation usually include some combination of ownership, operation, management and/or control of covered facilities. The specific language of each state's statute can be critical, but may not be interpreted literally by courts and commissions.

\section{"Public Use" Requirements}

The preceding discussion focused on the kind of commodities, activities, and interests covered by state utility definitions. This section looks at the scope of activities which will trigger state regulatory jurisdiction. The question here is whether any retail distribution of electricity and/or heat to persons other than the facility's owners or operators will be characterized as "private" transactions, or as "public" service resulting in regulated utility status. Absent specific exemptions for cogeneration, renewables, or other resources (see below), these "public use" considerations may well determine the regulatory status of individual DR facilities supplying uses other than, or in addition to, the grid.

The general principles governing this area are well established:

As its name indicates, the term 'public utility' implies a public use and service to the public, and, indeed, the principal determinative characteristic of a public utility is that of service to, or readiness to serve, an indefinite public (or portion of the public as such) which has a legal right to demand and receive its services or commodities. There must be $a$ dedication or holding out, either express or implied, of products or services to the public as a class. The term precludes the idea of service which is private in its nature and is not to be obtained by the public ... Some courts, however, reject the notion that in order to be a public utility subject to governmental regulation the nature of service must be such that all members of the public have an enforceable right to demand it, and declare that business to be a public utility which in fact serves such a substantial part of the public as to make its operations a matter of public concern. ${ }^{19}$

Most state utility definitions reflect these basic principles, or at least contain language to this effect. They expressly require that covered commodities or activities be supplied "to or for the public" or conducted "for public use" (or alternatively, "for hire" or "for compensation") as a prerequisite to public utility status. The statutory language is usually similar to the following examples from California, Florida, Indiana, Kentucky, Oklahoma, and Texas, although as discussed below, state interpretations of these phrases vary considerably.

\footnotetext{
${ }^{18}$ Although held not to be a "public utility," the land company was found to be an "affiliated interest" of the regulated water company subject to limited commission jurisdiction under 66 Pa.C.S.A. $\$ \S 2101$ et seq.

${ }^{19}$ Am Jur 2d, "Public Utilities," §1, pp. 549-50; emphasis added.
} 


\section{CALIFORNIA:}

"Public utility" includes every ... electrical corporation ... water corporation and heat corporation, where the service is performed for, or the commodity is delivered to, the public or any portion thereof. ${ }^{20}$

"Public or any portion thereof" means the public generally, or any limited portion of the public, including a person, private corporation, municipality, or other political subdivision of the State, for which the service is performed or to which the commodity is delivered. ${ }^{21}$

\section{FLORIDA:}

"Public utility" means every ... legal entity ... supplying electricity or gas ... to or for the public within this state...$^{22}$

\section{INDIANA:}

"Utility" ... means every plant or equipment within the state used for ... the production, transmission, delivery, or furnishing of heat, light, water, or power, either directly or indirectly to the public ...

\section{KENTUCKY:}

"Utility" means any person ... who owns, controls, or operates or manages any facility used or to be used for or in connection with:

(a) The generation, production, transmission, or distribution of electricity to or for the public, for compensation, for lights, heat, power, or other uses; ....

\section{OKLAHOMA:}

The term "public utility" ... shall be taken to mean and include every corporation, association, company, individuals ... that now or hereafter may own, operate, or manage any plant or equipment ... directly or indirectly, for public use, or may supply any commodity to be furnished to the public. ${ }^{25}$

\section{TEXAS:}

"Public utility" or "utility" means any person, corporation [etc.] ... owning or operating for compensation in this state equipment or facilities for producing, generating, transmitting, distributing, selling, or furnishing electricity ...26

The California statute goes further than many state statutes, in that it not only recites the "public use" requirement, but attempts to define it. However, this definition provides little clarification: as in other states, that has been left to the commission and the courts. California decisions set forth the general criteria most courts apply in this area. They hold that "dedication to a public use" is normally evidenced by some act which the public reasonably relies on as a willingness to provide service on equal terms to all who apply. ${ }^{27}$ Despite the seemingly broad definition of "public

${ }^{20}$ Cal. Pub. Util. Code $\$ 216(a)$, emphasis added; see also $\$ 216($ b) ("for compensation").

${ }^{21}$ Cal. Pub. Util. Code $\$ 207$; emphasis added. The literal language of this section seems to have been disregarded by leading cases interpreting California's public use requirement; see note 28 , infra.

${ }^{22}$ Fla. Stat. Ann. $\$ 366.02(1)$; emphasis added. Compare $\$ 366.02(2)$, defining "electric utility" without reference to supplying the public, and see text below.

${ }^{23}$ Ind. Code Ann. \$8-1-2-1(g); emphasis added. Compare §8-1-2-1(a), defining "public utility" without reference to supplying the public, and see Public Service Co. vs. Aurora, 19 N.E. 2d 255, 215 Ind. 311 (1939).

${ }^{24}$ Ky. Rev. Stat. Ann. \$278.010(3); emphasis added.

${ }^{25} 17$ Okla. Stat. Ann. $\$ 151$ (1995).

${ }^{26}$ Tex. Rev. Civ. Stat. Ann., Art. 1446c-0, \$2.0011(1); cf. \$2.252 (1995).

${ }^{27}$ See, e.g., California Water \& Tel. Co. vs. Public Util. Comm., 51 Cal. 2d 478, 494, 334 P. 2 d 887 (1959); Allen vs. Railroad Comm., 179 Cal 68, 88-89, 175 P. 466 (1918). 
or any portion thereof" quoted above, where a supplier provides a specified utility service only to selected customers under individually negotiated contracts and denies the same service to others, there is no "dedication" and no resulting public utility status. ${ }^{28}$

The Florida statute, on the other hand, does not define service "to or for the public," but its courts have interpreted the phrase to mean what the California statute seems to mean. They have held that "to or for the public" means "to any member of the public" rather than "to the general public," so that the sale of electricity to a single industrial customer triggers Public Service Commission jurisdiction. This is true even though the supplier planned to build, own, and operate its generating facility on land leased from the customer. ${ }^{29}$ So broad an interpretation of the public use requirement is uncommon but not unique; the California formulation is more typical.

Indiana and Oklahoma, like a number of other states, include in their definitions plant or equipment used to furnish power "directly or indirectly" to the public. Thus the Indiana attorney general and an Oklahoma court have ruled that the owner of an electric generating plant that sells all of its output to a public utility which resells it to the general public, is itself a public utility. ${ }^{30}$ Ohio statutes do not contain such a provision, and its courts have reached an opposite result under similar circumstances. ${ }^{31}$

The general criteria most courts apply to decide whether the scope of service amounts to a public use - willingness to serve the indefinite public, service to the public indiscriminately, service to all who apply in the service area, etc. - rarely provide adequate guidance for distinguishing private from public uses. In applying them to specific factual situations, state courts and commissions usually look at a variety of factors, including:

- the number of customers served;

- the relationship between the supplier and its customers;

- the relationship between the utility services provided and any other business of the supplier, including whether separate charges are levied for the services; and

- whether the services are provided solely through private property, or involve the use of public rights of way.

Courts often state that all of these factors (and sometimes others) are relevant to the "public use" determination, and that no single one of them is controlling. Thus the determination tends to involve a good deal of judicial or commission discretion, and its outcome in individual cases is not always predictable.

The application of these factors - and the difficulty of prediction - can be illustrated by several New Jersey court decisions applying that state's public use requirement. In one case, an individual supplying himself and eight of his tenants' homes with water from a well on his property was held not to be providing water for public use. The court stressed that those receiving the service did so only by permission, and the general public had no right to demand service. Moreover, the water supply

\footnotetext{
${ }^{28}$ See, e.g., Richfield Oil Corp. vs. Pub. Util. Comm., 54 Cal. 2d 419, 354 P. 2d 4 (1960).

${ }^{29}$ See $P W$ Ventures, Inc. vs. Nichols, 533 So. 2d 281 (1988).

${ }^{30}$ 1927-1928 Op. Atty. Gen., p. 296; Southern Oklahoma Power Co. vs. Corporation Commission, 96 Okl. 53, 220 P. 370 (1923). See also Cal. Pub. Util. Code $\$ 216(c)$, "direct or indirect" services.

${ }^{31}$ See Southern O. Power Co. vs. Public Util. Comm., 110 OS 246, 143 NE 700, 34 ALR 171 (1924), and Ohio Mining Co. vs. Public Util. Comm., 106 OS 138, 140 NE 143 (1922), holding that sale to a utility for resale to the public did not render the seller a public utility.
} 
facilities were almost entirely on the supplier's private property, and tenants were not charged separately for water service. ${ }^{32}$

In another case a trailer park owner supplied water to tenants, and was capable of supplying up to 200. This also was held not to be a public use since it was incidental to the supplier's main business of running a trailer park, involved small amounts of water, and was not separately charged to tenants. ${ }^{33}$ The same result was reached in a case where a landlord supplied non-metered electricity and other utility services to an unspecified number of shopping center tenants incidental to its primary business of renting space. ${ }^{34}$

On the other hand, New Jersey courts have found "public uses" in cases involving larger numbers of customers, no landlord-tenant relationship and substantial use of public rights of way. One case $^{35}$ involved a property owners' association furnishing water to residential lot owners. The association served 48 lot owners at the time of trial, but could serve up to 400 in its subdivision and an undetermined number of others on adjoining land. The water system crossed public rights of way, and was used to induce the public to buy lots in the development.

The court found that lots - and therefore association memberships and water service - were available to the public without restriction. It wrote that the "public use" determination depends on "the character and extent of the use and not upon agreements or understandings between the supplier and those supplied," and held that the association was engaged in a public use and subject to PUC jurisdiction. ${ }^{36}$

Another case of potential interest for DR ventures is Drexelbrook Associates vs. Pennsylvania PUC, ${ }^{37}$ a 1965 Pennsylvania Supreme Court decision. Drexelbrook was a landlord proposing to supply gas, electric and water service to 1200 residential tenants, nine retail stores and an athletic club. The gas and electric service was to be metered, while the water service was to be included in the tenants' rent. Reversing a Pennsylvania PUC decision, the court held that these arrangements did not constitute service "to or for the public" under Pennsylvania's statute.

The court stated that neither the number of customers served nor the method of charging for service was conclusive in determining public utility status. It adopted the traditional view that "service to or for the public" contemplates service to an "indefinite public" which has the right to demand it. Despite their large number, Drexelbrook's tenants comprised a "defined, privileged and limited group," whose right to demand service arose strictly from their status as tenants, not as members of the general public. ${ }^{38}$

${ }^{32}$ Junction Water Company vs. Riddle, 108 N.J. Eq. 523, 155 A. 887 (1931). But see Re: Glen Wild Lake Co., 89 PUR 3d 204 (N.J. Board of Public Utility Commissioners, 1971), where a company supplying electricity to 175 lessees through private property was held to be engaged in a public use.

${ }^{33}$ Freehold Water \& Utility Company vs. Silver Mobile Home Park, 68 PUR 3d 523 (N.J. Board of Public Utility Commissioners, 1967).

${ }^{34}$ Antique Village Inn vs. Paciti, 160 N.J. Super. 554, 390 A. 2d 681 (1978)

${ }^{35}$ Lewandowski vs. Brookwood Musconetcony River Property Owners Association, 37 N.J. 433, 181 A. 2 d 681 (1982).

${ }^{36}$ Id., at 445-446. See also Petition of New Jersey Natural Gas, 109 N.J. Super. 324, 263 A. 2d 174 (1970), finding a public use where the utility distributed metered fuel oil through a pipeline crossing public rights of way to 950 homes. In finding a membership association saving its own members engaged in a public use, the Lewandowski case departs from the rule in many states which exempt cooperatives under similar circumstances. However, it is consistent with other New Jersey cases which have found "public uses" and imposed regulation on cooperatives. (See Jersey Central Power and Light Co. vs. Tri-County Rural Electric Co., 38 PUR 48 (N.J. Board of Public Utility Commissioners, 1941) [thousands of customers; virtually unrestricted coop membership; public property]; Re: Cedar Glen West Inc., 70 PUR 3d 115 (N.J. Board of Public Utility Commissioners, 1967) [water service to over 500 units; separate but unmetered charges].)

$37418 \mathrm{~Pa} .430,212$ A 2d 237 (1965).

${ }^{38}$ Id.; see also C.E. Dunmire Gas Company, Inc. vs. Pennsylvania PUC, Pa. Cmnwlth., 413 A. 2d 473, a 1980 case holding that retail gas service to only 45 customers was service "to or for the public", since the supplier served an "indefinitely open" customer class, limited only by available gas supplies. 


\section{Summary of "Public Use" Requirements}

Most state utility statutes require service "to or for the public" or "for public use" as a condition of public utility status and regulatory jurisdiction. The scope of activities considered "public" can be important for DR facilities serving a limited number of nearby customers under arrangements different from those of more conventional energy suppliers. Courts and commissions generally have considered "public" service to mean service to the "indefinite" public - i.e., to anyone who applies within the geographic area the supplier can serve - but decisions vary considerably from state to state. No single factor controls the "public use" determination. Courts tend to consider the number of customers served, the supplier/customer relationship, the relationship of utility services to the supplier's other activities, and the use of public property in providing services. How these factors will be applied in individual situations is often hard to predict - especially in limited distribution configurations such as shopping centers, office parks, residential subdivisions or similar applications which some DR facilities might serve. In these situations, resolution of the "public use" issue can frequently determine regulatory status, unless some specific exemption applies.

\subsubsection{State Exemptions From Regulation}

If DR owner/operators desire to supply retail electricity (and/or steam or hot water) from facilities covered by state utility definitions in situations considered "public uses," then they will be subject to state regulation unless some other state law provision exempts their activities. This section discusses exemptions commonly available under existing state regulatory schemes.

The exemptions considered here are usually statutory, but may also be the product of administrative or judicial decisions. They fall generally into three categories. ${ }^{39}$ The first consists essentially of refinements and codifications of the "public use" doctrine already discussed. These exemptions cover specific "limited distribution" situations, and can bear directly on utility choices among structures for their own or their customers' onsite DR activities.

The second category applies to certain types of self-regulated entities, such as municipal corporations and cooperative associations, which are thought to be adequately supervised and controlled by those they serve. These exemptions are less useful to utilities as structural guides than they may be as indicators of potentially attractive opportunities to market DR facilities.

The third category of exemptions reflects state policy choices to encourage efficiency and alternative energy sources, usually cogeneration and/or renewables. Where they exist, these exemptions can also bear directly on utility choices as to the scope and structure of DR activities, as well as on market identification. These exemptions are generally tailored for specific types of resources: where DR activities proceed under conventional legal and regulatory regimes these may offer useful models for new legislation tailored to particular DR needs, to supplant patchwork exemptions intended for other purposes.

\section{"Limited Distribution" Exemptions}

Many states explicitly exempt some service configurations which would be exempt implicitly under most interpretations of the "public use" doctrine. Of those relevant to DR, the most common is service for the producer's own use and that of its tenants and/or employees, and not for resale to

\footnotetext{
${ }^{39}$ A fourth category of exemption appears in the new Texas Public Utility Regulatory Act of 1995, which exempts from state regulatory jurisdiction power marketers and wholesale generators (EWGs) which the Energy Policy Act of 1992 (EPAct) exempts from federal Public Utility Holding Company Act requirements. The Texas EWG definition is similar but not identical to EPAct's, and in any case requires that those claiming EWG status have applied to the FERC or registered as EWGs under the Holding Company Act. "Power marketer" under the Texas Act means a person who owns power for the purpose of buying and selling it; does not own generation, transmission, or distribution facilities in Texas or have a certificated service area; and has been granted FERC authority to sell at market-based rates or registered as a power marketer under the Texas Act. See Tex. Rev. Civ. Stat. Ann., Art. 1446c-0, \$2.0011 (1995).
} 
others. This exemption is often, although not always, limited to service provided solely on or through private property. The New York, Pennsylvania and Texas statutes illustrate several variations found among these exemptions:

\section{CALIFORNIA:}

"Electrical corporation" includes every corporation or person owning [etc.] any electric plant for compensation within this state, except where electricity is generated on or distributed by the producer through private property solely for its own use or the use of its tenants and not for sale or transmission to others.

"Electrical corporation" does not include a corporation or person employing cogeneration technology or producing power from other than a conventional power source for the generation of electricity solely for ...

(2) The use of or sale to not more than two other corporations or persons solely for use on the real property on which the electricity is generated or on real property immediately adjacent thereto, unless there is an intervening street... and [certain conditions apply]. ${ }^{40}$

\section{NEW YORK:}

The term "electric corporation"....includes every corporation [etc.] owning, operating or managing any electric plant except where electricity is generated or distributed by the producer solely on or through private property for ...its own use or the use of its tenants and not for sale to others; or except where electricity is generated by the producer solely from one or more co-generation, small hydro, or alternate energy production facilities or distributed solely from one or more of such facilities to users located at or near a project site. ${ }^{41}$

\section{PENNSYLVANIA:}

The term "public utility" does not include:

(i) Any person or corporation, not otherwise a public utility, who or which furnishes service only to himself or itself. ${ }^{42}$

\section{TEXAS:}

...The term ["public utility," "utility" or "electric utility"] does not include any person or corporation not otherwise a public utility that:

(A) furnishes the service or commodity described in this section only to itself, its employees, or tenants as an incident of such employee service or tenancy, when such service or commodity is not resold to or used by others;

(B) owns or operates in this state equipment or facilities for producing, generating, transmitting, distributing, selling, or furnishing electric energy to an electric utility, if the equipment or facilities are used primarily for the production and generation of electric energy for consumption by the person or corporation.

(C) owns or operates [certain recreational vehicle parks]. ${ }^{43}$

\section{Own Use or Tenants' Use}

Many states provide exemptions nearly identical to the "own use or use of its tenants" provisions quoted above. Questions concerning their scope arise where there is distribution to persons who are not the producer's tenants, or where there is distribution to tenants through public property (typically public streets).

\footnotetext{
${ }^{40}$ Cal. Pub. Util. Code $\$ 218(a)$, (b); emphasis added.

${ }^{41}$ N.Y. Pub. Serv. Law \$2-13; see also \$2-22 and \$2-27, providing similar exemptions for steam and water corporations.

${ }^{42}$ Pa. C.S.A. $\S 102$, "Public utility."

${ }^{43}$ Tex. Rev. Civ. Stat. Ann., Art. 1446c-0, §2.0011(1). (1995)
} 
An example of the first situation is Re: Central Hudson Gas \& Electric Corp., ${ }^{44}$ where the New York Public Service Commission (PSC) held that the exemption did not apply. There, a corporation purchased electricity from an electric utility and in turn supplied one other corporation, at cost, through a separate meter. Both corporations conducted their business on private property owned by their common landlord, but the recipient was not the supplier's tenant. The supplier was therefore subject to Commission jurisdiction.

An example of distribution through "public" property is Re: Gair Realty Corporation. ${ }^{45}$ There the New York PSC indicated that the "private property" exemption would be interpreted quite literally. It would not apply if a supplier of purchased electricity and steam distributed them across a public street, but would apply if the supplier happened to own property on both sides of the street under deeds which conveyed title up to the street's center.

Neither of these cases focused on the statute's language (common to many states) which limits the "own use/ tenant" exemption to situations involving distribution "by the producer". Both involved distribution by one who was not the producer in the usual sense of that term, but the PSC did not address that issue on the facts presented. However, the issue could arise in the DR context. For example, if a utility or its affiliate chooses to own DR facilities to be operated onsite by building owners interested in distributing electricity or heat to their tenants, the building owner could be subject to regulation as an "operator or manager" ${ }^{145}$ - but could be ineligible for the "own use/tenants" exemption on the ground that only the owner of the facility is "the producer" within the meaning of these provisions. Other interpretations are possible; this one is suggested simply to underscore the need for careful analysis of specific statutory language in this area.

The New York PSC also considered the "own use/tenants" exemption in another case involving steam distribution. There it concluded that New York Medical College's furnishing of steam from its own plant to a county building within the same medical complex - but across a public street and under county property - rendered it a "steam corporation" subject to regulation. The PSC staff opinion supporting the ruling observed that the Commission had interpreted the "on or through private property" language of similar statutes literally, and would do so here as well. ${ }^{47}$ The PSC did, however, recognize that the College was "primarily engaged in carrying on a business other than owning, operating, managing or controlling [a] steam plant," and so exercised its authority to make rules exempting entities in similar situations from accounting and reporting requirements on their "incidental" steam operations.

\section{Incidental Sales}

Exemptions for sales incidental to the supplier's main business and/or sales of surplus production exceeding the supplier's onsite needs are provided in a number of states. These exemptions are usually created by courts in the process of applying the "public use" test, but are sometimes codified in statutory provisions as well. ${ }^{48}$ They may be broader than the rather rigid formulations of the "own use/tenant" exemptions described above, and may apply where the former do not. Incidental or surplus sales exemptions can thus be useful in specific cases, but still may not cover other situations considered promising for DR installations.

\footnotetext{
4430 PUR (N.S.) 257 (N.Y. Public Service Commission, 1939).

45 PUR 1931 D, at pp. 390-396; see also PSC Case 19276, Oct. 21, 1958.

${ }^{46}$ See text accompanying notes 14-16 supra.

${ }^{47}$ See Declaratory Ruling in Case No. 28523, Re: New York Medical College; N.Y. Public Service Commission, July 12 , 1983.

${ }^{48}$ See, e.g., Nev. Rev. Stat. $\$ \$ 704.310, .320$; Story vs. Richardson, 186 Cal. 162, 198 P. 1057; Arizona Corp. Comm. vs. Nicholson, 108 Ariz. 317, 497 P. 2d 815.
} 


\section{Exclusion of Existing Public Utilities}

The Pennsylvania and Texas statutes quoted above highlight the fact that statutory exemptions sometimes exclude existing public utilities from their coverage. Both statutes exempt only persons or corporations "not otherwise a public utility". The intention seems to be to ensure that other activities of existing regulated utilities will not be exempted by reason of engaging in activities which would be exempt if others conducted them. But the effect could be to preclude utilities from conducting some DR activities as unregulated operations within their existing structure, even though carefully segregated from regúlated functions.

\section{Small Scale Systems}

Final examples of "limited distribution" exemptions are those which describe small-scale utility systems. The following Oregon provisions are illustrative:

...the term "public utility" does not include: ...

(d) Any corporation, company, individual or association of individuals providing light, heat or power to less than 20 customers....

(f) Any water utility serving less than 300 customers at an average annual residential rate of $\$ 15$ per month or less, which provides adequate and nondiscriminatory service. ${ }^{49}$

A number of states provide exemptions of this kind. They usually limit service to very few customers; Oregon's "small water system" provision is liberal in exempting service to as many as 300. And they usually apply only to water systems; again Oregon's statute is atypical in exempting the furnishing of "light, heat or power" (even to just 20 customers). Where similar exemptions exist, they offer an alternative basis for creating unregulated "utility" facilities - if they happen to cover the DR outputs to be sold, and if their size, revenue and other restrictions coincide with the technical and economic requirements of proposed projects.

\section{Self-Regulation Exemptions}

These exemptions apply primarily to municipal or other publicly-owned utilities, and to cooperatives, mutual water companies and non-profit entities controlled by their members. They are common and generally straightforward, and so will be noted only briefly here. They may be more relevant to identifying $D R$ markets than to structuring utility $D R$ projects: public or non-profit entities that can benefit from these exemptions may be more receptive than others to owning and operating DR and distributing their output.

Most states exempt utilities owned and operated by the state, counties, cities or other political subdivisions, at least as to service furnished within the entity's boundaries. ${ }^{50}$ Some states, such as Ohio and Texas, confer substantial authority on municipalities over service terms and rates charged by utilities operating within their boundaries, subject to varying degrees of state utility commission review. ${ }^{51}$ In states with similar schemes, the substance of any DR regulation could vary depending on whether the local entity or the state PUC exercises jurisdiction.

\footnotetext{
${ }^{49}$ Or. Rev. Stats. $\$ 757.00 \mathrm{~S}(2)$.

${ }^{50}$ See, e.g., Cal. Const., Art. 12, §3; Ind. Code $\S 8-1-2-1(a) ;$ Ohio Rev. Code $\$ 4905.02$.

${ }^{51}$ See, e.g., Ohio Const. Art. XVIII, $\S 4$ and Ohio Rev. Code Ann. $\$ \$ 715.34$ and 4909.34; Tex. Rev. Civ. Stat. Ann., Art. $1446 c-0, \S \S 2.101$ et ség.
} 
Many states also exempt from regulation cooperatives and certain nonprofit entities (or entities providing non-profit utility services). ${ }^{52}$ These provisions usually are limited to service to members: service to non-members will forfeit the exemption. Some states do specifically include cooperatives as regulated public utilities even when their service is limited to members, but these are probably in the minority. Like the other self-regulating exemptions, those for cooperatives and nonprofit entities might be useful for DR purposes where such structures are already in place or where they make sense as electric or heat distribution vehicles for reasons independent of their regulatory status.

\section{Alternative Energy Exemptions}

A number of states have enacted statutes to encourage alternative energy development, usually focusing on cogeneration and/or renewable resource facilities. The statutes vary considerably in their approaches and coverage, but some include full or partial regulatory exemptions for such facilities and their owner/operators. For entities considering DR activities that employ these resources, these exemptions may provide the broadest and most flexible avenues for structuring unregulated DR ventures.

California, Connecticut, Michigan, New York, and Texas are among the states whose statutes provide some form of exemption for alternative energy facilities. The Texas provision, carried over into its 1995 legislation overhauling the state's public utility law, is probably the most straightforward. It provides simply that the state's definition of "electric utility" (or "public utility" or "utility") may not be construed to include "a qualifying facility". A "qualifying facility" is defined to include qualifying cogeneratọrs and small power producers, as defined in the Federal Power Act. ${ }^{53}$

Thus, the Texas statute exempts cogenerators which qualify under these federal FPA/PURPA standards from regulation as electric utilities under state law - that is, from regulation as to retail electric sales not covered by PURPA's own wholesale exemption. Qualifying cogenerators considering heat distribution might note that the statute exempts them only from its electric utility definition. Under the new Texas law, steam and heat are not "utility" commodities, and water furnished for heating or cooling purposes will not be regulated under the state's water utility definition (see Bay House Investors, discussed earlier), so this QF exemption appears to cover the only situation that might otherwise remain subject to state regulation. However, exemptions limited to electric utility status could present problems in states which regulate steam, heat or hot water utilities.

Connecticut expressly exempts "private power producers" from its definitions of "public service company" and "electric company". "P4 "Private power producers" include, among other entities, certain utility or utility holding company subsidiaries which generate electricity solely through their ownership of $50 \%$ or less of private power production facilities. "Private power production facilities" are facilities which generate electricity solely through cogeneration yielding useful thermal output that is at least $20 \%$ of total energy output, or solely through renewable energy sources, or both. ${ }^{55}$

Michigan statutes likewise exempt from public service commission jurisdiction owners of "renewable resource power production facilities" of up to $30 \mathrm{MW}$ that use biomass, waste, wood,

52 See, e.g., Ohio Rev. Code Ann. §4905.02; 66 Pa. C.S.A. $\$ 102$ and 15 Pa. C.S.A. $\$ 12402$ et seq.; Tex. Rev. Civ. Stat. Ann., Art. 1446c-0, $\$ 2.2011$.

${ }^{53}$ Tex. Rev. Civ. Stat. Ann., Art. 1446c-0, $\$ 2.0011(1)$, (4), (5), referencing Federal Power Act $\S \S 3(18)(C)$ and 3(17)(D); see note 4, supra.

${ }^{54}$ Conn. Gen. Stats. Ann. $\$ 16-19(a)(4),(a)(8)$.

${ }^{55}$ Conn. Gen. Stats. Ann. $\$ 16-243 \mathrm{~b}$. This Connecticut "mini-PURPA" statute also requires utilities to purchase power at full avoided cost from, interconnect with, and provide backup to private power producers, and it empowers the commission to set long-term schedules for purchases from "small renewable power projects" of up to $5 \mathrm{MW}$ capacity fueled by wind, hydro, biomass, or other solar resources (other than wood). See Conn. Gen. Stats. Ann. $\S \S 16-243 a$ and b. 
hydro, wind, and/or other renewables, provided that the owner was not a public utility prior to the facility's construction, and the facility's ownership is "ancillary to" its financing. ${ }^{56}$

California's Public Utilities Code also exempts a variety of cogeneration and renewableresource-based activities. Among other things, the code illustrates the need to examine whether available exemptions are co-extensive with the scope of activities subject to regulation. Section 216 sets forth California's generic "public utility" definitions. Following its traditional recitation of covered commodities and services and "public use" requirements, section 216 provides the following alternative energy exemptions:

(d) Ownership or operation of a facility which employs cogeneration technology or produces power from other than a conventional power source or the ownership or operation of facility which employs landfill gas technology does not make a corporation or person a public utility, within the meaning of this section, solely because of the ownership or operation of such a facility.

(e) Any corporation or person engaged directly or indirectly in developing, producing, transmitting, distributing, delivering, or selling any form of heat derived from geothermal or solar resources or from cogeneration technology to any privately owned or publicly owned public utility, or to the public or any portion thereof, is not a public utility within the meaning of this section solely by reason of engaging in any of those activities.

Reduced to essentials, subsection (d) above states that the "ownership or operation" of a cogeneration or landfill gas facility or nonconventional power source will not by itself make anyone a public utility. However, "ownership and operation" are not the only bases for public utility status in California. Separate definitions of "electrical," "heat" and "water" utilities define these to include anyone "owning, controlling, operating or managing" plant and equipment for supplying the covered commodities. ${ }^{57}$ So the first question (unanswered by any authority we have found) is whether subsection (d) would exempt persons such as landlords who might "control" or "manage" cogeneration facilities without owning or operating them (or whether "operating" is equivalent to "controlling" or "managing").

The question has arisen whether the "ownership or operation" exemption is strictly limited to those activities, or whether it covers distribution and sale of cogeneration output as well. The question is reasonable based on the statute's language. However, it is something of a non sequitur when one considers the basic structure of public utility regulation outlined in these pages. Since "ownership and operation" of facilities, without more, would not render anyone a utility to begin with (absent distribution or sale "to the public"), the exemption appears meaningless if it does not apply to activities such as distribution and sale which actually trigger regulatory jurisdiction.

Like language in some other state statutes, subsections (d) and (e) both provide only that the status and activities described will not by themselves result in public utility status. Thus, neither exempts existing public utilities whose other activities independently subject them to regulation.

California law would be complicated enough if these were its only alternative energy exemptions, but they are not. Section 218 (see partial text accompanying note 40, above) separately defines "electrical corporations" subject to commission jurisdiction, and independently exempts generators employing cogeneration, landfill gas, or other nonconventional technologies to generate power for their own or their tenants' use, or for the use of not more than two others on or adacent to the generation site, or if they sell or transmit power to an electric utility or public agency.

The California provisions illustrate the intricacy of some state exemption schemes, and the point that even states regarded as leaders in alternative energy development may have overlapping and inconsistent legislation in this area, adopted piecemeal in response to political or other

\footnotetext{
${ }^{56}$ Mich. Stats. Ann. $\$ 22.13(6 \mathrm{~d})(1)$, (2).

${ }^{57}$ Cal. Pub. Util. Code $\$ \$ 218,224$, and 241 , respectively.
} 
exigencies. This underscores the importance for those interested in DR development of taking the initiative to shape coherent legislation, rather than trying to structure DR programs around a potpourri of laws and regulations designed in other times for other purposes.

\section{Summary of State Exemptions from Regulation}

States provide a variety of exemptions from public utility status. These remain good law in most states today, notwithstanding moves toward a more competitive electricity environment. Some, like the "own use/tenants" and "incidental sales" exemptions, essentially refine or codify the traditional "public use" requirement. These can be useful for specific projects that fall within them, but they are not likely to create general markets or support widespread unregulated DR activities. Other exemptions, like those for publicly and cooperatively-owned utilities, substitute "ratepayer" control for commission regulation. Since many electric utilities must be responsible to investors as well as ratepayers, these exemptions may be of interest chiefly as indicators of potential DR markets.

The most promising state regulatory exemptions, and the most useful models for future action, may be those enacted to encourage cogeneration and other alternative energy production. They are likely to be broader than some other exemptions, and more focused on the specific needs of DR development. However, their scope varies considerably from state to state: as enacted, some may not benefit conventional public utilities, and some may not cover all generation configurations of interest to $\mathrm{DR}$ proponents. Those willing to take the initiative here may have opportunities to educate legislators and regulators to support DR incentives that could benefit DR investors, utility ratepayers, and the general public alike.

\subsection{STATE FACILITY SITING AND CERTIFICATION}

This section reviews the potential application to DR facilities of state laws governing energy facility siting, certificates of public convenience and necessity, and related certification procedures designed to avoid duplication of service and allocate retail service territories. There are not always clear distinctions among these siting and certification laws: they deal with similar subjects, and what some states call facility siting others refer to as certification. In general, however, facility siting laws focus on the facility itself, whereas certification laws may have a broader reach, discussed below.

\subsubsection{Facility Siting Laws .}

Of fourteen states surveyed on this topic, fewer than half have specific statutes governing electric facility siting per se, although a few others have statutes addressing environmental compatibility of such facilities. The facility siting laws generally require advance approval by a state agency for the construction of electric power facilities, variously defined. Most of the statutes exempt small facilities from their requirements, and some exempt facilities using renewable resources and/or qualifying cogeneration.

Exemptions for "small" facilities typically cover facilities under 50 or $75 \mathrm{MW}$ (or, in Washington state, ${ }^{58}$ under $250 \mathrm{MW}$ ), so most DR facilities are likely to be exempt on that ground alone. For example, California's Warren-Alquist Act prohibits construction or modification of any "facility" without approval from the California Energy Commission. "Facility" means a power

\footnotetext{
${ }^{58} \mathrm{RCW} \S \S 80.50 .060$ and $80.50 .020(14)(\mathrm{a})$.

${ }^{59}$ Cal. Pub. Resources Code $\$ 25500$. Facility siting approval, referred to as "certification" in the statute, resides in the Energy Commission, while authority to issue certificates of public convenience and necessity resides in the California Public Utilities Commission (see Cal. Pub. Util. Code $\$ 1001$ et seq.)
} 
plant of at least $50 \mathrm{MW}$ capacity using any source of thermal energy, and expressly excluding wind, hydroelectric, and solar photovoltaic generating facilities. ${ }^{60}$

Ohio's Power Siting law likewise applies only to "major utility facilities," defined to include electric generating plants and associated facilities of $50 \mathrm{MW}$ capacity or more. ${ }^{61}$ Florida's law similarly applies to "electrical power plants," there defined to mean "any steam or solar electrical generating facility using any process or fuel" and including associated facilities and transmission lines, but excluding facilities under $75 \mathrm{MW}$ capacity. ${ }^{62}$ Connecticut's statute excludes certain non-utilityowned renewable generators of up to $1 \mathrm{MW}$ capacity, as well as certain cogenerators of up to 25 MW capacity. ${ }^{63}$

\subsubsection{Certification Laws}

State certification statutes include some that require "certificates of public convenience and necessity" as a condition of constructing new utility facilities or furnishing utility service; some that establish certification for retail service territories; some that call for certification of environmental compliance; and some that combine several of these elements.

Certificates of public convenience and necessity (CPCNs) and certified territories are mechanisms by which many states control entry into markets for utility services. Market entry control is based on traditional natural monopoly theory. Centralized utilities invested substantial capital in fixed generation, transmission, and distribution facilities needed to furnish essential services to the public. The cost per unit of service historically declined as the number of customers using the system increased. As an economic matter, these characteristics favored larger firms capable of achieving economies of scale and scope, and resulted in domination of the service area by a single firm, or "natural monopoly."

State utility regulation has sought to protect the public's interest in essential services from potential abuses by natural monopoly providers through the device of the "franchised monopoly." Under this concept, regulatory agencies grant a utility the right (often exclusive) to supply a particular commodity or service within a designated geographic territory. To protect that right and avoid duplication of services at consumer expense, regulators control market entry by granting or denying certification. Where certification is required, suppliers cannot lawfully build facilities, initiate service, or provide service in others' certificated areas without complying with statutory requirements.

\section{Certificates Of Public Convenience And Necessity}

\section{Application}

Some CPCN statutes apply only to public utilities, or only to some kinds of public utilities, proposing to build new facilities or modify existing ones. For example, California's statute prohibits most types of utilities (including gas, electric, telephone, telegraph, railroad, water, and sewer utilities) from beginning construction of "a line, plant, or system, or any extension thereof, without first having obtained from the [Public Utilities] commission a certificate that the present or future

\footnotetext{
${ }^{60}$ Id., $\$ \S 25110,25120$. "Facility" also includes an "electric transmission line", defined to mean a line carrying power from a thermal powerplant in the state to a junction point with any interconnected transmission system, excluding certain line replacements and ancillary equipment; see Id., $\$ 25107$.

${ }^{61}$ Ohio Rev. Code Ann. $\$ 4906.01$. "Major utility facilities" also include transmission lines and associated facilities of 125 $\mathrm{kV}$ capacity or more.

${ }^{62}$ Fla. Stat. Ann. $\$ \$ 403.503(12), 403.506(1)$.

${ }^{63}$ Conn. Gen. Stat. Ch. 277(a), Public Utility Environmental Standards Act, $\$ 16-50$ i.
} 
public convenience and necessity require or will require such construction. ${ }^{2064}$ The Indiana CPCN statute applies to "public utilities" generally, and the Kentucky statute to those meeting its "utility" definition. ${ }^{65}$ Florida's statute appears to reach only telecommunications utilities and gas pipelines. ${ }^{66}$

Other CPCN statutes covering electric utilities are phrased more broadly to apply to the rendering of public utility services rather than, or in addition to, the construction or modification of physical facilities. Texas, for example, prohibits public utilities from rendering service directly or indirectly to the public under a franchise or permit without obtaining a certificate that the public convenience and necessity require "such installation, operation, or extension." It also prohibits "retail public utilities" from furnishing service to areas served by another retail utility without obtaining a $\mathrm{CPCN}^{67}$

\section{Exemptions}

Most state laws exempt certain types of construction or service extensions from CPCN requirements. For example, California exempts extensions within cities already served, or to areas contiguous to existing facilities not served by another utility, or to territories already served if necessary in the ordinary course of business. ${ }^{68}$ Texas provides similar exemptions, limited to devices for interconnecting existing facilities or transmitting from such facilities to retail customers. ${ }^{69}$ Indiana excepts from its CPCN requirement generating facilities primarily for their owner's own use and not selling to the public, as well as qualifying alternate energy, cogeneration, and small hydro facilities. ${ }^{70}$

Similarly, to implement a 1995 legislative mandate to promote renewable energy technologies, the Texas Public Utility Commission has proposed to exempt from its CPCN requirements: a new generation facility that produces less than 87,600 megawatt-hours annually [i.e., a $10 \mathrm{MW}$
baseload generator] and that exclusively relies on a renewable energy technology.

"Renewable energy technology" means:

... any technology that exclusively relies on an energy source that is naturally regenerated over a short time scale and derived directly from the sun (solar-thermal, photochemical, and photoelectric), indirectly from the sun (wind, hydrpower, and photosynthetic (stored in biomass)), or from other natural movements and mechanisms of the environment (geothermal and tidal energy)....

The new Texas statute is the only one disclosed by this research that expressly refers to "distributed resources," not in the CPCN context but in a provision identifying resources that utilities can procure outside the competitive solicitation process the statute otherwise requires. Under the Commission's proposed rules:

A distributed resource is a generation, storage, or targeted demand-side resource, generally between one kilowatt and 10 megawatts, located at a customer's site or near a load center, and connected at

${ }^{64}$ Cal. Pub. Util. Code $\$ 1001$.

${ }^{65}$ See Ind. Code Ann. §8-1-8.5-2; cf. Ky. Rev. Stat. Ann. \$278.020(1), (2), (3).

${ }^{66}$ See Fla. Stat. Ann. $\$ \$ 364.33,403.9401$.

${ }^{67}$ Tex. Rev. Civ. Stat, art 1446c-0, $\$ 2.252$ (a),(b). Qualifying cogenerators selling retail electricity to the sole purchaser of their thermal output are not retail public utilities for purposes of this requirement; see $\$ 2.251$.

${ }^{68}$ See, e.g., Cal. Pub. Util. Code $\$ 1001$.

${ }^{69}$ Tex. Rev. Civ. Stat., art 1446c-0, $\$ 2.253$.

${ }^{70}$ Ind. Code Ann. $\S 88-1-8.5-7,8-1-2.4-5$.

${ }^{71}$ Tex. Pub. Util. Com. Proposed Rule §23.31(c)(2)(I); see alsoTex. Rev. Civ. Stat., Art 1446c-0, §2.051(v); emphasis added.

${ }^{72}$ Id., $\$ 23.3$. 
the distribution voltage level $(60,000$ volts and below), that provides geographic advantages to the system, such as deferring the need for upgrading local facilities. ${ }^{73}$

In its discussion of the rules, the Commission proposes:

that electric generation facilities of less than ten megawatts operating with renewable resources and distributed resources that exclusively employ renewable energy technologies be exempt from the requirements of a certificate of convenience and necessity. ${ }^{74}$

The Commission notes that it may be appropriate to distinguish between large and small resources, and solicits comment on the following questions:

Are there small-scale, but otherwise economical renewable resource projects that are unlikely to bid into a utility resource solicitation? Do the costs and benefits of small generating facilities warrant exemption from the regulatory oversight required for larger combustion-based generating resources? Should the commission allow generation facilities of less than ten megawatts operating exclusively with renewable resources to make retail sales without a certificate of public convenience and necessity, and if so, to what transmission and standby services would such entities and their customers need access? Should utilities be required to have a standard offer for purchase from small-scale resource providers? ${ }^{75}$

Kentucky's CPCN exemption is also noteworthy for DR purposes because it excepts from CPCN requirements "retail electric suppliers for service connections to electric-consuming facilities located within its certified territory," as well as ordinary extensions of existing systems in the usual course of business. The Kentucky statute, like some others that establish retail service territories (see below), defines "electric-consuming facilities" as facilities that use electricity "from a central station source" (not defined). ${ }^{76}$ This could mean that service connections to consumers from distributed resources would not qualify for the exemption, and would require CPCNs. However, the CPCN requirement applies only to the construction of facilities that furnish utility services "to the public," so DR facilities might not need certification in any event. ${ }^{77}$

Utilities considering DR activities within the regulated utility structure will need to determine whether their existing certification, if any, is broad enough to cover the types of DR facilities to be built or services to be offered. If not, or if the utility is considering pursuing DR activities through a separate nonutility entity, then it will need to determine whether the activities contemplated require certification under the particular language of its state's law - e.g., construction or operation of specified facilities or rendering of public utility services - or are exempt under the types of exemptions just mentioned.

\section{CPCN Standards \& Possible Challenges}

States that require CPCNs adopt their own standards for determining whether "public convenience and necessity" will be served by new facilities or services. Historically, most CPCN applicants have been required to show that:

- there is adequate demand for the facility or service;

- they have sufficient capacity to meet that demand;

73 Id. Tex. Rev. Civ. Stat. art $1446 \mathrm{c}-0, \$ 2.051(\mathrm{x})$ limits distributed resources that can be added outside the normal solicitation process to those "located at or near the point of consumption, if they are less costly than transmission extensions or upgrades." The statute has been criticized as unnecessarily restrictive in limiting this provision to renewable $\mathrm{DR}$, and to $\mathrm{DR}$ that are less costly than transmission upgrades, since this may neglect extemalities and in any case may exclude DR that would be cost-effective by other measures.

${ }^{74}$ Id., at p. 2.

${ }^{75}$ Id.

${ }^{76}$ Ky. Rev. Stat. Ann. $\$ 278.020(1) ; \$ 278.010(8)$.

${ }^{n}$ Id., $\$ 278.020(1)$; see Cumberland Valley Rural Elect. Coop. Corp. vs. Public Serv. Comm'n, 433 S.W.2d 103 (Ky. Ct. App., 1968), and earlier discussion of "public use" requirements. 
- suitable financing is available to complete their plans;

- their costs and proposed charges are reasonable; and

- the facility or service is needed and will not duplicate existing services.

Other standards have also emerged under newer CPCN schemes. Indiana, for example, conditions granting a $\mathrm{CPCN}$ on a commission finding regarding estimated construction, purchase, or lease costs, and consistency with a commission or utility-specific expansion plan. ${ }^{78}$ Texas directs its commission to consider the effect of granting a $\mathrm{CPCN}$ for utility-owned resource additions on both the recipient utility and any public utility of the same kind already serving the area. It also requires consideration of community, recreational, historical, and aesthetic values, environmental integrity, and effects on consumer service and cost. The commission must grant the certificate if it finds that:

- the proposed addition is necessary;

- it is the best and most economical technology choice for the service area; and

- cost-effective conservation or alternative energy sources cannot meet the need. ${ }^{79}$

The first of these factors appears neutral as to $\mathrm{DR}$, but the second and third could provide a competitive advantage for some kinds of cost-effective DR projects.

When considering the more traditional standards noted above for granting CPCNs, the last two mentioned - that the facility is needed and will not duplicate existing services - are probably the most germane to DR development. Where, for example, a DR provider proposes to develop a resource or install a facility in an area in which another provider offers a similar service there could be an objection that the service is not needed, or that it duplicates service already being provided.

Such challenges usually have been successful only where the challenger offers an identical commodity or service (or the same commodity in a different physical state, such as natural versus liquefied gas). If that threshold determination is made, then the new entrant typically must show that the existing provider has failed to render adequate service at reasonable rates - often a difficult showing to make.

Two Pennsylvania cases illustrate approaches that courts and commissions have commonly taken to these issues. The first is Mobilfone [etc.] vs. Pennsylvania PUC, ${ }^{80}$ where an applicant sought a $\mathrm{CPCN}$ to provide mobile radiotelephone service in portions of northeastern Pennsylvania. Another carrier providing service in the same area protested the application.

The court first observed that under Pennsylvania's certification statute, the applicant had the burden to show that (1) the proposed service was needed; (2) the applicant was financially and technically able to provide it; and (3) the existing service was inadequate. However, previous Pennsylvania decisions had established that

where the proposed service is different than the existing service, the applicant need not establish inadequacy of existing service in order to secure a certificate of public convenience, and that proof of public necessity for the service alone may support the certificate. However, where the proposed service is identical to existing service, a showing of inadequacy is required. ${ }^{81}$

The applicant here offered both one-way and two-way radio service. If the protesting party had offered only one-way service, the court indicated that the services would not have been "identical."

\footnotetext{
${ }^{78}$ Ind. Code Ann. §8-1-8.5-5.

${ }^{79}$ Tex. Rev. Civ. Stat., Art. 1446c-0, \$2.253; emphasis added.

${ }^{80} 458$ A.2d 1030 (Pa. Cmwlth., 1983)

${ }^{81}$ Id., p. 1033; emphasis added. 
However, the protestant offered two-way service as well, so the services were identical, and the applicant had to demonstrate that existing service was "inadequate".

The applicant did not have to show that all existing services of this type (including some provided by persons who had not protested) were inadequate. Nor did it have to show that the protestant's services were inadequate "in every square mile of the proposed territory," so long as they were inadequate "within the area generally". ${ }^{82}$ Since the protestant here served only a small portion of the applicant's proposed territory, leaving the rest unserved, the court had no difficulty finding that the existing services were inadequate, and granted the certificate.

This case is useful because it gives some content to the legal standards of "identical" and "inadequate" services, and suggests how these tests might be applied in practice. The case of Pennsylvania Railroad Company vs. Pennsylvania $P U C^{83}$ provides additional content to these criteria. There, the railroad sought to prevent two bus companies from combining to offer a commuter bus service which would follow a route similar to the existing rail service. The court noted the general rule that a certificate should not be granted if existing service is adequate. But it observed that "absolute necessity for the new service is not required, nor is it necessary that the proposed service be indispensable. ${ }^{184}$

The evidence showed that the proposed bus route diverged from the existing rail route at various points. It also showed that buses would offer through service and stop at short intervals, which the railroad did not. The proposed service therefore was not "identical" to the existing one, and no showing of inadequacy was required. The court upheld the commission's grant of a certificate to the bus company, emphasizing that the primary purpose of public service laws is not to establish or protect monopolies but to serve the public interest, and that "no carrier has the right to be guaranteed freedom from competition in the face of a need for additional service. ${ }^{185}$

The rather liberal approach of the court in the Mobilfone case is not unusual in cases involving telecommunications, motor transport, or other utilities without large fixed facilities. The Pennsylvania Railroad case is more noteworthy in this respect because it allowed competition even over the protest of a utility with extensive fixed facilities - a situation in which courts have traditionally denied new entry to avoid the prospect of "ruinous" competition.

This view of competition is now changing rapidly in the electric industry and among state commissions and legislatures (if not yet in the courts), at least as to the generation component of electric supply. Traditional principles announced in these cases may also change as competition in various forms begins to supplant the franchised monopoly paradigm.

\section{Certified Retail Service Territories}

Statutes providing for certified retail service territories typically recite that they are designed to promote the orderly development of retail electric service, avoid wasteful duplication of facilities, and minimize disputes among retail electric suppliers. To that end, they divide a state into geographical areas within which each retail electric supplier is certified to supply service. They generally prohibit other retail suppliers from serving those areas, except by agreement or joint petition among the certificated utilities. ${ }^{86}$ Beyond these common characteristics, the statutes differ in specifics.

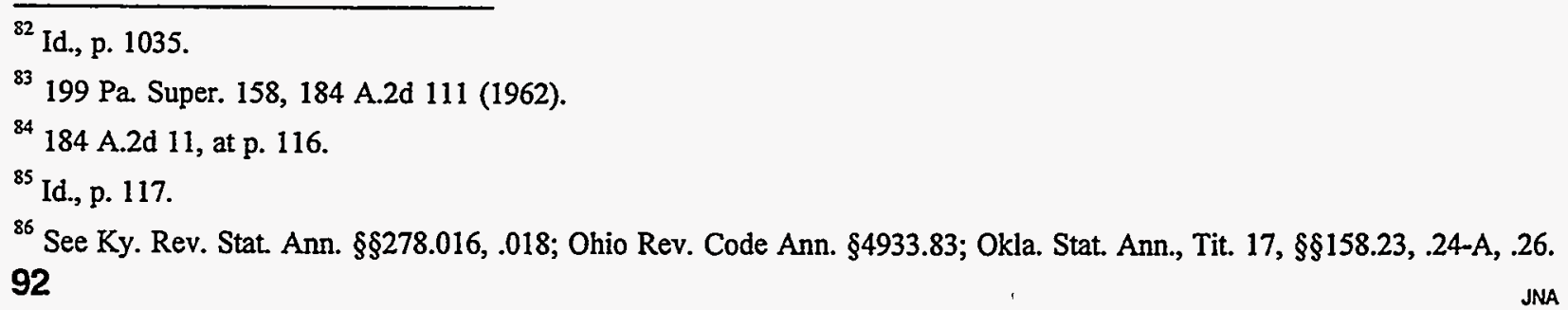


For DR purposes, the most interesting difference is illustrated by the Kentucky and Oklahoma statutes. The heart of both statutes is a provision that reads as follows:

Except as otherwise provided herein, each retail electric supplier shall have the exclusive right to furnish retail electric service to all electric-consuming facilities located within its certified territory, and shall not furnish, make available, render or extend its retail electric service to a consumer for use in electric-consuming facilities located within the certified territory of another retail electric supplier; ... ${ }^{87}$

As noted above in connection with Kentucky's exemption from its independent CPCN requirements, "electric-consuming facilities" means "everything that utilizes electric energy from $a$ central station source." Although neither statute defines "central station source," they clearly suggest that a supplier's exclusive right to furnish retail electric service would not extend to facilities served by other than central station sources - i.e., by DR - nor would the prohibition against furnishing or extending service to other suppliers' territories. In other words, in states with similar retail electric supplier statutes, DR providers would be free to compete for retail customers in certified utility territories (apparently without regard to whether the DR provider is or is not a utility), unless constrained by other provisions of state law. ${ }^{89}$

Service rights under Ohio law do not turn on a limiting definition of "electric consuming facilities". Instead, the statute confers exclusive rights to furnish retail electric service to all "electric load centers" in a certified territory, and prohibits service to such centers in others' territories. Electric load centers essentially mean all electric consuming facilities "of any type or character" at a single location which do or will receive metered service. ${ }^{90}$

Certified retail supplier statutes typically provide opportunities for other suppliers to challenge territorial certifications and for state commissions to reassign territories. Factors to be considered in deciding challenges include which supplier is predominant in the area or was the first to furnish service, the proximity and adequacy of existing distribution lines, and the prevention of duplication." Grounds for territorial reassignment are generally limited to whether the certificated supplier has provided adequate service. ${ }^{92}$

\section{Summary of State Certification Laws}

In many states regulators control entry into markets for utility services by granting or denying certificates of public convenience and necessity, territorial certification, or their functional equivalents. Where these requirements exist, applicants may have to show, among other things, that their proposed facilities or services are needed; that they represent the best and most economic technology choice; that conservation or alternative energy sources cannot cost-effectively meet the need; and/or that the proposed facility or service will not duplicate existing ones.

Such requirements may apply to utilities seeking to add DR to their existing services, since their existing certificates may not be broad enough to cover the new offerings. New entrants proposing to offer services that are "identical" to existing services offered by others typically must demonstrate that the existing services are "inadequate". However, arguments can be made that DR services are not

\footnotetext{
${ }^{87}$ Ky. Rev. Stat. Ann. $\$ 278.018(1)$; Okla. Stat. Ann., Tit. 17, §158.25-A.

${ }^{88}$ Ky. Rev. Stat. Ann. $\$ \S 278.010(8)$; Okla. Stat. Ann., Tit. 17, $\$ 158.22-6$.

${ }^{89}$ Oklahoma's statute limits certified territories to unincorporated areas, and apparently permits extensions to serve new facilities in others' territories if their initial connected load exceeds $1 \mathrm{MW}$ (see 17 Okla. Stat. Ann. §158.25-E).

${ }^{90}$ Ohio Rev. Code Ann. \$4933.81(E),(F), and 4933.83(A).

${ }^{91}$ Ky. Rev. Stat. Ann. $\S \S 278.017(3)$; $\S$ Okla. Stat. Ann., tit. 17, $\S 158.24-C(2)$. Ohio seems to require only that the commission consider proximity and historical obligations to serve; see Ohio Rev. Code Ann. \$4933.82(E).

${ }^{92}$ Ky. Rev. Stat. Ann. $\$ \$ 278.018(3) ; 17$ Okla. Stat. Ann. $\$ \S 158.25-C$; Ohio Rev. Code Ann. $\$ 4933.83(B)$.
} 
identical to other services with which they are likely to compete, and that their introduction in fact would promote important public interests that utility commissions are charged with overseeing.

\subsection{CONCLUSION}

State law will determine whether entities that own, control, manage, and/or operate DR facilities will be treated as public utilities subject to state commission regulatory jurisdiction. State utility laws generally specify what commodities and services are covered; they require service "to the public" to trigger regulatory jurisdiction; and they establish exemptions for specified resources and service configurations. Statutory, administrative and judicial definitions on each of these subjects vary considerably from state to state. Such variations often determine whether those who engage in DR activities will or will not be subject to the burdens and benefits of public utility regulation. State law sometimes affords considerable flexibility to structure DR projects in ways that either invite or avoid regulation (for example, through the choice of resources and/or customers, the scope of distribution, the nature of contractual arrangements between the supplier and its customers, etc.) For this reason, it is important to carefully analyze individual state laws governing specific DR facilities and service configurations to ensure the desired outcome in particular cases.

State siting and certification laws also have the potential to impact DR development options. This research suggests that in fact state siting laws often will not apply to DR projects, because many such projects will fall below the size threshold to which the laws apply. State certification laws appear more varied in their nature and application and, like the public utility definitions and exemptions just discussed, must be analyzed case by case to gauge their impact on DR development. Where they apply, they can either support DR development (where, for example, they establish alternative energy preferences), or hinder it (as where they require a strict showing of need and inadequacy of existing services). They can also have a less direct, but no less important, impact on DR projects by providing a forum for competitive challenges and delay: even where DR projects ultimately can meet certification criteria, the time and cost of establishing that through administrative or judicial proceedings could discourage small projects whose value in some cases depends on timely deployment to capture T\&D or other deferral benefits. Accordingly, this is another area where proactive efforts to streamline certification legislation or implementation procedures could encourage DR implementation. 
The research reported here was intended to begin to define the legal, regulatory and institutional framework within which DR will be developed and deployed. As such, it has surveyed a broad range of topics expected to bear on this subject. Conclusions affecting each of the individual topics surveyed appear throughout the report, and readers are referred to previous sections of the report for those. Overall, however, this phase of the research supports the following conclusions:

- Legal and regulatory factors strongly influence the value of distributed resources, the allocation of benefits flowing from them, and the avenues available to utilities and others to pursue them.

- Unbundling of utility costs and rates resulting from new FERC requirements for nondiscriminatory transmission access and pricing, and from state restructuring proceedings, should enhance the value of DR in many situations and create new DR opportunities.

- Emerging performance-based ratemaking (PBR) can offer stronger incentives for utility distributed resource activities than traditional cost-of-service approaches, but actual impacts will depend on PBR implementation by individual utilities and state commissions.

- Antitrust and anticompetitive considerations will be key considerations for anyone considering DR implementation, and will fundamentally shape the roles' and strategies available to utilities and their affiliates in DR markets.

- Where distributed resource facilities or their owners are subject to utility regulation, it will usually be by state commissions rather than the Federal Energy Regulatory Commission (FERC), unless the facility engages in wholesale electricity sales.

- Most state public utility laws defining entities and activities subject to regulation have not yet been changed to reflect competitive developments in the electric industry, and could result in state regulation of entities pursuing DR activities that are arguably competitive.

- Many distributed resource applications are below the size threshold for state facility siting laws, but may well be affected by laws requiring certification of utility facilities and services.

Of the topics surveyed, antitrust and anticompetitive considerations stand out as especially critical to utility participation in DR activities, and by extension, to the participation of other entities likely to compete in markets for DR products and services. As the report indicates, legal and regulatory principles in this area have been well developed in analogous situations involving electric utility activities alleged to be beyond the monopoly franchise, and even more so in telecommunications litigation and legislation. These proceedings have often sought to balance the costs and benefits of utility participation in arguably competitive markets, and have usually done so through some form of separation requirement. For DR development, it will be worth the effort to craft creative mechanisms through which utilities can bring experience, expertise and efficiencies to the creation of new markets without unfairly using monopoly assets in the process.

Another major area that emerged from the research as especially important is the prospect of unbundling utility costs and rates, and the impact that process is likely to have on the value of DR to utilities and energy customers. To the extent that unbundling leads to disaggregation of costs and prices that reveal the true cost of serving customers, it introduces new ways of valuing DR - not only for its contribution to savings on the utility grid, but for its value to customers relative to the costs they are likely to pay in for service in truly competitive markets. 
A third finding worthy of mention is the possible tension between antitrust doctrines that tend to require separation of monopoly and competitive activities, and traditional state laws developed in other contexts that could have the effect of imposing utility regulation on activities that many would consider competitive. It is important to stress again that these laws remain in force in most states, and will continue to govern until they are changed. Despite widespread interest in competition and restructuring at the state commission level, most state legislatures have yet to act in this area.

Given the intent of this survey phase, the findings and conclusions suggested here and throughout the report are necessarily general in nature, and should be applied only with great caution to individual situations. However, they hopefully can provide a starting point for specific analysis that focuses on individual regulatory and business conditions. That is the next step for those interested in pursuing DR business strategies, and one that requires a different level of focus and a much more detailed review of individual circumstances. To assist in beginning that effort, the report concludes by summarizing the relevance and importance of the various topics reviewed here for DR decisions.

Table 5. Summary of Key Legal \& Regulatory Topics \& Their Importance For Dr

\begin{tabular}{|c|c|c|c|}
\hline TOPIC & ODESCRIPTION & RELEVANCE & IMPORTANCE \\
\hline $\begin{array}{c}\text { Antitrust \& } \\
\text { anticompetitive } \\
\text { principles } \\
\text { applied to utility DR } \\
\text { activities }\end{array}$ & $\begin{array}{l}\text { Protection against } \\
\text { monopoly subsidies of } \\
\text { competitive activities to the } \\
\text { detriment of ratepayers \& } \\
\text { competitors, \& against } \\
\text { other market power abuses }\end{array}$ & $\begin{array}{l}\text { Can preclude competitive } \\
\text { DR activities by utilities, or } \\
\text { require partial or complete } \\
\text { separation of monopoly \& } \\
\text { competitive activities at } \\
\text { some potential cost in } \\
\text { efficiency \& innovation }\end{array}$ & $\begin{array}{c}\text { Very high } \\
\text { for both utilities } \\
\text { \& potential DR competitors }\end{array}$ \\
\hline $\begin{array}{l}\text { Unbundling } \\
\text { of costs \& rates } \\
\text { under FERC open } \\
\text { access \& state } \\
\text { restructuring }\end{array}$ & $\begin{array}{l}\text { Separation of utility costs } \\
\text { into generation, } \\
\text { transmission, \& distribution, } \\
\text { \& customer charges based } \\
\text { on actual (area- \& time- } \\
\text { specific) marginal costs }\end{array}$ & $\begin{array}{c}\text { Identifies high cost areas \& } \\
\text { permits larger DR } \\
\text { investments to be cost- } \\
\text { effective in selected areas }\end{array}$ & $\begin{array}{l}\text { Potentially very high } \\
\text { if full cost \& rate unbundling } \\
\text { occurs at the retail level \& } \\
\text { both are differentiated by } \\
\text { area \& time }\end{array}$ \\
\hline $\begin{array}{l}\text { State public utility } \\
\text { definitions \& } \\
\text { exemptions } \\
\text { applied to DR facilities } \\
\text { \& services }\end{array}$ & $\begin{array}{l}\text { Define commodities, } \\
\text { services, and interests } \\
\text { subject to regulation, \& } \\
\text { exempt specified resources } \\
\text { \& service configurations }\end{array}$ & $\begin{array}{l}\text { Determines whether DR } \\
\text { facilities and their owners or } \\
\text { operators will be regulated } \\
\text { as public utilities \& entitled } \\
\text { to public utility protections }\end{array}$ & $\begin{array}{c}\text { High } \\
\text { for both utilities } \\
\text { \& potential DR competitors }\end{array}$ \\
\hline $\begin{array}{c}\text { State certification } \\
\text { laws }\end{array}$ & $\begin{array}{l}\text { Grant exclusive franchises } \\
\text { for geographic areas } \\
\text { \& prohibit entry by others }\end{array}$ & $\begin{array}{l}\text { Determine whether DR } \\
\text { facilities can be built \&/or } \\
\text { service furnished in } \\
\text { particular geographic area }\end{array}$ & $\begin{array}{c}\text { High } \\
\text { for both utilities } \\
\text { \& potential DR competitors }\end{array}$ \\
\hline $\begin{array}{l}\text { Federal vs. state } \\
\text { jurisdictional } \\
\text { issues }\end{array}$ & $\begin{array}{l}\text { Establish boundaries } \\
\text { between FERC \& State } \\
\text { legislative \& commission } \\
\text { authority over generation, } \\
\text { transmission, } \\
\text { \& local distribution }\end{array}$ & $\begin{array}{c}\text { Determine whether FERC or } \\
\text { state legislatures \& utility } \\
\text { commissions regulate } \\
\text { DR facilities \& their owners } \\
\text { \& operators, } \\
\text { \& what rules apply }\end{array}$ & $\begin{array}{c}\text { Moderate } \\
\text { for both utilities \& potential } \\
\text { DR competitors }\end{array}$ \\
\hline $\begin{array}{l}\text { Performance- } \\
\text { based ratemaking } \\
\text { applied to utility DR } \\
\text { activities }\end{array}$ & $\begin{array}{l}\text { Bases utility rates on } \\
\text { performance relative to pre- } \\
\text { established targets, instead } \\
\text { of on utility cost of service }\end{array}$ & $\begin{array}{l}\text { Establishes incentive } \\
\text { structures that reward } \\
\text { efficiency, productivity \& } \\
\text { cost reduction instead of } \\
\text { capital investment per se }\end{array}$ & $\begin{array}{c}\text { Uncertain } \\
\text { because not yet adopted by } \\
\text { many regulators \& depends } \\
\text { on specific incentives } \\
\text { adopted }\end{array}$ \\
\hline $\begin{array}{c}\text { State siting laws } \\
\text { applied to DR facilities } \\
\text { \& services }\end{array}$ & $\begin{array}{l}\text { Require advance approval } \\
\text { to build energy facilities; }\end{array}$ & $\begin{array}{l}\text { Determine whether } \mathrm{DR} \\
\text { facilities can be built }\end{array}$ & $\begin{array}{l}\text { Low } \\
\text { because DR are usually } \\
\text { below size threshold }\end{array}$ \\
\hline
\end{tabular}




.

•

, 
